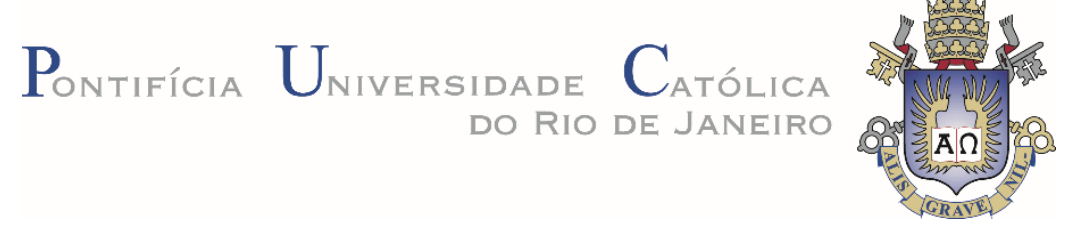

Filipe Teixeira de Freitas e Silva

Desenvolvimento e Avaliação
Experimental de um Motor a
Combustão Interna Rotativo

Dissertação de Mestrado

Dissertação apresentada como requisito parcial para obtenção de grau de Mestre pelo Programa de Pós-Graduação em Engenharia Mecânica da PUC-Rio.

Orientador: Prof. Sergio Leal Braga Coorientador: Prof. José Alberto dos Reis Parise 
Filipe Teixeira de Freitas e Silva

\section{Desenvolvimento e Avaliação Experimental de um Motor a Combustão Interna Rotativo}

Dissertação apresentada como requisito parcial para obtenção do grau de Mestre pelo Programa de PósGraduação em Engenharia Mecânica do Centro Técnico Científico da PUC-Rio. Aprovada pela Comissão Examinadora abaixo assinada.

Prof. Sergio Leal Braga

Orientador

Departamento de Engenharia Mecânica - PUC-Rio

Prof. José Alberto dos Reis Parise

Coorientador

Departamento de Engenharia Mecânica - PUC-Rio

Prof. Sergio Libanio de Campos

Curso Técnico de Engenharia Automobilística - CEFET/RJ

Prof Alexandre Zuquete Guarato

Faculdade de Engenharia Mecânica - UFU

Prof. Márcio da Silveira Carvalho Coordenador Setorial do Centro Técnico Científico - PUC-Rio

Rio de Janeiro, 27 de Fevereiro de 2018 
Todos os direitos reservados. É proibida a reprodução total ou parcial do trabalho sem autorização da universidade, do autor e do orientador.

Filipe Teixeira de Freitas e Silva

Graduou-se em Engenharia Mecânica na PUC-Rio (Pontifícia Universidade Católica do Rio de Janeiro) em 2014. Participou da equipe de desenvolvimento do motor rotativo Kopelrot.

Ficha Catalográfica
1. Engenharia Mecânica - Teses. 2. Motor rotativo. 3. Taxa de compressão variável. 4. Acionamento externo. 5. Eficiência volumétrica. 6. Potência de atrito. I. Braga, Sergio Leal. II. Parise, Jose Alberto dos Reis. III. Pontifícia Universidade Católica do Rio de Janeiro. Departamento de Engenharia Mecânica. IV. Título.


Para meus pais, Heloisa e Andre, Pelo apoio e dedicação. 


\section{Agradecimentos}

Aos meus orientadores, Sergio Leal Braga e José Alberto dos Reis Parise, pelo apoio e confiança em mim depositada.

À CAPES e à PUC-Rio, pelos auxílios concedidos, sem os quais este trabalho não poderia ter sido realizado

À minha família pelo apoio, dedicação e compreensão

Aos meus amigos Guilherme Galvan, Mateus, Aruã, Ellen, Ricardo, Thayon, Marina, I Tsan, Alexandre. Em especial ao Guilherme Fonseca, que me acudiu quando precisei transportar o motor.

Ao Paulo pelo apoio crucial na usinagem de correção de todas as peças, e contribuições para o projeto

Ao Alexandre Guarato pela condução e apoio no projeto do motor Kopelrot.

Ao Julio Kopelowicz, inventor do motor, pela sua contribuição prática e experimental dessa incrível invenção

Ao Pedro Paulo pela compreensão e apoio

À equipe do LEV pelo apoio no preparo da bancada experimental, Zegarra, Jorge, Gerson e Severino.

À Severino pela ajuda fundamental com a aquisição de dados e confecção do programa e interface utilizado na avaliação experimental do motor.

Aos alunos de iniciação científica, Matheus, Leonardo Cristiano e Nicolas pela participação no projeto. 


\section{Resumo}

Silva, Filipe Teixeira de Freitas; Braga, Sergio Leal; Parise, José Alberto dos Reis. Desenvolvimento e Avaliação Experimental de um Motor a Combustão Interna Rotativo. Rio de Janeiro, 2018. 106p, Dissertação de Mestrado - Departamento de Engenharia Mecânica, Pontifícia Universidade Católica do Rio de Janeiro.

No presente trabalho foi realizada a construção, montagem, revisão de projeto e avaliação experimental preliminar de um novo motor a combustão interna rotativo por ignição por centelha, que pode ser classificado como "cat-and-mouse engine" ou "Twin-Rotor Piston Engine". Nesse motor, dois pares de deslocadores são montados sobre dois rotores, que giram em velocidade variável em dentro de uma câmara cilindrica, de forma a conferir uma variação da posição angular relativa entre deslocadores e, assim, formar quatro câmaras de volumes variáveis com o tempo, a fim de se realizar processos termodinâmicos equivalentes aos de um motor alternativo de quatro tempos. Esse motor destaca-se por possuir um sistema inovador que permite a mudança do movimento dos rotores e deslocadores, de forma a aumentar o volume deslocado e a taxa de compressão das câmaras onde ocorrem os processos termodinâmicos. Tal dispositivo permite alterar e otimizar a taxa de compressão para diferentes combustíveis. Os componentes do motor foram usinados de acordo com o projeto e o protótipo foi montado, revisado e ajustado, de forma a garantir a operacionalidade do equipamento. Posteriormente, o motor foi montado em uma bancada para se efetuar testes preliminares de acionamento externo, afim de se medir vazão volumétrica, potência fornecida e pressão de compressão no ponto morto superior em função da velocidade angular. A revisão bibliográfica do trabalho contém definições úteis na classificação de motores rotativos, além de discutir suas especificidades características.

\section{Palavras-chave}

Motor Rotativo; Taxa de compressão variável; acionamento externo; eficiência volumétrica; potência de atrito. 


\section{Abstract}

Silva, Filipe Teixeira de Freitas; Braga, Sergio Leal (Advisor); Parise, José Alberto dos Reis (Co-Advisor). Development and experimental evaluation of a Rotary Internal Combustion Engine, Rio de Janeiro, 2018. 106p, Dissertação de Mestrado - Departamento de Engenharia Mecânica, Pontifícia Universidade Católica do Rio de Janeiro.

The present work describes the construction, assembly, project revision and preliminary experimental evaluation of an innovative rotary spark ignition internal combustion engine. First, a literature survey was carried out. Some useful definitions were found for rotary engines classification as well as some of their specific characteristics were discussed. The engine can be classified as "cat-andmouse" engine or "Twin-Rotor Piston Engine". It is characterized by two pairs of displacers, assembled over two rotors, which rotate at a variable rotational speed within a cylindrical cavity. The driving mechanism is such that the relative distance between each pair of displacers varies continuously, thus providing the positive displacement effect. Therefore, the engine has four chambers, each one with its own time varying volume, so that thermodynamic processes, equivalent to those of a four-stroke reciprocating internal combustion engine, can take place. This engine presents a unique and innovative mechanism by which the compression ratio can be varied during operation, thus optimizing engine efficiency a for a given fuel. Engine components, designed in an effort previous to the present one, were fabricated according to the original project. A prototype was assembled, with all components following a routine of project revision, including measurements, uncertainties and adjustments. The engine was then placed on a test bench where preliminary non-firing external driving tests were carried out. They included: volumetric flow rate, driving (frictional) power and cylinder maximum pressure with displacer at the top dead center, all these parameters in terms of the primary shaft angular velocity.

\section{Keywords}

Rotary engine; variable compression ratio; external driving; frictional power, volumetric efficiency. 


\section{Sumário}

1 Introdução 19

1.1. Motivação 19

1.2. Objetivo 20

1.3. Revisão Bibliográfica 20

1.3.1. Breve histórico sobre motores 21

1.3.2. Definições úteis 23

1.3.3. Evolução 25

1.3.4. Wankel 26

1.3.5. Outros Motores Rotativos 34

1.3.5.1. Motor rotativo de rotor articulado 35

$\begin{array}{ll}\text { 1.3.5.2. Orbital Sarich } & 37\end{array}$

1.3.5.3. Roundengine ou VGT 39

1.3.5.4. Rotatorque 40

1.3.5.5. Cooley, Umpleby e Liquidpiston 41

1.3.6. Motor de pistões rotativos de eixos concêntricos 42

1.3.6.1. Princípio de funcionamento dos motores TRPE 43

1.3.6.2. História e desenvolvimento 46

1.3.7. Evolução do Motor Kopelrot 51

1.4. Informações adicionais sobre motores rotativos 53

1.5. Conclusões a respeito da revisão bibliográfica 53

1.6. Estrutura do Trabalho 54

2 Descrição do Motor Kopelrot 55

2.1. Divisão em módulos do motor Kopelrot 55

2.2. Mecanismo de Acionamento de Velocidade Diferencial DVDM 57

2.2.1. Componentes do DVDM 57

2.2.2. Princípio de funcionamento do DVDM 60

2.3. Sistema de Conversão de Energia (ECS) 67

2.3.1. Componentes do ECS 67

2.3.2. Princípio de funcionamento do ECS 69 
2.3.3. Características da câmara 70

2.3.4. Movimento dos pistões e processos termodinâmicos 71

2.3.5. Segmentos de Vedação 74

2.3.6. Circuito de óleo de arrefecimento 75

2.4. Sustentação do motor $\quad 77$

2.5. Sistema de variação da taxa de compressão 78

2.6. Ajuste de posição da engrenagem solar 80

2.7. Ciclo Atkinson / Miller 80

2.8. Comentários sobre o motor Kopelrot 82

3 Desenvolvimento do Projeto e Montagem 83

3.1. Introdução à montagem do motor 83

3.2. Projeto do motor Kopelrot 83

3.3. Revisão de projeto, montagem, fabricação e ajustes 83

4 Experimento e Resultados $\quad 88$

4.1. Aparato experimental 88

4.1.1. Acionamento externo $\quad 89$

4.1.2. Instrumentação 90

4.2. Planejamento 92

4.2.1. Dos ensaios 92

4.2.2. Redução de dados 92

4.3. Resultados 94

4.3.1. Torque e Potência $\quad 94$

4.3.2. Eficiências Volumétricas 95

4.4. Imprevistos experimentais 95

5 Conclusões e propostas $\quad 97$

5.1. Conclusões sobre o que foi feito 97

5.2. Propostas de alteração para o presente protótipo 98

5.2.1. Sistema de vedação 98

5.2.2. Suporte e rolamento dos rotores 98

5.2.3. Suporte para rolamento axial do eixo de saída 99

5.3. Propostas para os próximos protótipos 99 
5.3.1. Dos rolamentos utilizados

5.3.2. Dos ajustes de montagem

5.3.3. Dos mancais suportes e bases

5.3.4. Da Posição da ignição e janelas de admissão e exaustão

101

5.4. Propostas para os próximos trabalhos

101

5.5. Próximos passos

102

5. Referências bibliográficas 


\section{Lista de Figuras}

Figura 1-1 A esquerda a bomba d'água de Ramelli. No centro uma versão da mesma bomba com várias paletas, e a direita a máquina rotativa de Wittig. (Imagem retirada de Rotary Piston Machines, (Wankel, 1965).

Figura 1-2 Motor Wankel (figura retirada do Internal Combustion Engine Fundamentals, de (Heywood, 1988))

Figura 1-3 Motor Wankel (imagem tirada do Rotary Engines, (Yamamoto, 1971))

Figura 1-4 (esq) Selos de Vedação, (dir) selos de óleo.

limagens de Rotary Engines (Yamamoto, 1971)

Figura 1-5 (esq) motor com aquecimento da região próxima a admissão pelos gases de exaustão, (dir) motor sem aquecimento. Retirado de Rotary Engine (Yamamoto, 1971).

Figura1-6 Razão superfície/volume do motor Wankel (linha contínua) e motor alternativo (linha tracejada). (retirado de Rotary Engine, de Kenichi Yamamoto, 1971).

Figura1-7 Concentração de HC na janela de exaustão em função do ângulo do eixo de manivela, (retirado de Rotary Engine (Yamamoto, 1971).

Figura 1-8 Esquema do motor rotativo quadrilateral (Al Hawaj, 2015))

Figura 1-9 Interior do motor quadrilateral acionado por pressão de vapor (Saint-Hilarie, 2007)

Figura 1-10 llustração da patente do motor Orbital Sarich.

Figura 1-11 llustração do motor VGT ou Roundengine. À esq. imagem retirada de (Karim \& Shrestha et al., 2000), e à direita uma imagem retirada da webpage do motor Round Engine, atualmente indisponível.

Figura 1-12 Motor Rotatorque (Schönrock) 
Figura 1-13 llustrações dos motores Cooley (Cooley, 1903) Umpleby (Umpleby, 1908) e LiquidPiston (LiquidPiston, 2016)

Figura 1-14 Exemplo de twin-rotor piston engine TRPE na configuração com câmara de formato anular, (Kopelowicz, 2009).

Figura1-15 Funcionamento de um motor Twin-Rotor Piston Engine ou TRPE: (i) início da admissão, (ii) fim da admissão, (iii) combustão, (iv) expansão e (v) fim da exaustão. (imagens do projeto do motor Kopelrot)

Figura1-16 Esquema das câmaras de trabalho de cada um dos seguintes motores: (a) E. Oehlmann, (b) Dewandre,(c) Beck,(d) Sanchez \& Baradat,(e) Bullington, retirado das respectivas patentes (Oehlmann., 1884) (Dewandre, 1910) (Beck, 1910) (Sanchez \& Baradat, 1914) (Bullington, 1924), e (f) a imagem do motor Beck divulgada na revista Flight (Flight, 1909).

Figura1-17 Na parte superior a capa da Popular Science, e abaixo, de cima pra baixo, os esquemas dos motores Kauertz, Tschudi e Virmel, respectivamente retirados do artigo da revista Popular Science, (Norbye, 1967).

Figura 1-18 (sup.) motor MYT de Morgado. (inf.) motor do Yomobile (ё-мобиль) (Zou et al., 2014).

Figura 2-1 Visualização dos módulos do motor Kopelrot. Modelo em software SolidWorks

Figura 2-2 Divisão de módulos do modelo real com a câmara sem as tampas laterais

Figura 2-3 Sistema de Conversão de Energia (ECS). Modelo em software SolidWorks

Figura 2-4 Mecanismo de acionamento de velocidade diferencial (DVDM). Modelo em software SolidWorks

Figura 2-5 Componentes do DVDM. O mancal do volante e o mancal intermediário estão ocultos para facilitar a visualização. Modelo em software SolidWorks 
Figura 2-6 Fluxograma da cadeia de movimento dos componentes do DVDM, considerando acionamento a partir do eixo de saída. OBS: A engrenagem solar é o único componente estático.

Figura 2-7 Curvas epicicloides na parte superior, e na parte inferior uma demonstração da formação de uma curva cadioide a partir do rolamento de um círculo sobre um círculo diretor de mesmo raio.

Figura 2-8 Movimento epicicloide dos braços da planetária (o cardioides desenhados sobre as imagens serve para auxiliar o entendimento).

Figura 2-9 Movimento do mecanismo de acionamento de velocidade diferencial para meia volta do volante.

Figura 2-10 Ampliação do conjunto braço planetária, bela e braço de transição.

Figura 2-11 ECS em vista explodida. Modelo em software SolidWorks

Figura 2-12 ECS em vista de corte. Modelo em software SolidWorks

Figura 2-13 (1) Pistões, (2) rotor interno, (3) rotor externo, (4) tampa interna B, (5) cilindro da câmara, (6) tampa intermediária B e (7) tampa externa B, montados sobre bancada.

Figura 2-14 Cilindro da câmara com tampa interna $A$ e tampa intermediária A sem pistões e rotores.

Figura 2-15 Início da admissão da câmara selecionada. Modelo em software SolidWorks

Figura 2-16 Final da admissão e início da compressão da câmara selecionada. Modelo em software SolidWorks

Figura 2-17 Final da compressão, combustão e início da expansão da câmara selecionada. Modelo em software SolidWorks

Figura 2-18 Final da expansão e início da exaustão da câmara selecionada. Modelo em software SolidWorks 
Figura 2-19 Gráfico do movimento entre dois pistões adjacentes P1 e P2 (Guarato et al., 2016).

Figura 2-20 Exemplo de uma linha de vedação do pistão. (esq.) ao lado dos 4 segmentos de vedação e suas molas. (dir.) Vista de corte do pistão, em modelo SolidWorks, com destaque para a posição de montagem dos segmentos de vedação.

Figura 2-21 Passagem de óleo interna pelos rotores. Modelo em software SolidWorks

Figura 2-22 Passagem de óleo interna por um dos pistões.

Modelo em software SolidWorks

Figura 2-23 Tampas de óleo pinadas para aumentar a superfície de troca de calor. Modelo em software SolidWorks

Figura 2-24 Circuito externo de óleo. Modelo em software SolidWorks

Figura 2-25 Sustentação do motor: 1-Base, 2-Suporte das

Bases, 3-Trava,4-Base da Câmara, 5-Suporte da Câmara (incluído no ECS)

Figura 2-26 Taxa de compressão variável: (esq.) rc= 8,2 e (dir.) $\mathrm{rC}=41$,99. (Guarato et al., 2016).

Figura 2-27 Ganho de eficiência térmica do ciclo Miller em relação ao ciclo Otto em função da compressão, de 0,3 = 30\% de compressão a $1=100 \%$ de compressão (ciclo Otto) (Guarato et al., 2015)

Figura 2-28 Razão de potência do ciclo Miller sobre Ciclo Otto, em relação a razão entre curso de expansão sobre curso de admissão, (Ticona et al.,2015).

Figura 3-1 Peças no laboratório de São Marcelo (em cima da bancada do lado esquerdo se encontram as bases e mancais já montados)

Figura 3-2 Peças no laboratório de São Marcelo da PUC-Rio

Figura 4-1 Motor montado sobre os coxins (indicado com setas) e bases 
Figura 4-2 Motor elétrico e Inversor de Frequência

Figura 4-3 Motor elétrico acoplado ao eixo do motor Kopelrot

Figura 4-4 Sensor de pressão piezoelétrico e amplificador

Kistler type 5064

Figura 4-5 Placa de aquisição de dados da National NI USB-

6363

Figura 4-6 Circuito de alimentação dos sensores do medidor de vazão

Figura 4-7 Interface do LabVIEW (desenvolvido pelo Laboratório de Engenharia Veicular)

Figura 4-8 Potência / Potência máxima (Pu/Pu max) e Torque / Torque máximo ( $\mathrm{T} / \mathrm{T}$ max) em função da velocidade angular após 600 s de início dos testes 94

Figura 4-9 Eficiências volumétricas 


\section{Lista de Tabelas}

Tabela 1-1 Acordos de licença da NSU até 1971(fragmento retirado do livro Rotary Engine de Yamamoto, 1971).

Tabela 2-1 Variação de excentricidade

Tabela 3-1 Lista de alterações

86

Tabela 3-2 Lista de alterações (continuação) 


\section{Lista de Símbolos}

$r_{c}: \quad$ Taxa de Compressão

$\varphi_{\max }: \quad$ Ângulo máximo entre pistões

$\varphi_{\min }: \quad$ Ângulo mínimo entre pistões

B: $\quad$ Constante específica do medidor de vazão

C: $\quad$ Constante específica do medidor de vazão

DP: $\quad$ Pressão diferencial (inH20)

$\mu_{s t d}$ : Viscosidade padrão do medidor de vazão

$\mu_{f}: \quad$ Viscosidade do fluxo medido

$P_{f}: \quad$ Pressão absoluta medida (inHg)

$P_{s t d}: \quad$ Pressão padrão do medidor de vazão (inHg)

$T_{s t d}: \quad$ Temperatura padrão do medidor de vazão ( $\left.{ }^{\circ} \mathrm{F}\right)$

$T_{f}: \quad$ Temperatura medida no medidor de vazão ( $\left.{ }^{\circ} \mathrm{F}\right)$

CFM: Vazão volumétrica do medidor de vazão $\left(\mathrm{ft}^{3} / \mathrm{min}\right)$

$\eta_{v o l}$ : Eficiência volumétrica do motor Kopelrot (\%)

$Q_{\text {medido }}$ : Vazão volumétrica medida $\left(\mathrm{m}^{3} / \mathrm{h}\right)$

$Q_{\text {teórico }}$ : Vazão volumétrica teórica $\left(\mathrm{m}^{3} / \mathrm{h}\right)$

$V_{d}$ : Volume deslocado $\left(\mathrm{m}^{3}\right)$

$\omega: \quad$ Velocidade angular (RPM)

$P_{u}$ : $\quad$ Potência útil nos eixo do motor elétrico e motor Kopelrot (W)

U : $\quad$ Tensão elétrica de alimentação do motor elétrico $(V)$

I : $\quad$ Corrente elétrica de alimentação do motor elétrico $(A)$

$\tau$ : $\quad$ Torque no eixo do motor elétrico e motor Kopelrot (Nm) 


\section{Abreviações}

DVDM: Diferential Velocity Drive Mechanism - Mecanismo de Acionamento de Velocidade Diferencial

ECS: $\quad$ Energy Conversion System - Sistema de Conversão de Energia

$\mathrm{HCCl}: \quad H o m o g e n e o u s$ Charge Compression Ignition

MYT: $\quad$ Massive Yet Tiny

ORE: $\quad$ Oscilatoy Rotating Piston Engine

PLM: $\quad$ Planetary Rotation Machine

PROM: $\quad$ Rotating Piston Machine, planetary rotation type

QRM: $\quad$ Máquina Rotativa Quadrilateral

RRM: Máquina Rotativa Romboidal

SIM: $\quad$ Single Rotation Machine

SROM: Rotating piston engine, single rotation type

TRPE: $\quad$ Twin Rotor Piston Engine

VGT: Variable Geometry Toroidal Engine

Yo-Mobile: ё-мобиль (O nome original é em cirílico) 


\section{Introdução}

O presente trabalho trata da montagem, projeto e avaliação experimental de um protótipo de um motor rotativo de combustão interna.

O motor em questão, garantido em depósito de patente (Kopelowicz, 2012), apresenta um sistema inovador de variação da razão de compressão, que permite uma otimização da eficiência térmica funcionando com diferentes combustíveis, o que o torna uma alternativa ideal para ser utilizado como um motor "flex".

Além do experimento, foi realizado um amplo estudo dos motores rotativos presentes na literatura, seus princípios de funcionamento e suas soluções para contornar problemas característicos de motores rotativos.

\section{1. Motivação}

A busca por meios de geração de energia mais eficientes é uma questão em constante investigação. Em suas aplicações não estacionárias, como em automóveis, a energia utilizada ainda é, majoritariamente, gerada utilizando-se motores a combustão interna. No entanto, com a descontinuidade da utilização do motor rotativo Wankel pela Mazda, devido a legislações mais restritivas em emissões, apenas motores alternativos são utilizados como motores a combustão interna e, no atual estado da arte, apresentam altas eficiências térmicas com a utilização de novos injetores e turbo compressor e a possibilidade de funcionarem com mais de um combustível. No entanto, em sua maioria, motores multicombustíveis possuem razão de compressão fixa, de forma que não é possível otimizar a eficiência térmica na utilização de cada combustível, e mesmo em alguns modelos onde a razão de compressão é variável, tal variação não é significativa. Assim, em um cenário onde o motor a combustão interna alternativo goza de alta confiabilidade e prestígio, o motor rotativo Kopelrot, com algumas características que superam o motor a pistão, se apresenta como uma alternativa ousada para um motor de combustão interna. 
O motor Kopelrot possui um mecanismo inovador em sua categoria de motores rotativos, que permite a variação de sua razão de compressão dinamicamente (isto é, durante a operação) dentro de uma ampla faixa de valores, variando de uma razão de 8:1 até 40:1. Na prática essa variação significa que o presente motor pode funcionar de forma otimizada para diversos combustíveis e condições de funcionamento. Desta forma, espera-se que possua uma performance superior a motores alternativos convencionais ao utilizar diferentes combustíveis.

Por se tratar de um motor rotativo, espera-se problemas similares a outros motores rotativos, como vazamento, e emissões elevadas. No entanto, a construção do motor Kopelrot permite a montagem de mais níveis de vedação do que o motor Wankel, o que representa uma vantagem adicional.

\section{2.}

\section{Objetivo}

O presente trabalho foi conduzido de forma a avaliar a construção do protótipo e suas dificuldades de fabricação, montagem e funcionamento. O conhecimento adquirido sobre a construção do motor é indispensável para a equipe de projeto e o progresso da pesquisa do motor Kopelrot.

\section{3. \\ Revisão Bibliográfica}

O objeto de estudo do presente trabalho, um motor a combustão rotativo específico, está inserido em um tema abrangente e ao mesmo tempo pouco discutido. $\mathrm{O}$ tema é abrangente pois existem inúmeras configurações de motores rotativos possíveis, e pouco discutido devido a sua baixíssima utilização em escala. No presente momento os motores rotativos possuem baixa relevância, pela descontinuidade da utilização de motores Wankel pela Mazda (Autocar, 2010). Dessa forma, o tema acaba sendo tratado como questão de "curiosidade" quando se observa na literatura científica. Explica-se esse posto de "curiosidade" acadêmica devido ao baixo sucesso que motores rotativos conquistaram ao longo dos anos, em função das inúmeras dificuldades e peculiaridades na operação desses equipamentos. 
O presente trabalho trata desenvolvimento de um protótipo de um motor a combustão interna rotativo. Faz-se necessário, portanto, procurar na literatura o que já foi feito e as soluções de engenharia desenvolvidas para sanar problemas peculiares de motores rotativos.

A revisão bibliográfica é dividida em cinco partes, com a primeira apresentando um breve histórico a respeito do desenvolvimento de motores a combustão interna em geral. Na segunda parte é apresentada a introdução de conceitos fundamentais para a classificação de motores rotativos, de acordo com (Wankel, 1965). Entende-se que tal conhecimento é fundamental para o entendimento sobre o tema. Na terceira parte é feita uma revisão sobre algumas características do motor Wankel, por sua importância e marco tecnológico no tema do presente trabalho. Na quarta parte são apresentados outros motores que atingiram determinado grau de desenvolvimento. Na quinta e última parte é feita uma revisão sobre motores rotativos de eixos concêntricos, em inglês Central-Axis rotating-piston machines, categoria à qual pertence o motor objeto de estudo do presente trabalho.

\subsection{1.}

\section{Breve histórico sobre motores}

Pode-se dizer que o início do desenvolvimento dos motores a combustão interna, na configuração utilizada nos dias atuais, data do século XIX, durante a chamada de "Segunda Revolução Industrial”. Naquele período, várias foram as pesquisas e desenvolvimentos sobre os motores a combustão interna, e com isso várias pessoas se envolveram e de alguma forma contribuíram. Dentre esses vale ressaltar Nicolaus August Otto, quando, em 1876, faz funcionar seu motor de quatro tempos com sistema de biela e manivela (Heywood, 1988). Também temos Rudolf Diesel quando, em 1892 patenteia o motor de ignição por compressão, injetando combustível ao volume de ar, aquecido unicamente pela etapa de compressão. Seu motor também era de movimento alternativo de quatro tempos com biela e manivela (Heywood, 1988). Dentre os inventores desse período, cita-se também James Atkinson, inventor de um motor alternativo a pistão, com um curso de expansão mais longo do que o de compressão, com o objetivo de se conseguir maiores eficiências (Atkinson, 1887). A referência a James Atkinson se faz necessária tendo 
em vista a utilização do ciclo Miller/Atkinson em motores fabricados recentemente (Sheehan, 2016), e também da possibilidade de sua aplicação em motores rotativos, que será explicado nas próximas seções.

A utilização continuada de motores alternativos a pistão até os dias atuais evidencia o sucesso e confiabilidade da utilização de maquinas de deslocamento positivo alternativos em motores a combustão interna, de forma que, somente décadas mais tarde os motores rotativos a combustão começaram a receber uma maior atenção. No universo de configurações de motores rotativos, o motor de Felix Wankel merece destaque. Wankel começa a desenvolver o conceito do seu motor rotativo de quatro tempos, como conhecemos hoje, no período entre guerras, e o patenteia anos mais tarde. É importante frisar que Wankel estudou diversas configurações de máquinas de deslocamento positivo rotativas, para encontrar o candidato ideal na aplicação de um motor a combustão interna de quatro tempos (Wankel, 1965). Devido ao final da Segunda Guerra mundial, grande parte do seu trabalho é perdida ou destruída, e somente na década de 50 o seu motor atinge estágio avançado de desenvolvimento, para então efetuar e divulgar o primeiro teste experimental no ano de 1957, em parceria com a NSU (Wankel, 1965). Nos anos seguintes o seu motor começa a ser fabricado pela empresa alemã NSU, sendo assim o primeiro motor rotativo a conquistar um sucesso comercial significativo em maior escala. Nos anos seguintes, o motor Wankel passa a ser utilizado em diversas montadoras ao redor do mundo (Yamamoto, 1971), como pode ser visto na Tabela $1-1$.

Em 1961, a empresa japonesa Tokyo Kogyo Co (atual Mazda) adquire os direitos de fabricar o motor rotativo Wankel da antiga NSU, e passa a utilizá-lo em diversos automóveis (Yamamoto, 1971). A Mazda continua a utilizar o motor rotativo em seus automóveis, até que em 2010 seu modelo RX-8 falha em passar nas normas de emissões europeias, euro V (Aautocar, 2010), e a fabricação do RX8 é suspensa, terminando, assim, uma era dos motores rotativos.

No final de 2015, a Mazda revela um novo automóvel conceito utilizando motor rotativo e, em 2016, é publicada uma patente que demonstra recentes desenvolvimentos a partir do conceito de motor rotativo para futuros automóveis a serem fabricados pela marca (Beckwith, 2016; Shimizu et al, 2016). Porém, no presente momento, nenhum veículo com motor rotativo de qualquer tipo é fabricado em larga escala. 
Tabela 1-1 Acordos de licença da NSU até 1971(fragmento retirado do livro Rotary Engine (Yamamoto, 1971).

\begin{tabular}{|c|c|c|c|}
\hline Compania & Data & País & Motor \\
\hline Fichtel \& Sachs AG & $12 / 1960$ & \multirow{7}{*}{$\begin{array}{l}\text { Alemanha } \\
\text { Ocidental }\end{array}$} & gasolina \\
\hline Klöckner-Humboldt & 10/1961 & & Diesel \\
\hline Daimler-Benz AG & 10/1961 & & Gasolina e Diesel \\
\hline $\begin{array}{c}\text { MAN (Maschinenfabrik Augsburg } \\
\text { Nürnberg AG) }\end{array}$ & 10/1961 & & Diesel \\
\hline Friedrich Krupp HmbH & 11/1961 & & Diesel \\
\hline Dr. Ing. H.c.F Prsche KG & 03/1965 & & Gasolina \\
\hline Johannes Graupner & 09/1967 & & Gasolina \\
\hline Curtiss-Wright Corp & $10 / 1958$ & \multirow{3}{*}{ E.U.A. } & Todos \\
\hline Outboard Marine Corp. & 03/1966 & & Gasolina \\
\hline General Motors Corp & $11 / 1970$ & & Todos \\
\hline Comotor S.A & 05/1967 & Luxemburgo & $\begin{array}{l}\text { Gasolina multi } \\
\text { combustivel }\end{array}$ \\
\hline Yanmar Diesel Co & 02/1961 & \multirow{4}{*}{ Japão } & Gasolina e Diesel \\
\hline Tokyo Kogyo & 02/1961 & & Gasolina \\
\hline Nissan Motor & $10 / 1970$ & & Gasolina \\
\hline Suzuki Motor & $11 / 1970$ & & Gasolina \\
\hline Alfa Romeo & $04 / 1964$ & Italia & Gasolina \\
\hline Rolls-Royce Limited of Derby & $02 / 1965$ & Inglaterra & $\begin{array}{c}\text { Multi-combustível e } \\
\text { Diesel }\end{array}$ \\
\hline Savkel & $08 / 1969$ & Israel & Gasolina \\
\hline
\end{tabular}

\subsection{2.}

\section{Definições úteis}

O objetivo dos motores da combustão interna é a geração de potência mecânica a partir da energia química dos combustíveis. Nesses motores de deslocamento positivo, o processo de combustão e liberação de calor ocorre dentro do equipamento, em um volume fechado, cercado por paredes sólidas. O trabalho mecânico é gerado a partir da variação de volume da câmara, onde ocorre a combustão e o aumento de pressão, sendo que essa variação de volume somente é possível a partir do movimento de componentes mecânicos, comumente chamados de pistão ou rotor, dependendo da forma do componente (Heywood, 1988; Wankel, 
1965). Tendo em vista essa definição de motores, a presente dissertação não abordará turbinas a gás, nem o motor por ondas de pressão (wave rotor engine), por serem máquinas de fluxo, das quais se obtém trabalho mecânico a partir de um diferente princípio.

Dentre os motores a combustão interna, pode-se separá-los entre o grupo dos motores alternativos, e motores rotativos. Em seu livro (Wankel, 1965), Felix Wankel desenvolve um estudo bastante detalhado a fim de criar uma classificação para maquinas rotativas, em função do movimento do centro de gravidade de seus componentes de transmissão de potência, em inglês power transmiting part. No entanto, essa classificação restringe-se a motores cujos eixos de rotação dos componentes de transmissão de potência estejam paralelos entre si.

Define-se como motor alternativo, qualquer tipo de motor a combustão interna onde o centro de gravidade de seus componentes de transmissão de potência (Pistões), realiza um movimento de ida e volta (Wankel, 1965). A trajetória desenvolvida pelo seu centro de gravidade desenha uma curva aberta, podendo ser uma linha reta ou curva, dependendo da construção do motor. Quando um pistão de seção circular translada dentro de um cilindro (caso mais comum dentre os motores produzidos atualmente), o seu centro de gravidade efetua um trajeto de ida e volta sobre uma linha reta. Já nos casos onde o pistão, também de seção circular, possui um movimento de pêndulo ao redor de um centro fixo (caso muito particular encontrado em máquinas antigas), o pistão efetua um movimento de ida e volta em curva, num espaço que se assemelha a uma seção de um toroide, ao invés de um cilindro, e, consequentemente, o seu centro de gravidade desenvolve uma trajetória de arco circular. Ainda em motores alternativos, também existe a possibilidade de o centro de gravidade do elemento de transmissão de potência ser fixo, quando a construção do motor de algum modo permita que o conjunto acoplado aos pistões oscile sobre si mesmo (Flight, 1909), com mudança no sentido da velocidade angular. É importante observar que nada impede o pistão ser substituído por outro componente de seção transversal não circular. As formas do componente e do espaço por onde ele se desloca seriam diferentes, porém o princípio da análise sobre o trajeto de seu centro de gravidade continuaria o mesmo.

Já os motores rotativos são aqueles cujo centro de gravidade de seus componentes de transmissão de potência, pistão ou rotor, desenvolve um movimento unidirecional, cuja curva da trajetória pode ser circular ou de outro 
formato fechado (Wankel, 1965). Além disso, existe a possibilidade do centro de gravidade dos componentes de transmissão de potência estar fixo (Sanchez \& Baradat, 1914), com as outras peças girando de forma unidirecional ao redor do centro de gravidade. Os componentes podem girar em velocidade constante ou não, desde que mantenham o sentido do movimento. Além disso, assim como foi observado no caso dos motores alternativos, a forma da seção transversal do componente de transmissão de potência não influencia na análise do movimento do seu centro de gravidade.

Essas definições, mesmo que relativamente simples, são importantes para evitar pressuposições equivocadas em torno do tema de motores rotativos. Devido ao grande número de ideias para possíveis conceitos de motores rotativos, que têm surgido a todo o momento desde o início do século XX, pode-se encontrar na literatura referências de supostos motores rotativos, que quando analisados com mais cautela, utilizando como referência a classificação de Wankel (Wankel, 1965), revelam-se motores alternativos verdadeiramente, sendo a principal fonte desse equívoco a forma da câmara de combustão aliada ao movimento pendular dos pistões.

A classificação de máquinas rotativas desenvolvida por Felix Wankel é bastante detalhada, e apresenta diversas subclassificações dentro dos próprios motores rotativos. Então, por conta do acima exposto, as máquinas aqui abordadas apenas virão acompanhadas do seu tipo, de acordo com a classificação, mas a classificação em si não será explicada no presente trabalho. Além disso, é importante não confundir a referência ao Motor Wankel e a classificação de máquinas rotativas de Felix Wankel.

\subsection{3.}

\section{Evolução}

A primeira máquina rotativa de que se tem conhecimento data de 1588 , uma bomba d'água do italiano Ramelli (Norbye, 1971). A variação do volume é feita a partir da rotação de seu rotor interno sobre o próprio centro de gravidade, enquanto que uma paleta plana desliza em um rasgo radial, em um movimento para fora e para dentro de seu rotor. Desta forma, enquanto o rotor gira, a extremidade externa da paleta desliza sobre todo o perímetro da superfície interna no invólucro externo 
do motor. Ao mesmo tempo, a mesma paleta desliza linearmente dentro do rasgo radial do rotor interno. Séculos mais tarde, Wittig desenvolve uma máquina rotativa utilizando o mesmo princípio, só que com várias paletas. Esta solução é até hoje utilizada em compressores e sopradores (Wankel, 1965). Ambas as máquinas são classificadas como internal axis, rotating-piston-machine, planetary-rotation type PROM, Figura 1-1.

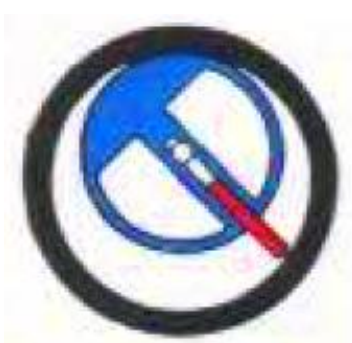

Ramelli 1588

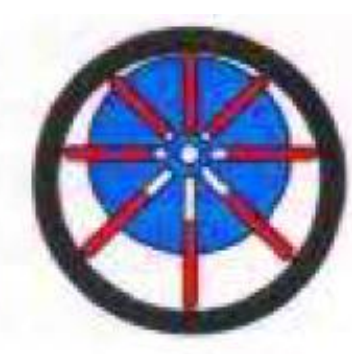

Wittig about 1900

Figura 1-1 A esquerda a bomba d'água de Ramelli. No centro uma versão da mesma bomba com várias paletas, e a direita a máquina rotativa de Wittig. (Imagem retirada de Rotary Piston Machines, (Wankel, 1965).

Máquinas rotativas vêm sendo amplamente utilizadas como compressores, sopradores e bombas d'água, com sucesso significativo. No entanto, o processo de combustão interna apresenta novos desafios, que dificultam a adaptação de máquinas de deslocamento positivo rotativas em motores a combustão interna e, até o presente momento, o único motor rotativo a obter sucesso foi o motor Wankel.

Dentre as dificuldades da construção de motores rotativos, é um consenso a dificuldade de se garantir uma boa vedação da câmara de combustão em altas pressões, além da distribuição não uniforme da temperatura nas paredes do motor. Além da vedação, a lubrificação e resfriamento também são pontos importantes no funcionamento do motor.

\subsection{4.}

Wankel

O princípio de funcionamento do motor Wankel consiste em um rotor central, que é o componente responsável pela transmissão de potência para o eixo do motor, se movimentando no interior do bloco do motor cuja superfície interna forma um epitrocoide (Figura 1-2, Figura 1-3). O rotor, de forma geométrica formada por três 
flancos, gira em volta de seu centro de gravidade que, por sua vez, gira ao redor eixo de saída do motor, de forma a sempre manter seus vértices, ou ápices (apex), em contato com as paredes internas do invólucro do bloco do motor. De acordo com a classificação de máquinas rotativas, o motor Wankel enquadra-se no tipo na categoria de parallel internal axis, Planetary Rotation Machine PLM, Slip engagement, com selo de vedação acoplado ao elemento interno, com relação de velocidades 2:3.

$\mathrm{Na}$ parte interna dos rotores (motores Wankel podem possuir vários rotores em paralelo), passa um eixo excêntrico, sobre o qual é transmitida a potência para o eixo de saída do motor, (Figura 1-2). A relação de velocidade entre o rotor e o eixo de saída é de 3:1, isto é, a cada três voltas do eixo excêntrico, o rotor completa uma revolução inteira. Os volumes entre o rotor e o bloco formam as três câmaras de volume variável, necessárias para a realização do ciclo de quatro tempos do motor. Nos flancos periféricos do rotor, três no total, existem recessos com o objetivo de não dividir a câmara de combustão no ponto morto superior do motor. Esses rebaixos estão presentes nos três flancos do rotor (Yamamoto, 1971) e podem ser observados na (Figura 1-4).

Nos vértices do rotor existem selos de vedação, chamados de Apex seal, responsáveis pela estanqueidade entre as câmaras de combustão nos flancos do rotor (Figura 1-4). Além disso, a posição e geometria dos Apex seals e os selos de vedação laterais do rotor definem a posição das portas de admissão e exaustão, pois como o tempo de abertura das portas depende da geometria e posição angular do rotor, em função das formas e posições, é possível haver "cruzamento da admissão com a exaustão", quando a porta de admissão possui passagem direta para a porta de exaustão. Nos motores reciprocantes, o cruzamento de válvulas acontece quando, ao final da exaustão dos gases, e início da admissão, as válvulas de admissão e escape ficam simultaneamente abertas durante um breve intervalo de tempo. No entanto, no motor Wankel, esse cruzamento depende da configuração da portas de admissão e de exaustão.

As portas de admissão podem ser localizadas na periferia do bloco do motor, ou em suas laterais. As portas laterais possuem a vantagem de poder capturar o blow-by gas que possa a vir vazar para o espaço entre os selos laterais e o selo de óleo. Já a porta de exaustão é sempre localizada na periferia do motor. Deve-se lembrar que a posição, e o formato dessas portas, dependem dos selos de vedação 
do rotor (Yamamoto, 1971). Na (Figura 1-4) pode-se observar a construção dos selos de vedação e os selos de óleo. Os gases de blow-by se alojam no espaço entre o selo de vedação lateral e o selo de óleo, para então escoar para a porta de admissão, caso exista uma porta de admissão na lateral do motor.

Dentro das paredes externas do bloco do motor existem canais, por onde passa o fluido do sistema de resfriamento do bloco do motor. Já o rotor é resfriado por óleo lubrificante, que é bombeado para dentro do rotor através do eixo excêntrico. Nesses motores, existe a necessidade a utilização de um radiador para resfriar o óleo utilizado no arrefecimento do motor, tendo em vista que o aumento da temperatura do óleo lubrificante acelera sua degradação, e o faz perder propriedades importantes para o resfriamento e lubrificação do motor. Desta forma o óleo deve ser mantido em uma faixa de temperatura entre $70{ }^{\circ} \mathrm{C}$ e $90{ }^{\circ} \mathrm{C}$.

Existem também os modelos resfriados a ar, onde o arrefecimento do rotor é feito pela mistura de admissão, que passa por dentro do rotor antes de efetivamente entrar na câmara de combustão. O motor resfriado a ar é menos eficiente, devido ao longo trajeto na admissão e o aquecimento da mistura admitida mas, em compensação, é mais compacto e de menor custo de fabricação. Dessa forma, o resfriamento a ar é mais utilizada em motores menores (Yamamoto, 1971).

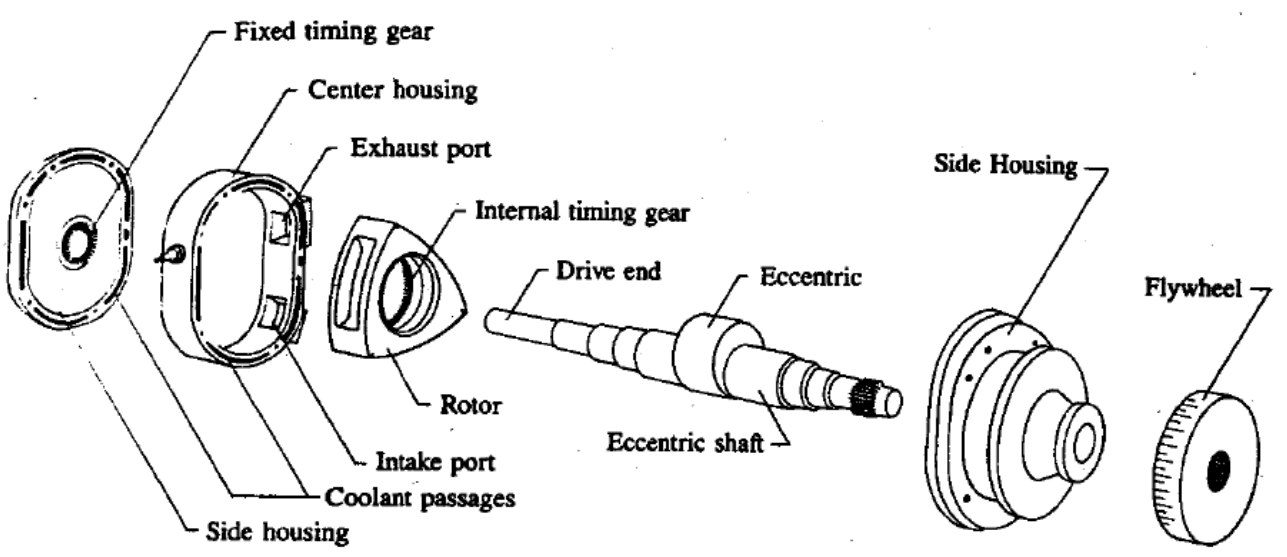

Figura 1-2 Motor Wankel (figura retirada do Internal Combustion Engine Fundamentals, de (Heywood, 1988))

Mesmo em motores rotativos com sistema de resfriamento, é comum haver problemas de distribuição desigual de temperatura no bloco do motor. Em algumas máquinas rotativas, o local onde ocorre a combustão não é o mesmo onde ocorre a admissão, como é o caso dos alternativos. Dessa forma existe uma região de alta 
temperatura próxima à região da combustão, e outras regiões de temperaturas menores, próximas à admissão e exaustão. Essa distribuição não uniforme de temperatura pode causar diversos efeitos, como tensões nos componentes do bloco do motor e, principalmente, deformações dessas paredes, que alteram a geometria interna do bloco do motor, o que afeta diretamente na capacidade vedação e o bom funcionamento dos motores rotativos, que são diretamente influenciados pelas folgas do motor.

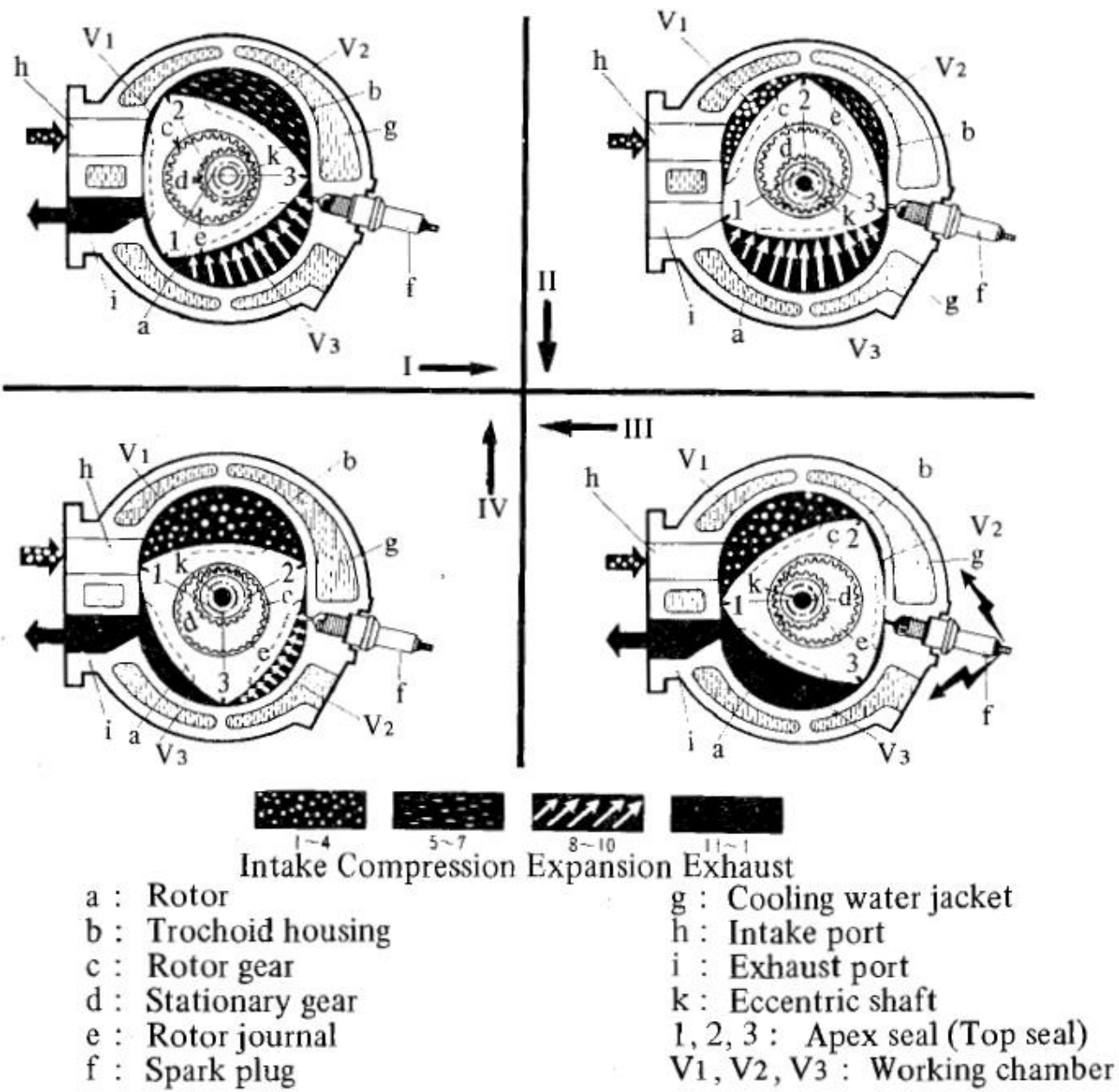

Figura 1-3 Motor Wankel (imagem tirada do Rotary Engines, (Yamamoto, 1971)) 

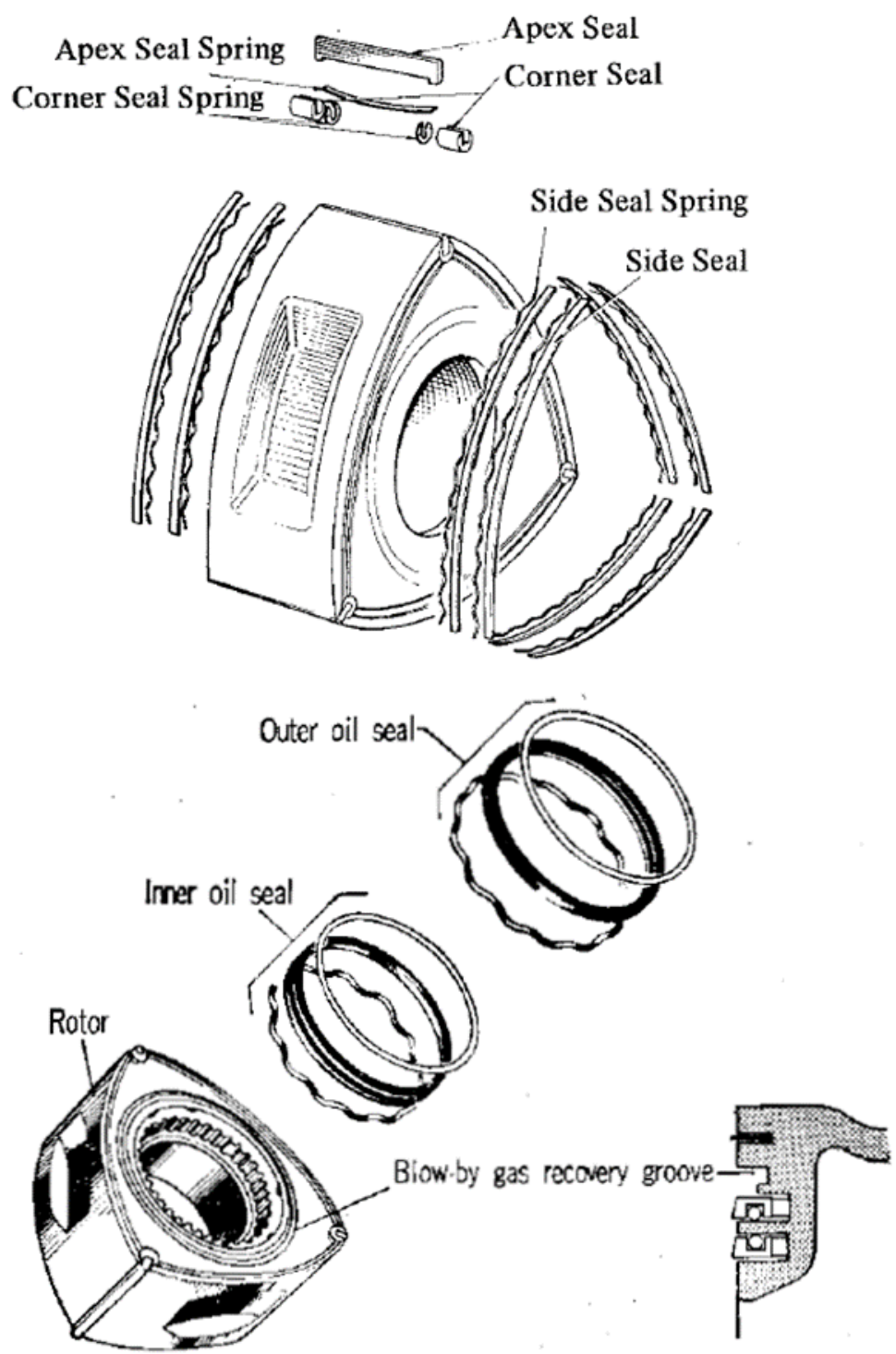

Figura 1-4 (esq) Selos de Vedação, (dir) selos de óleo. Iimagens de Rotary Engines (Yamamoto, 1971)

Existem duas configurações dos arranjos dos canais de arrefecimento, um circunferencial e outro axial. Ambos possuem o objetivo primário de reduzir a temperatura da região aquecida do motor próxima a região da combustão. O sistema também pode utilizar o mesmo fluido de arrefecimento para aquecer as zonas mais frias do motor, no intuito de diminuir as diferenças de temperaturas distribuídas em diferentes regiões pelo bloco do motor. Em alguns casos, parte dos gases da exaustão é utilizada para aquecer as paredes da região próxima à admissão, para reduzir as diferenças de temperatura, e ajudar na vaporização da mistura admitida. A Figura 1-5 mostra a distribuição de temperaturas na superfície periférica do motor, na esquerda com aquecimento da região de admissão e na direita sem 
aquecimento. Pode-se notar que com o sistema de aquecimento reduz-se os gradientes térmicos do bloco do motor.

Outro ponto crítico em motores rotativos é a lubrificação das partes móveis. Em motores Wankel a lubrificação por ser feita de dois modos. O primeiro, que é utilizado em motores mais simples, lubrifica suas partes moveis através da pré mistura do combustível com óleo lubrificante, com o objetivo de simplificar a construção do motor, de forma similar da lubrificação de motores dois tempos. Já nos motores automobilísticos, a lubrificação é feita independentemente da mistura de admissão, de forma controlada e diferenciada para cada condição de funcionamento do motor. Nesses motores, o óleo é utilizado para a lubrificação de mancais do eixo, e dos rotores, e também do sistema de arrefecimento dos rotores, e por conta disso, nas laterais dos rotores, além dos selos de vedação lateral, na parte mais interna existem selos chamados selos de óleo, responsáveis por impedir a passagem de óleo do sistema de arrefecimento e lubrificação diretamente para o espaço por onde fluem blow-by gas para a porta de admissão.

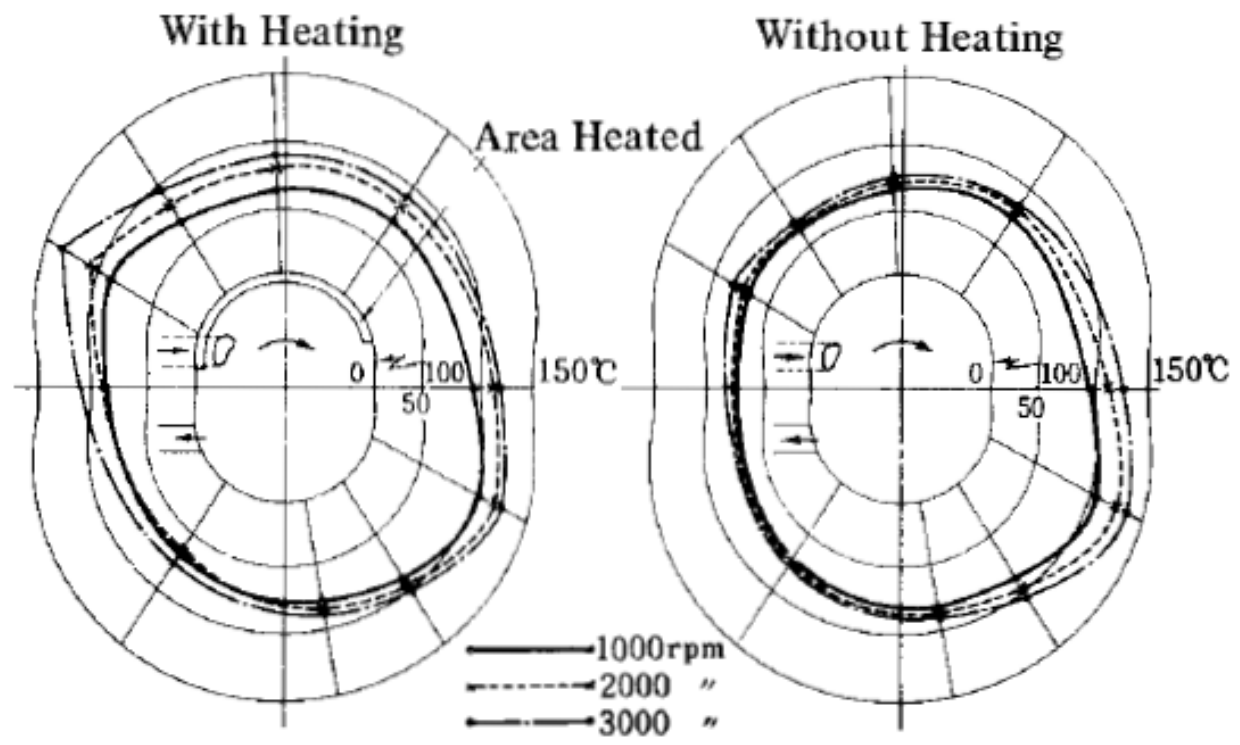

Figura 1-5 (esq) motor com aquecimento da região próxima a admissão pelos gases de exaustão, (dir) motor sem aquecimento. Retirado de Rotary Engine (Yamamoto, 1971).

Além disso, parte do óleo é injetado na mistura, a fim de lubrificar os selos de vedação da câmara de combustão, tanto os Apex seal quanto os selos laterais. Dessa forma, a mistura a ser queimada no motor Wankel possui uma parcela de óleo, mesmo a baixas razões de óleo lubrificante/combustível, variando de 1/150 a 1/250 (Yamamoto, 1971), dependendo das condições de funcionamento do motor. 
A injeção de óleo lubrificante na câmara de combustível, além de ajudar na redução da fricção entre as paredes e os selos, ajuda na vedação entre as câmaras de combustão. Na verdade, a sua principal função dentro da câmara de combustão é formar um filme de óleo e ajudar na vedação do Apex seal que, como foi mencionado anteriormente, representa a única barreira entre câmaras adjacentes.

Com relação a emissões, motores Wankel diferem de motores alternativos principalmente nas emissões de hidrocarbonetos (HC) e óxidos de nitrogênio (NO e $\mathrm{NO}_{2}$ ), enquanto que emissões de $\mathrm{CO}$ e $\mathrm{CO}_{2}$ não representam diferenças significativas.

Os principais mecanismos de emissão de $\mathrm{HC}$ em motores são quatro:

(i) Quando a chama extingue próxima à parede da câmara de combustão,

(ii) Preenchimento das reentrâncias da câmara de combustão, por pequena parcela da mistura admitida, que ausenta-se do processo de combustão, que então escoa para a exaustão como mistura não queimada

(iii) Absorção de vapor de combustível pelas camadas de óleo das paredes da câmara,

(iv) Combustão incompleta ou falha da combustão da mistura (Heywood, 1988).

Tais mecanismos de formação de emissões ocorrem tanto em motores rotativos quanto em alternativos mas, uma vez que os três primeiros itens são diretamente relacionados às paredes da câmara, é de se esperar que quanto maior a razão superfície/volume da câmara de combustão, maiores as emissões produzidas por esses três primeiros itens. Assim é fácil entender o porquê que os motores Wankel produzirem maior emissão de $\mathrm{HC}$ em comparação com os motores alternativos, pois possuem uma maior razão de superfície/volume, como pode ser visto na (Figura1-6). Além disso, a geometria da câmara, na região mais "atrasada" e próxima da segunda vela de ignição, é mais "achatada" nos instantes seguintes a ignição ou seja, apresenta uma maior relação superfície/volume que o resto da câmara. E para complementar, durante os momentos seguintes da combustão, existe um grande escoamento de mistura fluindo dessa parte mais "achatada", retardatária da câmara, para a área mais "larga" e adiantada da câmara, o que faz com que a frente de chama alcance com dificuldade parte da mistura dessa região mais achatada, o que ocasiona uma maior porção de combustível não queimado nessa 
região. Desse modo, a maior parte da mistura não queimada no volume da câmara concentra-se no lado mais atrasado do rotor, o que resulta numa maior emissão de HC ao final do processo de exaustão de cada câmara. Na (Figura1-7) é possível observar que a maior concentração de emissão de $\mathrm{HC}$, durante um processo de exaustão, ocorre no momento do ponto morto superior, quando o volume da câmara é mínimo, instante no qual a última porção de gases da câmara escoa pela porta de exaustão, parcela de gases essa referente a região mais atrasada e "achatada" da câmara.

Surface/volume of reciprocating engine and rotary engine

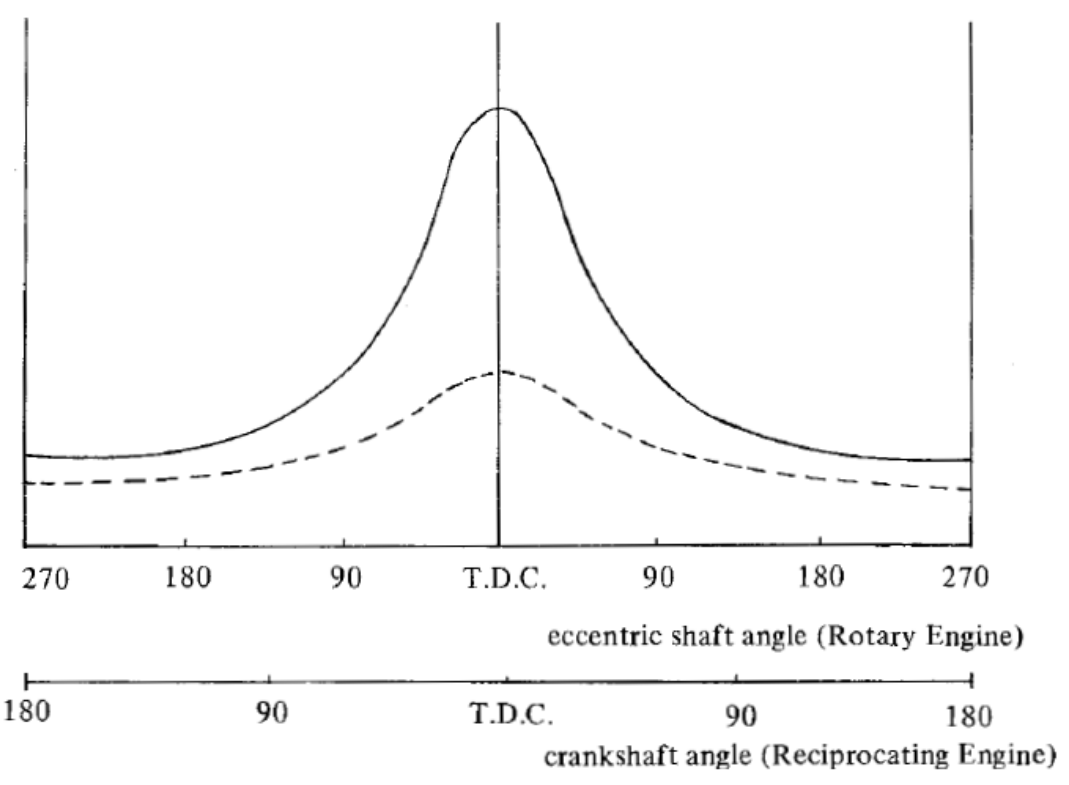

Figura1-6 Razão superfície/volume do motor Wankel (linha contínua) e motor alternativo (linha tracejada). (retirado de Rotary Engine, de Kenichi Yamamoto, 1971). 


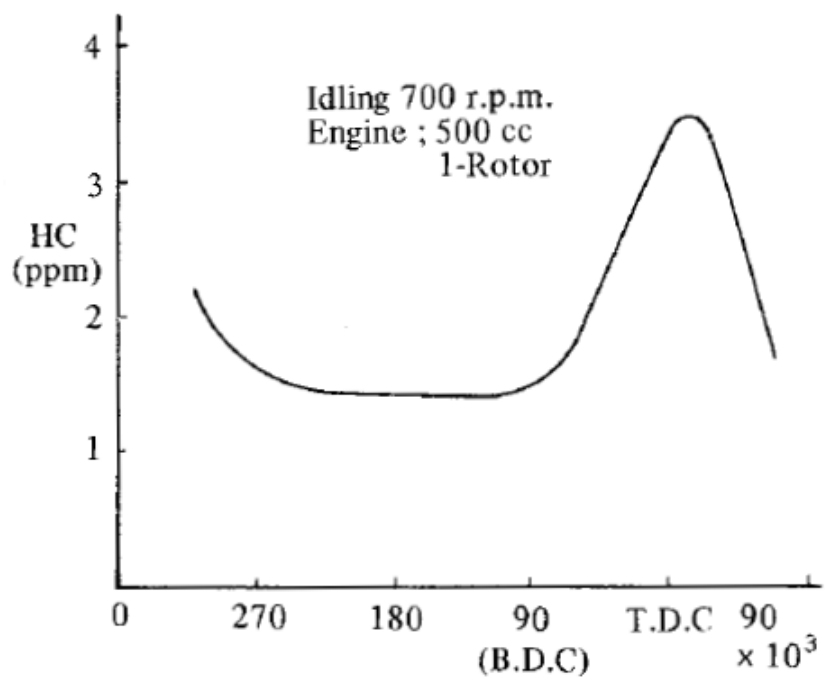

Shaft degree and $\mathrm{HC}$ concentration

Figura1-7 Concentração de HC na janela de exaustão em função do ângulo do eixo de manivela, (retirado de Rotary Engine (Yamamoto, 1971).

Os motores Wankel também podem sofrer um aumento de emissões de HC por vazamento de parte da mistura da câmara onde ocorreu a combustão para a câmara em processo de exaustão através do apex seal. Outra forma de aumento de emissões de HC é o excesso de blow-by para a região de admissão, que resulta em falhas da combustão.

Já as emissões reduzidas de NOx são justificadas pela baixa temperatura durante a combustão, devido à alta taxa de transferência de calor para as paredes da câmara. Outro fator para a redução de NOx é a concentração de gases queimados na mistura de admissão (Yamamoto, 1971). Uma vez que a composição dos gases queimados possui uma maior capacidade térmica, o que resulta em menores temperaturas pós queima, esses gases com maior capacidade térmica absorvem uma maior parte do calor gerado na queima, além de não participarem no processo de combustão.

\subsection{5.}

\section{Outros Motores Rotativos}

Além do motor Wankel, muitos outros já foram propostos, mas pouquíssimos foram desenvolvidos ou possuem dados experimentais publicados. Alguns tiveram um desenvolvimento inicial porém, por terem sido desenvolvidos pela indústria, 
nenhum material foi divulgado. Dessa forma é difícil discorrer comentários a respeito da operacionalidade desses motores, porém vale a pena citá-los aqui.

\subsubsection{1.}

\section{Motor rotativo de rotor articulado}

Dentro do conjunto de propostas dos motores rotativos, existe um que se baseia em uma máquina de deslocamento positivo chamado de máquina rotativa romboidal RRM ou máquina rotativa quadrilateral QRM (Al-Hawaj, 2015). Esse motor assemelha-se aos motores Wankel pela forma de epitrocoide do bloco do motor. Porém o componente de transmissão direta de potência, nesse caso um rotor articulado, difere de praticamente todos os motores rotativos. Os motores QRM, também chamados de motores quadrilaterais, possuem um rotor articulado formado por quatro segmentos que, ao rotacionar dentro do bloco, fazem o rotor variar seu formato constantemente, entre um quadrado e um romboide, dependendo da posição angular. A variação de volume dessa máquina rotativa de deslocamento positivo é obtida de modo similar aos motores Wankel, ou seja, a forma externa dos flancos do rotor difere da forma interna do bloco a cada posição angular do rotor (Figura 1-8).
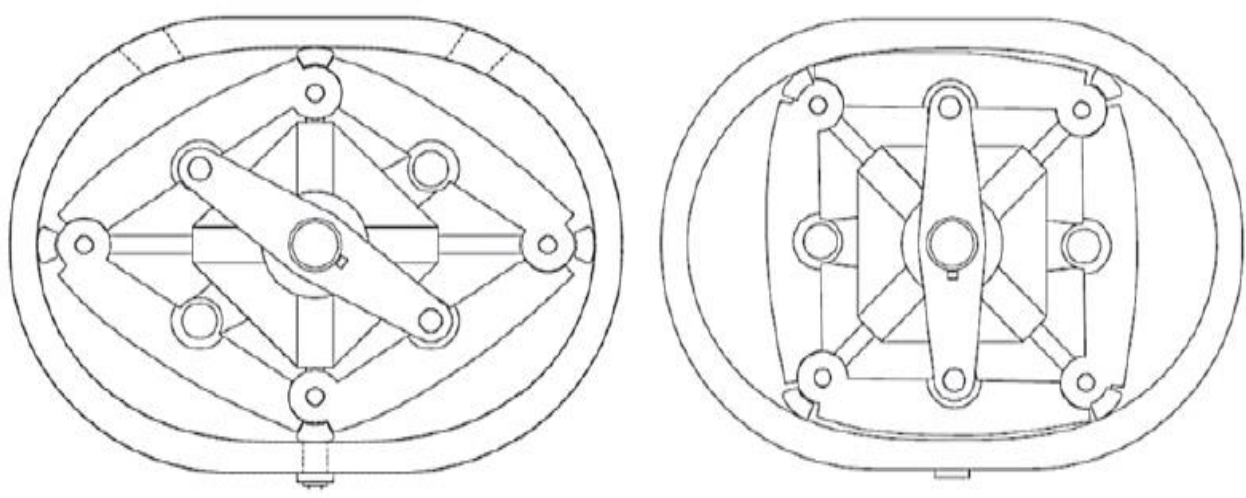

Figura 1-8 Esquema do motor rotativo quadrilateral (Al Hawaj, 2015))

A vantagem mecânica do motor quadrilateral sobre o motor Wankel é a transmissão direta de movimento rotativo do rotor para o eixo de saída. Ou seja, o movimento rotacional do rotor articulado é transmitido diretamente ao eixo de saída, sem a necessidade de eixos excêntricos, engrenagens, bielas ou quaisquer outros tipos de transmissão entre os componentes em contato com a combustão e o 
eixo de saída. No lugar das transmissões clássicas, o motor quadrilateral transmite o torque para o eixo de duas formas diferentes. Ou por um braço transversal ao eixo, fixo em apenas dois segmentos opostos do rotor, ou por eixos telescópicos, entre o eixo de saída e as terminações dos segmentos articulados. Desse modo a velocidade de rotação do rotor é a mesma do eixo de saída do motor.

O conceito de motor rotativo com rotor articulado data de 1902, do inventor Edward H Werner (Werner, 1902), com uma proposta de máquina de deslocamento positivo para gerar potência a partir de vapor. Outros avanços e patentes foram sendo publicadas com passar dos anos, de forma que o desenvolvimento mais recente, e com aplicação prática, é da empresa familiar Quasiturbine, cujo motor rotativo desenvolvido leva o mesmo nome. No site da empresa Quasiturbine (SaintHilaire), nos artigos e patentes publicadas (Saint-Hilaire, 2007), eles apresentam um motor rotativo acionado por pressão fornecida pela admissão, podendo ser ar comprimido ou vapor d'água. Esse motor acionado por pressão foi construído, Figura 1-9, e passou pela fase experimental, e atualmente possui diversos vídeos e imagens de suas aplicações práticas, disponíveis na internet.

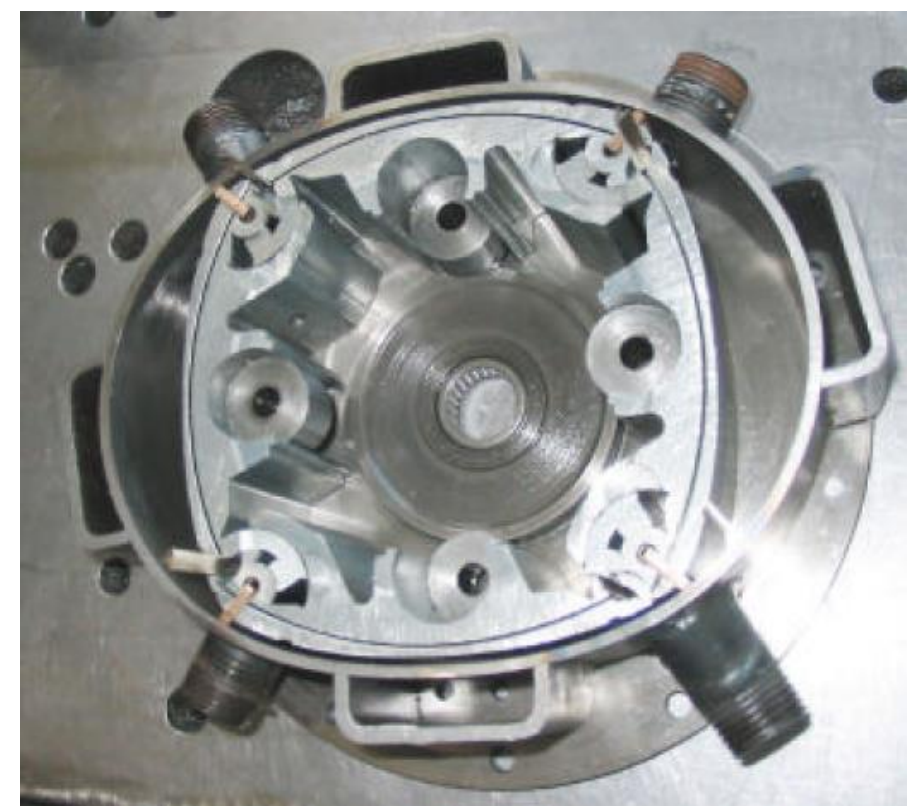

Figura 1-9 Interior do motor quadrilateral acionado por pressão de vapor (Saint-Hilarie, 2007)

Adicionalmente, a empresa propõe uma possível utilização da máquina rotativa em um motor a combustão interna, utilizando combustão por HCCI. No entanto, até o presente momento, não foi divulgada qualquer informação sobre o 
sucesso do funcionamento do motor rotativo proposto utilizando combustão por detonação. Além disso, não foi encontrado material sobre resultados obtidos em testes utilizando esse tipo de máquina como motor a combustão interna. No entanto, observando a trajetória e as características do motor Wankel, nota-se que o motor quadrilateral QRM possui características problemáticas similares às encontradas no motor Wankel. A primeira característica em comum e mais evidente entre os dois motores é a forma alongada da câmara de combustão, que no caso do Wankel, por ter uma razão superfície/volume superior aos motores alternativos, resulta em problemas de altos índices de emissão de $\mathrm{HC}$, e baixo rendimento térmico em motores de ignição por centelha. Além disso, motores rotativos a combustão interna sofrem com os constantes problemas de construção em torno das condições que garantam bom resfriamento, lubrificação e vedação para o pleno funcionamento do equipamento. Não foram encontradas informações mais detalhadas sobre esses pontos em motores quadrilaterais nas possíveis aplicações como motor a combustão interna.

Dos motores citados no presente trabalho, o do tipo QRM, ou RRM ou Quasiturbine não é abordado no livro de Felix Wankel (Wankel, 1965). No entanto, o autor aborda um motor similar, (Geiger, 1960) com mesmo princípio de funcionamento, cujos componentes de transmissão de potência efetuam trajetória similares.

Dessa forma é plausível classificar o esse motor como um PROM, Rotating Piston Machine, planetary rotation type, pois os componentes de transmissão de potência giram em velocidade constante, mas também possuem uma oscilação angular sobre si mesmo.

\subsubsection{2.}

\section{Orbital Sarich}

O motor orbital Sarich (Sarich, 1973), do inventor australiano Tony Ralph Sarich, foi desenvolvido pela Orbital Corporation, (Figura 1-10). Nesse motor as janelas de admissão e exaustão estão localizadas nas tampas laterais e opostas do conjunto do motor, sendo seu tempo de abertura e fechamento dependente do movimento orbital do rotor central. Nesse motor, como pode ser observado na (Figura 1-10), existem 6 câmaras onde ocorre a combustão, e a variação do volume 
é obtida pelo movimento orbital do rotor, com palhetas deslizantes que realizam um movimento alternativo de forma a garantir constante estanqueidade entre as câmaras. Devido a configuração de construção, tal motor foi feito sem ter capacidade de sucção da mistura de admissão, para funcionar como um motor de dois tempos. Sendo assim, um soprador ou compressor externo deverá ser utilizado para admissão da mistura na utilização do motor Sarich como motor a combustão interna propriamente dito. Para utilizá-lo como motor de quatro tempos, um sistema de abertura e fechamento de válvulas deverá ser utilizado, assim como nos motores alternativos de quatro tempos.

De acordo com a classificação de Wankel, o motor Sarich entraria no grupo das máquinas PROM, Rotating Piston Machine, planetary rotation type (Wankel, 1965). Um dos motivos que podem explicar o fracasso do motor orbital Sarich é a deficiência na capacidade de lubrificação do motor e do arrefecimento das partes essenciais ao seu funcionamento,

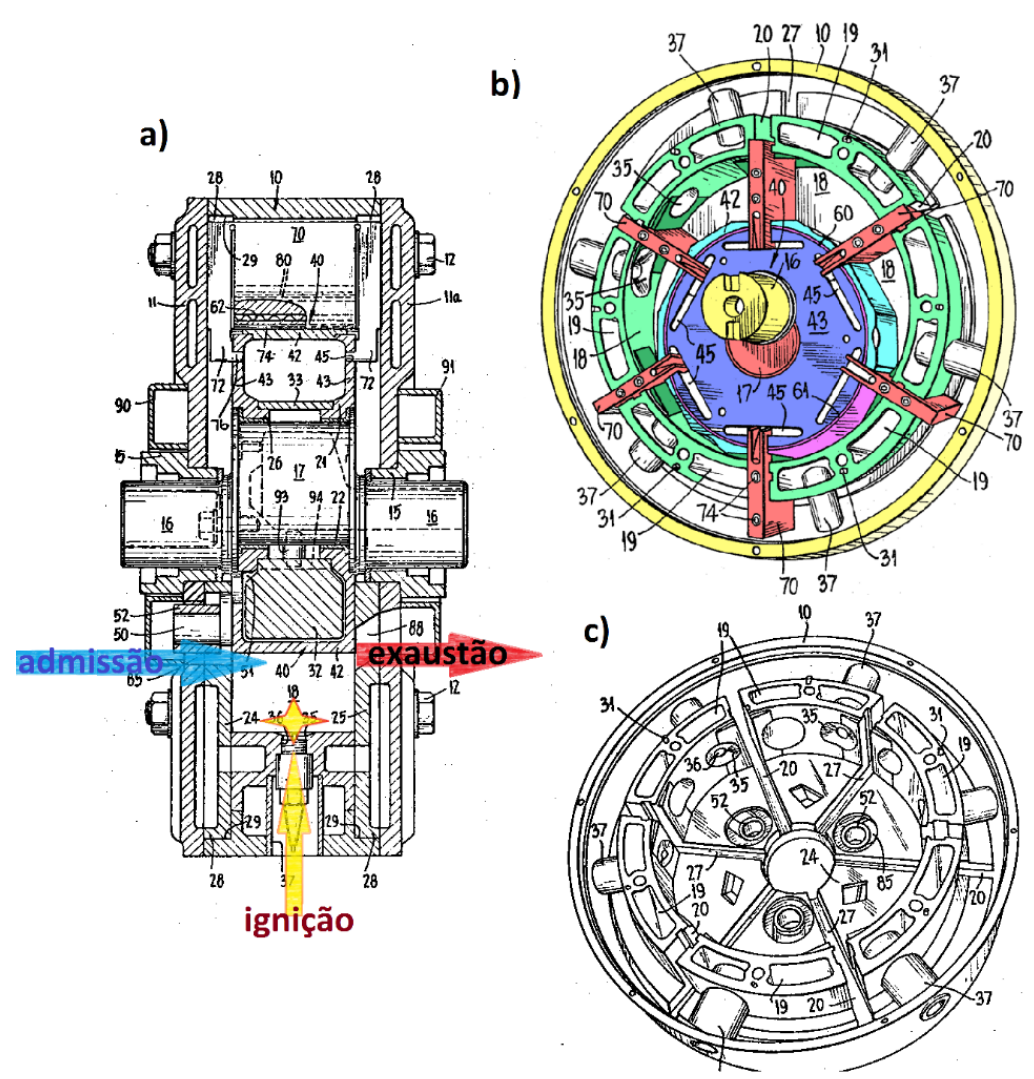

Figura 1-10 Ilustração da patente do motor Orbital Sarich. 


\subsubsection{3. Roundengine ou VGT}

Há também o motor VGT (Pekau, 2003; Karim \& Shrestha et al., 2000) que, até recentemente, possuía um site sobre seu desenvolvimento, com o título de RoundEngine. Entretanto, no momento não existem mais notícias sobre o desenvolvimento do motor. Como se pode observar na Figura 1-11, o motor em questão possui dois pistões (somente um deles identificado com o número 2 na Figura 1-11), acoplados a um rotor único, que gira em velocidade constante.

Perpendicular ao eixo do rotor há um disco com uma abertura (indicado pelo item 4 da Figura 1-11) rotacionando a velocidade constante, que controla os tempos de abertura para a passagem dos dois pistões. $\mathrm{O}$ ar é fornecido a pressão suficiente pela abertura 3 do motor, enquanto que o disco permanece na posição de fechamento da passagem do pistão. Conforme o conjunto pistão-rotor gira no sentido anti-horário o ar é comprimido entre o pistão 2 e o disco 4 e, então, a válvula 5 é aberta para permitir que o ar comprimido entre na câmara de combustão 6. Quando o pistão passa sobre a abertura 7, a válvula 5 é fechada e combustível é injetado na câmara 6, onde ocorre a combustão. Enquanto ocorre a combustão o disco gira de forma que o pistão possa passar da esquerda para a direita. Posteriormente, o disco fecha a passagem mais uma vez logo atrás do pistão. Dessa forma, uma válvula é aberta entre o disco e o pistão, à direita do disco, de forma que os gases da combustão voltem para a câmara toroidal, expandindo-se e empurrando o pistão conforme o conjunto pistão-rotor continuam a girar em sentido anti-horário. Os gases expandem até que o pistão passe pela abertura 8, por onde os gases saem para a exaustão. 

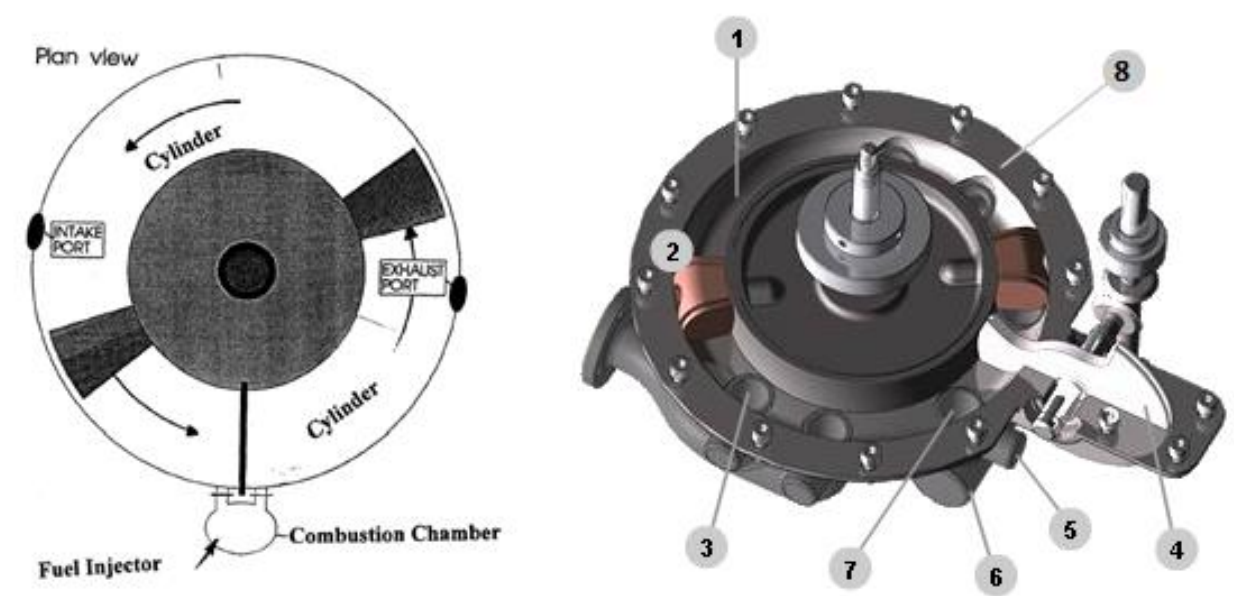

Figura 1-11 Ilustração do motor VGT ou Roundengine. À esq. imagem retirada de (Karim \& Shrestha et al., 2000), e à direita uma imagem retirada da webpage do motor Round Engine, atualmente indisponível.

\subsubsection{4.

Outro motor com pouca informação na literatura é o Rotatorque, cuja única referência é de um site em alemão (Schönrock) que mostra um motor rotativo de palhetas deslizantes, similar à máquina rotativa de Ramelli de 1588 (Wankel, 1965), em nome de Markus Schönrock. A Figura 1-12 ilustra o interior do motor Rotatorque. Assim como a máquina de Ramelli, o motor Rotatorque é classificado como PROM, Rotating Piston Machine, planetary rotation type, de acordo com a classificação de máquinas rotativas de Felix Wankel (Wankel, 1965).

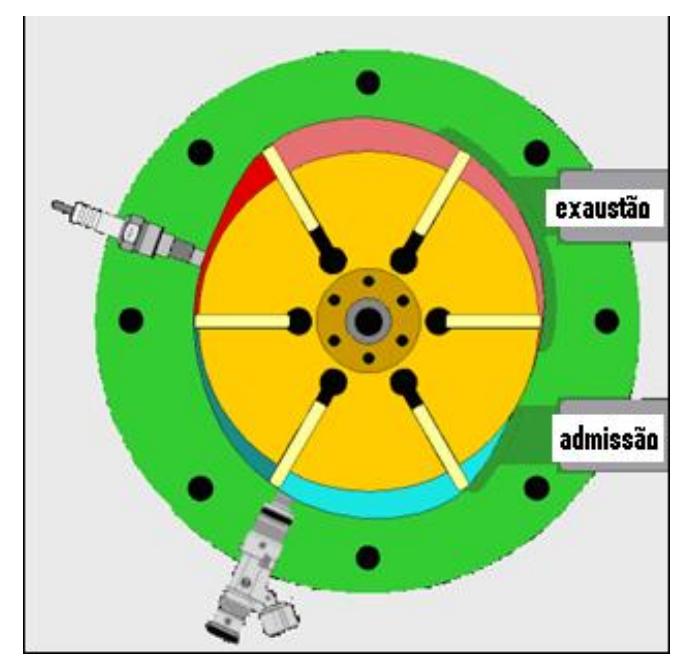

Figura 1-12 Motor Rotatorque (Schönrock) 


\subsubsection{5.}

\section{Cooley, Umpleby e Liquidpiston}

Dentre os motores rotativos, um dos que atualmente se encontra em fase de desenvolvimento é o LiquidPiston (LiquidPiston, 2016), de funcionamento semelhante ao do motor a vapor de Cooley (1903). Esse tipo de motor já foi trabalhado por Umpleby ( 1908), também pela Renault e ISUZU, em 1963 (Wankel, 1965). A ideia original abordada por Cooley era de um motor a vapor rotativo, onde tanto o rotor quanto o bloco do motor giram com velocidades diferentes, constantes e no mesmo sentido. Posteriormente tal máquina de deslocamento positivo foi adaptada para um motor a combustão interna, com o bloco do motor estacionário e o rotor efetuando um movimento contínuo sobre o próprio centro de gravidade, que gira em excentricidade ao redor do centro do bloco do motor, em um movimento similar ao do motor Wankel. Nesses motores rotativos a combustão interna, as misturas de admissão e exaustão entram e saem das câmaras pelas janelas localizadas no perímetro do rotor, e não pelas paredes estacionárias. A abertura e fechamento das janelas de admissão e exaustão depende da posição do rotor. $\mathrm{Na}$ Figura 1-13 estão ilustradas os motores Cooley, o Umpleby e o Liquidpiston.

De acordo com a classificação de Wankel, o motor Cooley estaria dentro da categoria dos SIM Single Rotation Machine, enquanto que o Umpleby e LiquidPiston seriam classificados como PLM Planetary Rotation Machine (Wankel, 1965). 


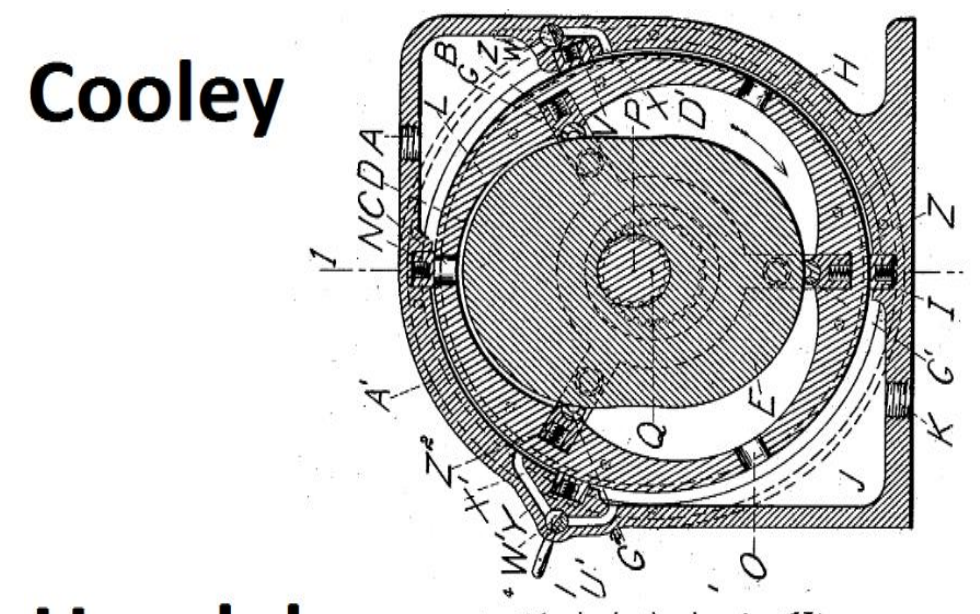

\section{Umpleby}
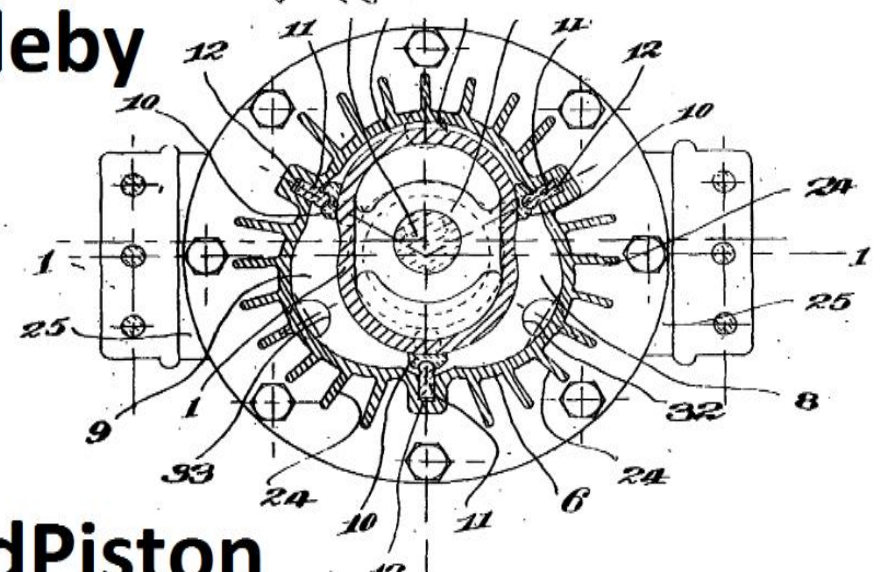

\section{LiquidPiston}
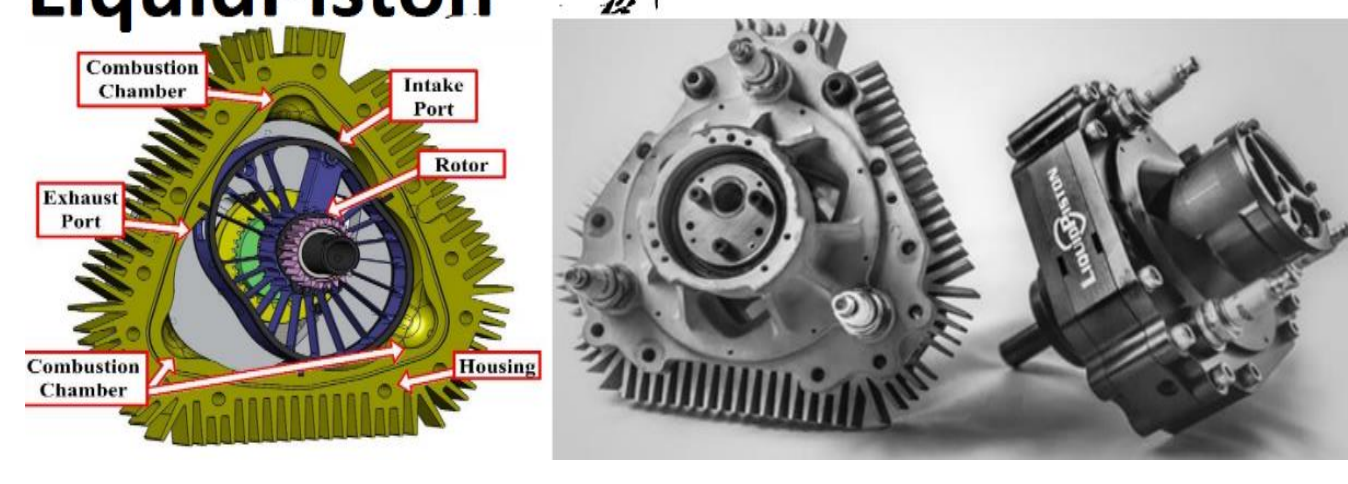

Figura 1-13 Ilustrações dos motores Cooley (Cooley, 1903) Umpleby (Umpleby, 1908) e LiquidPiston (LiquidPiston, 2016)

\subsection{6.}

Motor de pistões rotativos de eixos concêntricos

Entende-se por central-axis rotating piston engine, single rotation type SROM, de acordo com a classificação de Felix Wankel (Wankel, 1965), qualquer configuração de motor cuja variação do volume da câmara de combustão é obtida através do movimento rotativo relativo entre deslocadores, acoplados a dois rotores girando lado a lado sobre o mesmo eixo de rotação Figura 1-14. A esse tipo de 
motor foi atribuído diversos nomes informais, como Cat-and-mouse, Scissor Type (Norbye, 1967), Oscilatoy Rotating Piston Engine ORE (Yamamoto, 1971), StopAnd-Go (Wankel, 1965), Pursuing Piston Engine ou simplesmente Twin-Rotor Piston Engine TRPE (Deng et al., 2012). Não existe nenhum rigor a respeito de qual nome utilizar, sua escolha depende mais da preferência do autor do que um critério técnico em si, tendo como objetivo principal fornecer uma analogia didática para o entendimento do funcionamento da máquina. Deste ponto em diante do presente trabalho a sigla TRPE será utilizada para se designar esse tipo de motor.

\subsubsection{1.}

\section{Princípio de funcionamento dos motores TRPE}

Os motores da categoria TRPE diferem entre si em relação à geometria da câmara de combustão, podendo ser anular ou toroidal, e também pelo sistema de acionamento mecânico, responsável por converter o movimento oscilatório dos pistões e rotores em um movimento contínuo do eixo de saída. Como o sistema de acionamento é particular de cada motor, ele será comentado para cada tipo de motor aqui apresentado. Mas a característica que é comum a todos os motores dessa categoria, à qual se referem os inúmeros apelidos criados, é justamente a dinâmica dos pistões. Nesses motores, todos os deslocadores estão sempre envolvidos em dois processos termodinâmicos distintos e simultâneos, um a frente e outro atrás do deslocador em relação ao sentido da rotação. Assim, cada deslocador possui uma câmara de trabalho à frente e outra atrás, onde ocorrem os processos termodinâmicos. Além disso, um deslocador fixado ao primeiro rotor sempre possui dois outros deslocadores adjacentes, um a frente e outro atrás, sendo esses dois acoplados ao segundo rotor. Dessa forma, quando um deslocador se aproxima do deslocador à frente, ele se afasta do pistão anterior, ou seja, quando se reduz o volume da câmara posterior, aumenta-se o volume da câmara anterior e vice-versa, sendo que isso vale para todas as câmaras do motor. Mas é importante lembrar que esse movimento de "aproxima e afasta" relativo entre pistões ocorre durante o movimento rotativo unidirecional de ambos os rotores, com sucessivas acelerações e desacelerações.

Para visualizar mentalmente o funcionamento do motor é interessante que se divida o movimento dos pistões em duas partes que devem ser entendidas em duas 
etapas para facilitar a compreensão do funcionamento. Primeiramente avalia-se apenas o movimento relativo entre pistões que se assemelha ao movimento de corte de uma tesoura, com suas duas lâminas e dois cabos abrindo e fechando repetitivamente. Substituindo-se mentalmente as duas lâminas e cabos por pistões, obtém-se um movimento de aproximação e afastamento entre pistões, que se repete durante o ciclo do motor.

Entendido o movimento relativo entre pistões, aplica-se uma velocidade uniforme ao conjunto, de forma que o pistão nunca mude o sentido da velocidade angular real. Dessa forma os pistões sempre se movimentam em apenas um sentido, acelerando e desacelerando fora de fase conforme giram sobre o eixo central dos rotores.

O que impõe o movimento relativo do conjunto, e a variação de volume das câmaras entre os pistões, advém da diferença entre as velocidades angulares dos dois rotores, sobre os quais os pistões são fixos.

Assim como em motores alternativos de quatro tempos, o motor rotativo TRPE segue o mesmo princípio de funcionamento com quatro tempos: admissão, compressão, expansão e exaustão. A diferença é que nesses motores, devido a sua natureza rotativa, o volume de ar admitido é "carregado" pelos pistões, de forma que os processos do ciclo termodinâmico ocorram em regiões específicas do bloco do motor, ao contrário de motores alternativos, onde todos os processos ocorrem na mesma região. A Figura1-15 mostra de forma esquemática o passo a passo do funcionamento de um motor TRPE rotativo. Como se pode notar, os pistões se aproximam em duas regiões do motor, uma na parte superior e outra na parte inferior. Na parte superior a aproximação ocorre quando a câmara entre os dois pistões se encontra no final da fase de exaustão e início da admissão, e na parte inferior, quando a câmara entre os pistões se encontra na fase final da compressão e início da expansão, já com a combustão em curso. 


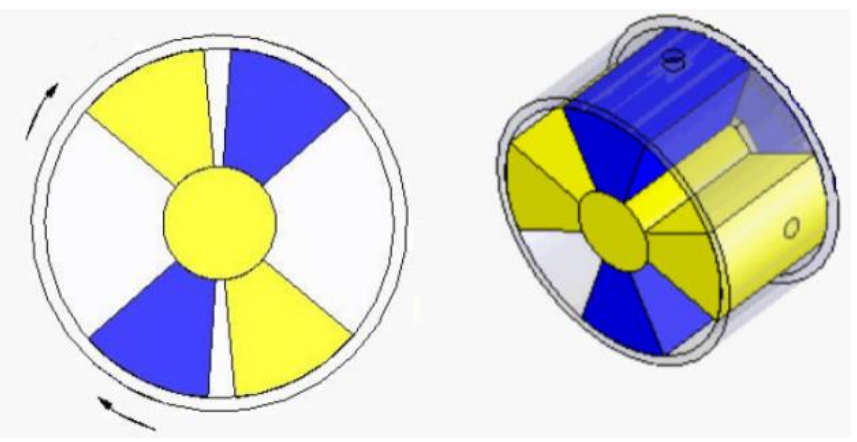

Figura 1-14 Exemplo de twin-rotor piston engine TRPE na configuração com câmara de formato anular, (Kopelowicz, 2009).

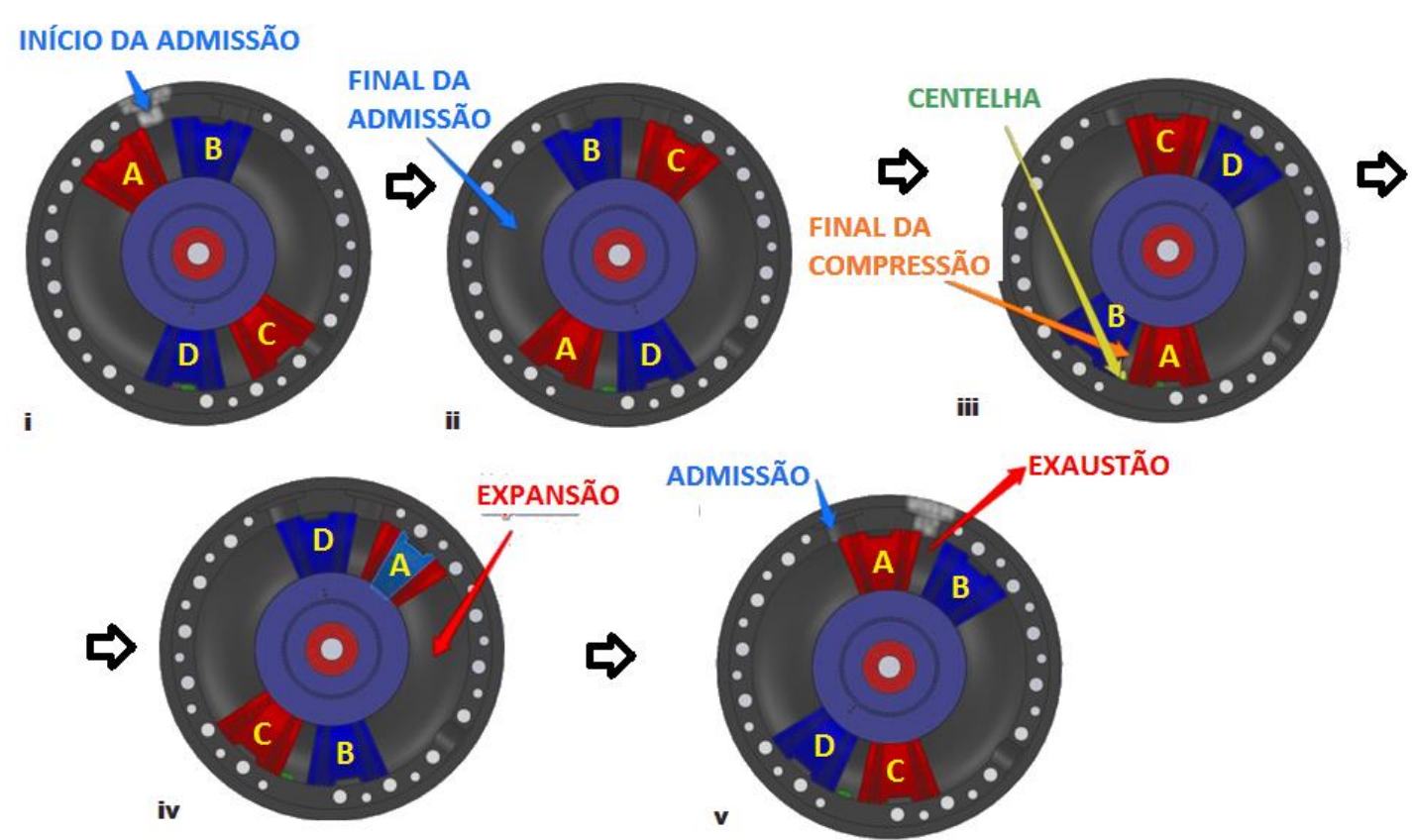

Figura1-15 Funcionamento de um motor Twin-Rotor Piston Engine ou TRPE: (i) início da admissão, (ii) fim da admissão, (iii) combustão, (iv) expansão e (v) fim da exaustão. (imagens do projeto do motor Kopelrot)

Nesses motores, conjuntos de pistões são acoplados a ambos os rotores. Quando o número de pistões em cada rotor for igual a $\mathrm{N}$, existem $2 \mathrm{~N}$ câmaras de trabalho, e N/2 sistemas de ignição, portas de admissão e exaustão (Deng et al., 2012). Ou seja, em motores com quatro pistões no total, são dois pistões para cada rotor, quatro câmaras de trabalho, e apenas um sistema de ignição, uma porta de admissão e uma porta de exaustão. 


\subsubsection{2. \\ História e desenvolvimento}

A proposta de motor utilizando o princípio de movimento oscilatório relativo entre pistões acoplados a um par de rotores surgiu há um pouco mais de um século atrás, primeiramente como conceito para motores a vapor, e posteriormente em motores à combustão interna. De antemão, é importante lembrar-se das definições de motores rotativos (Wankel, 1965), para não confundir motores rotativos com motores com pistões que se movimentam em um espaço toroidal ou anular. Ou seja, não é porque o motor possui uma câmara de formato toroidal, ou anular, que esse motor será necessariamente rotativo. A câmara pode ser de formato toroidal, com seus pistões realizando um movimento alternativo de ida e volta de trajetória em arco, mas ainda sim são alternativos. Ou seja, independente do formato das paletas, pistões ou deslocadores, o movimento dos componentes é o que importa para saber se é um motor rotativo ou alternativo. Dessa forma, os seguintes motores, citados em literaturas mais recentes, o Roundengine ou Variable Geometry Toroidal Engine VGT (Karim \& Shrestha, 2000; Pekau, 2003) e Rotoblock (Farrell, 1993), não serão considerados na categoria de motores rotativos Twin Rotor. Uma vez que o Roundengine é um motor cujos eixos de rotação de suas partes móveis estão dispostos perpendicularmente entre si, o que faz com que ele se enquadre em uma outra categoria de motores rotativos, enquanto que o Rotoblock é um motor alternativo, com movimento de vai e volta dos rotores, acoplados ao eixo de saída através de biela e manivela.

Entendendo o princípio de funcionamento desses motores, é importante saber que os motores rotativos utilizando dois rotores surgiram originalmente como motores a vapor, e a patente mais antiga de que se tem informação data de 1884, do inventor Oehlmann (Oehlmann, 1884), Figura1-16(a). Posteriormente o conceito de motor a combustão interna alternativo com câmara toroidal foi proposto em 1910 por Frederic Beck (Beck, 1910), (Figura1-16 (c)), e em 1911 por Dewandre Albert (Dewandre, 1910) (Figura1-16(b)). Em novembro de 1909, a revista britânica Flight publica um artigo sobre o motor de Beck, exposto na primeira edição da exposição do Paris Air Show (Flight, 1909) (Figura1-16(f)).

Alguns anos depois, é proposto o primeiro motor a combustão interna rotativo, utilizando o conceito de dois rotores, por Antonio Sanchez e Claudio 
Baradat (Sanchez \& Baradat 1914) (Figura1-16(d)) com a configuração de câmara toroidal. No entanto, outros autores (Deng et al., 2012) afirmam que esse tipo de motor foi proposto por Bullington, em 1924 (Figura1-16(e)), na configuração com a câmara em forma anular.

Independentemente do formato da seção do pistão rotativo, o princípio de funcionamento de ambos os TRPE é o mesmo, se analisado o trajeto do centro de gravidade de seus componentes de transmissão de potência. Assim, é totalmente razoável considerar o motor de Sanchez e Baradat como a patente mais antiga desse tipo de motor a combustão interna.

Esse conceito de motor continuou a ser aprimorado nas décadas seguintes, seguindo a onda do desenvolvimento dos motores rotativos, na mesma época do sucesso do surgimento do motor Wankel. $\mathrm{O}$ assunto ganhou artigo e capa na revista Popular Science no exemplar de janeiro de 1967 (Norbye, 1967), que traz informações sobre os "novos rivais do motor Wankel”. Em seu artigo, ele apresenta três motores rotativos TRPE, o Kauertz (1964), Tschudi (1968) e o Virmel (Melvin, 1967). Os motores Kauertz e Virmel apresentam-se como motores de câmara anular, enquanto que o Tschidi utiliza câmara toroidal. No artigo, é relatado que experimentos com o motor Kauertz obtiveram uma potência de 158 kW, a 2000 RPM com volume deslocado de 1 litro, "funcionando de forma suave como um motor V8" (Norbye, 1967).

Além disso, os três motores diferem entre si em seu sistema de transmissão de conversão mecânica do movimento oscilatório dos pistões para rotação constante do eixo de saída (Figura1-17). O motor Kauertz utiliza um sistema mecânico de solar-planetária simples e biela manivela, de forma que um par de pistões sempre orbite em velocidade constante, enquanto que o outro par gira em velocidade variável, resultando num movimento relativo entre pistões consecutivos. No motor Tschudi, o movimento oscilatório é obtido mediante um sistema mecânico de rolos e um eixo de came com um ressalto e um recesso, de forma que o torque é transmitido por meio de um dos rolos acoplando-se a um dos recessos do eixo de came. Já o motor Virmel utiliza um sistema parecido com o Kauertz, utilizando um sistema de solar com duas planetárias e biela manivela. O esquema mostrando o funcionamento de cada um dos três motores pode ser visto na Figura1-17. 


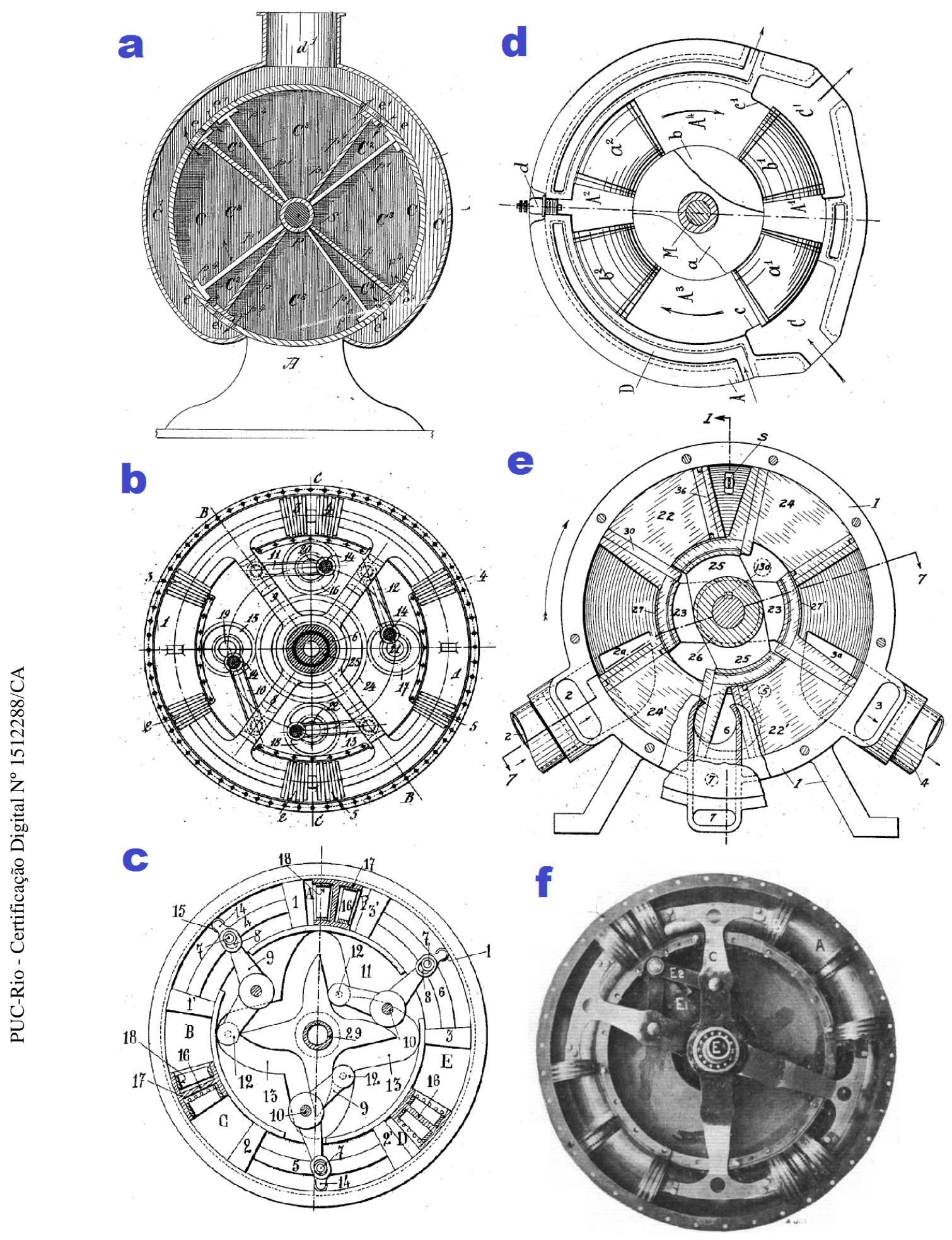

Figura1-16 Esquema das câmaras de trabalho de cada um dos seguintes motores: (a) E. Oehlmann, (b) Dewandre,(c) Beck,(d) Sanchez \& Baradat,(e) Bullington, retirado das respectivas patentes (Oehlmann., 1884) (Dewandre, 1910) (Beck, 1910) (Sanchez \& Baradat, 1914) (Bullington, 1924), e (f) a imagem do motor Beck divulgada na revista Flight (Flight, 1909). 

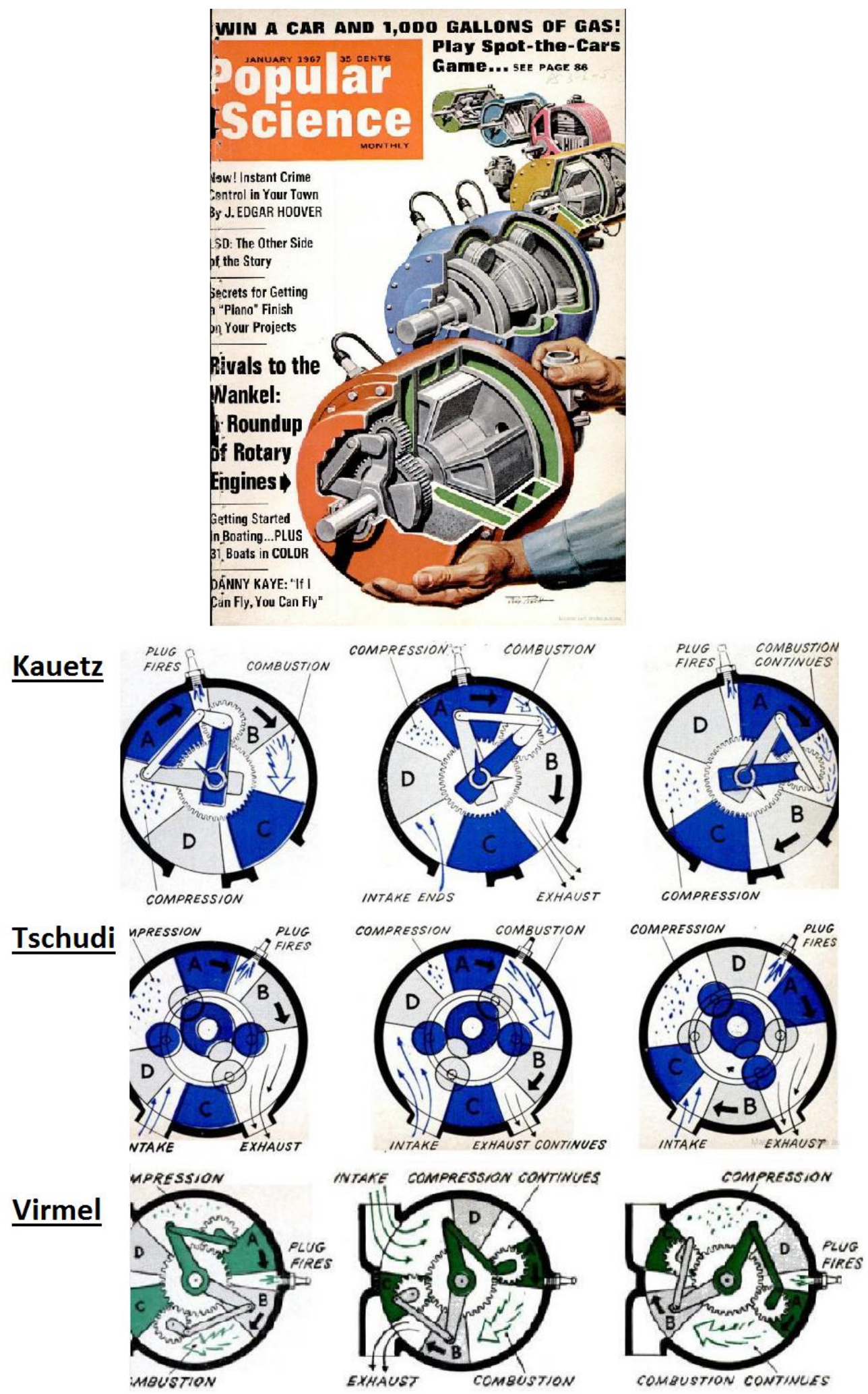

Figura1-17 Na parte superior a capa da Popular Science, e abaixo, de cima pra baixo, os esquemas dos motores Kauertz, Tschudi e Virmel, respectivamente retirados do artigo da revista Popular Science, (Norbye, 1967). 
Nas décadas seguintes outros inventores continuaram a propor mais motores TRPE, como o motor Taurozzi em 1974 (Taurozzi, 1974), Kopelrot em 1988 (Kopelowicz ,1988; Kopelowicz et al., 2009; Kopelowicz, 2012; Ticona et al., 2015; Jiménez, 2008; Guarato et al., 2015; Guarato et al., 2016), David B. Wittry (Wittry, 1995), Sakita (2002), Morgado (2004) (Figura 1-18). Em 2010 um conjunto de empresas russas formaram a empresa "Yo-Auto", que desenvolveria o automóvel híbrido "Yo-mobile" (ё-мобиль) utilizando motor rotativo a combustão interna do tipo TRPE (Kramer, 2010). No entanto, pouco tempo depois a ideia de utilizar o motor rotativo foi suspensa, uma vez que foi reclamada a autoria do motor por outra pessoa. Em 2014 a empresa é vendida para o governo russo, sem nunca ter chegado a comercializar um veículo sequer. Não existem dados experimentais disponíveis sobre esse motor rotativo russo, mas é de se reconhecer o quão próximo de ser fabricado em larga escala esse motor rotativo esteve.
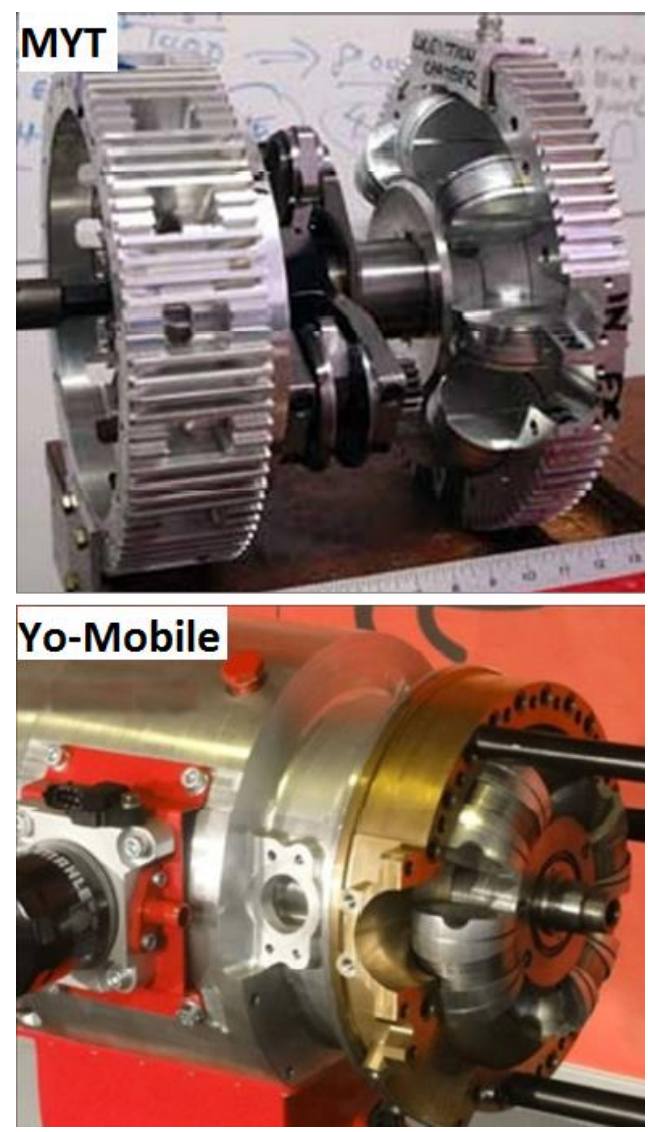

Figura 1-18 (sup.) motor MYT de Morgado. (inf.) motor do Yo-mobile (ё-мобиль) (Zou et al., 2014).

Até o presente momento, como já foi dito anteriormente, o único motor a conseguir um sucesso comercial foi o motor Wankel. No entanto, os motores TRPE receberam e ainda recebem muita atenção, e são objeto de estudo e experimentos 
desde a década de sessenta. Pode-se arriscar a afirmar que, além do motor Wankel, os motores TRPE foram os motores rotativos que mais se aproximaram de um possível sucesso, o que significaria um concorrente potencial ao motor Wankel. Curiosamente, os motores do tipo TRPE receberam críticas especiais no livro Rotary Engine (Yamamoto, 1971), da Mazda, e no Rotary Piston Machines (Wankel, 1965), do próprio Felix Wankel.

No entanto, de todos os motores rotativos TRPE propostos, os únicos a apresentarem uma razão de compressão variável são os motores Kopelrot e Wittry. Porém, a solução proposta por Wittry na verdade é um mecanismo que permite a execução de um ciclo Atkinson em um motor rotativo, através de uma válvula de ajuste variável na lateral do motor (Wittry, 1995), o que possibilita que parte dos gases saia da câmara durante a fase de compressão, e escoe para a fase de admissão na câmara de trabalho anterior. Dessa forma o único motor a realmente apresentar um mecanismo de variação da razão de compressão do motor, independente da variação do volume admitido e, consequentemente, de um ajuste de volume nocivo e deslocado, é o motor Kopelrot.

\subsection{7.}

\section{Evolução do Motor Kopelrot}

O objeto de estudo do presente trabalho, o motor Kopelrot, conta com um já significativo histórico de material publicado, que cabe aqui citá-los.

Monteiro (2001) e Monteiro et al., (2001) apresenta os primeiros estudos e uma simulação, com mecanismo similar ao presente motor, em um compressor rotativo, conforme citado por Jimenez (2008).

Barreto et al. (2003) e Barreto et al. (2004) dá o prosseguimento do trabalho anterior, incluindo na simulação a análise cinemática e dinâmica do compressor. No compressor proposto, ainda é utilizado um sistema de acionamento composto por manivelas acopladas entre o conjunto pistão-rotor e os pinos que deslizam em uma ranhura localizada no disco volante do eixo de saída.

Em 2005 (Kopelowicz et al., 2005) é apresentada a avaliação de resultados experimentais de um protótipo de um compressor construído com base ao mecanismo dos deslocadores (com o acionamento do eixo de potência via um haste central e pinos deslizantes). 
Em Jimenez (2008) apresenta em sua dissertação uma simulação para o mecanismo proposto funcionando como motor a combustão interna. Seu trabalho apresenta resultados de simulação para o motor funcionando com três combustíveis diferentes. Nesse trabalho, um novo sistema de acionamento é utilizado, dois conjuntos de manivelas ligadas a hastes que por sua vez estão ligadas ao volante do eixo de saída. Esse sistema mecânico é formado por dois "quadriláteros" articulados.

Em 2009, Kopelowicz et al. (2009) apresenta o mesmo motor abordado no trabalho de Jimenez, com informações a respeito da fabricação de um primeiro protótipo.

Em 2015, Ticona et al. (2015) apresenta um modelo termodinâmico do motor, avaliando as vantagens de se aplicar o ciclo Miller no motor Kopelrot, com pistões de seção circular. Posteriormente, ainda em 2015 Guarato et al. (2015) apresentam as vantagens do motor proposto justamente com a penúltima configuração do motor, com o sistema de aplicação do ciclo Miller e o sistema de acionamento mecânico com engrenagens solares-planetárias, mas ainda com os pistões de seção circular e câmara de formato toroidal.

Em 2016, Guarato et al. (2016) apresentam a última versão do motor, com pistões de seção quadrada e espaço da câmara anular. $O$ trabalho apresenta um detalhamento de todos os componentes do motor, além dos resultados da simulação do sistema de variação da razão de compressão de acordo com a excentricidade. Também são mostradas as fotos de dois protótipos, o primeiro feito em poliamida e madeira, e o segundo em metal, sendo esse segundo o protótipo o que será utilizado para avaliação experimental no presente trabalho. Das inovações do protótipo em metal destacam-se os pistões, em aço inox fabricados em impressora 3D, com canais de circulação de óleo para o sistema de arrefecimento dos pistões.

No primeiro trimestre de 2017 é finalizada a etapa de fabricação do modelo funcional e inicia-se a fase de ajustes, montagem e revisão de projeto. Essas etapas estão descritas nos próximos capítulos do presente trabalho, além da montagem da bancada de projeto e testes preliminares de acionamento. 


\section{4. Informações adicionais sobre motores rotativos}

Ao contrário do que se possa imaginar, o problema com gradientes de temperatura localizadas e dilatações térmicas heterogêneas em certos motores rotativos não se deve ao fato da combustão ocorrer 'no mesmo local', e sim porque os outros processos termodinâmicos do ciclo de quatro tempos ocorrerem em local diferente de onde ocorre a combustão. Mas isso não é regra para todos motores rotativos, e essa é uma colocação relativa. Um exemplo disso é o motor Umpleby ou Liquidpiston, onde todos os processos termodinâmicos ocorrem no mesmo local onde ocorre a combustão, se for tomada como referência a parte estática do motor. No entanto, como o tempo de abertura e fechamento das janelas é controlada pelo rotor, para cada instante de cada processo termodinâmico em cada uma das três câmaras uma mesma fração da superfície periférica do rotor estará exposta ao mesmo processo termodinâmico, quando esse processo ocorrer em cada uma das câmaras. Ou seja, enquanto gira, uma mesma porção do rotor sempre estará exposta aos processos de combustão, enquanto que o lado oposto do rotor não estará. Nesse motor, o "local problemático", que sempre está em contato com os processos de combustão, está localizado no rotor, e não no bloco do motor.

\section{5.}

\section{Conclusões a respeito da revisão bibliográfica}

É importante ressaltar aqui a existência da grande quantidade de configurações possíveis para motores rotativos. Ideias e patentes existem em grande quantidade, e mesmo dentro de uma mesma configuração de motor rotativo, existem diversas variações que podem resultar outras configurações. O número de projetos e patentes não para de crescer, mesmo nos dias atuais, sendo que muitos dos mecanismos propostos são readaptações de máquinas de deslocamento positivo já propostos como motores a vapor do século XIX e início do século XX. No entanto, são poucos os motores que atingiram algum grau de desenvolvimento e, consequentemente, chegaram à construção de um protótipo. Dentre os motores que se desenvolveram ao nível de protótipo, a grande maioria só possui registro de funcionamento sendo acoplado a uma fonte externa de potência, seja acionado por injeção de pressão, pressure driven, ou movimentado por algum tipo de força motriz 
externa. Outros desenvolveram-se até a etapa de protótipos para possíveis compressores, mas raríssimos são aqueles que são testados com combustão propriamente dito, e dentre aqueles que foram testados com combustível, praticamente todos apresentam poucos dados sobre a performance do motor, limitando-se a informar a potência, volume deslocado e rotações por minuto. $\mathrm{O}$ único que se tem conhecimento é o motor Wankel, que como já foi dito, fracassou ao não cumprir as normas da euro V (Aautocar, 2010). É claro que existem poucos motores rotativos sendo desenvolvido atualmente, mas é de se estranhar que os poucos existentes são apresentados como possíveis substitutos para aplicações onde não existem regulamentações ambientais rigorosas, baseadas em teste de emissões, seja em drones, pequenos veículos e pequenos equipamentos, como roçadeiras e motosserras devido ao fato de motores rotativos possuírem uma boa relação peso/potência, o que os faz convenientes e convidativos na sua aplicação em pequenos equipamentos.

\section{6.}

\section{Estrutura do Trabalho}

A presente dissertação foi dividida em 5 capítulos. O capítulo 2 apresenta a descrição do Motor Kopelrot e a explicação de seus subsistemas. O capítulo 3 descreve toda a etapa de revisão de projeto e montagem do motor. O capítulo 4 aborda a avaliação experimental e o aparato experimental utilizado. No capítulo 5 são feitos comentários finais acerca do que foi feito, além de propostas para aprimoramentos do motor Kopelrot. 


\section{2 \\ Descrição do Motor Kopelrot}

O motor Kopelrot é um motor rotativo, do tipo cat-and-mouse, ou também chamado de Twin Rotor Piston Engine (TRPE), que se difere dos demais motores rotativos da mesma categoria por possuir um sistema de mudança de taxa de compressão, e um sistema de mudança da posição do Ponto Morto Superior

\section{1.}

\section{Divisão em módulos do motor Kopelrot}

O motor Kopelrot pode ser dividido em duas grandes partes, o sistema de conversão de energia (ECS - Energy Conversion System), e o mecanismo de acionamento de velocidade diferencial (DVDM - Diferential Velocity Drive Mechanism), Figura 2-1, Figura 2-2 eFigura 2-3. O Sistema de Conversão de Energia é onde ocorre a combustão, e o Mecanismo de Acionamento de Velocidade Diferencial onde se converte o movimento oscilatório dos rotores em um movimento contínuo e uniforme para o eixo primário de saída.

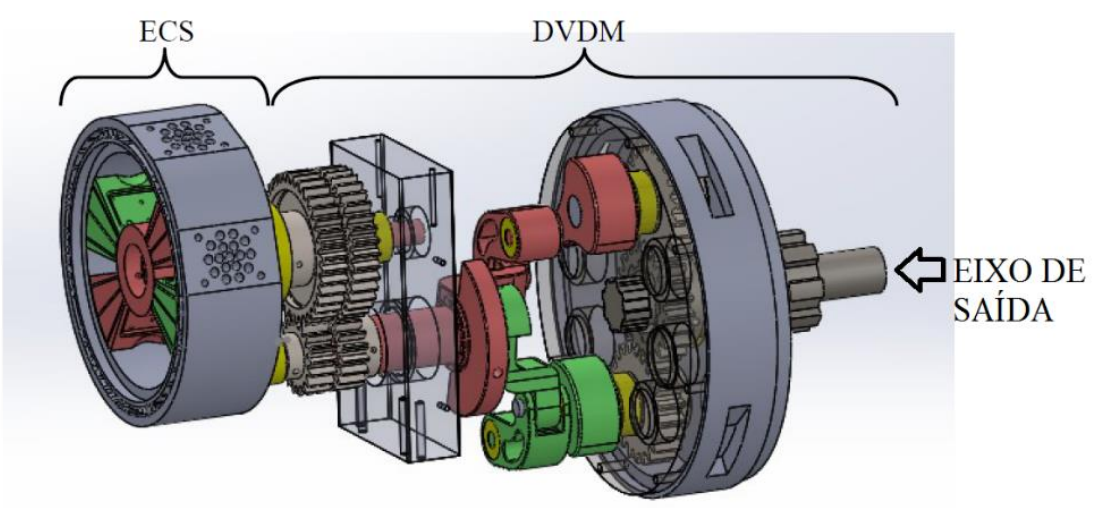

Figura 2-1 Visualização dos módulos do motor Kopelrot. Modelo em software SolidWorks

Na Figura 2-4 pode ser observado mais claramente como funciona o sistema de transmissão desse motor, composto por duas engrenagens planetárias, uma solar, duas bielas, dois eixos concêntricos e um eixo de saída. A Figura 2-3 mostra o sistema de conversão de energia, que possui dois rotores, quatro pistões, ou 
deslocadores, e a câmara cilíndrica do motor, composta por um cilindro vazado, e um conjunto de tampas laterais, tendo a função de facilitar a montagem, a execução do acabamento superficial da superfície interna da câmara de trabalho, e também formar canais de passagem do fluido do sistema de arrefecimento do motor.

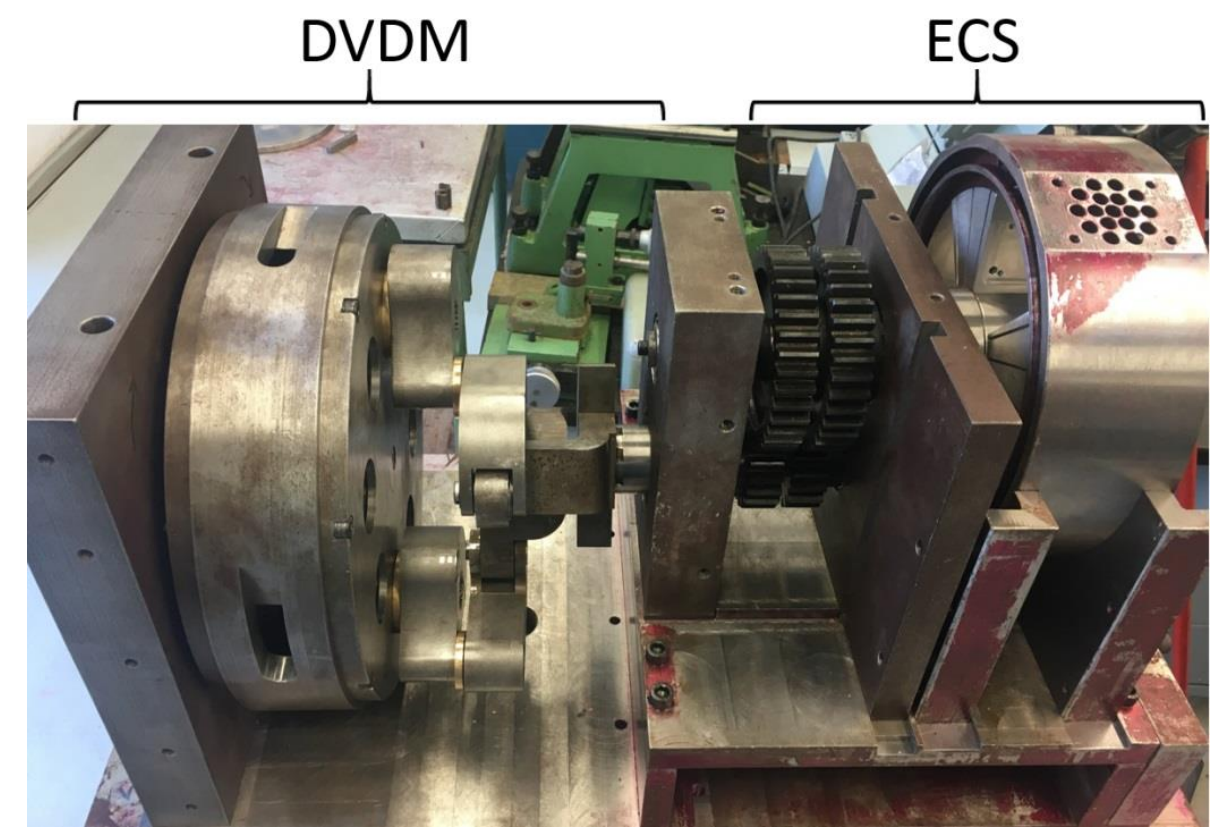

Figura 2-2 Divisão de módulos do modelo real com a câmara sem as tampas laterais

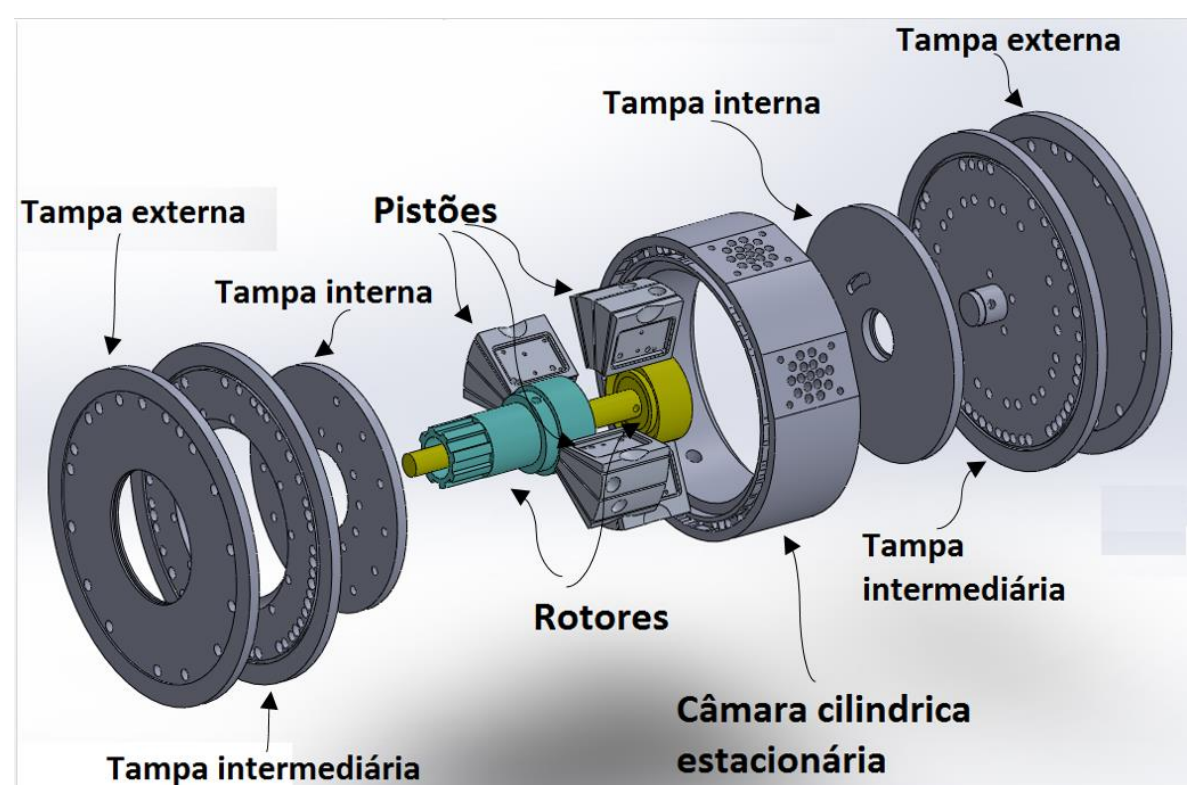

Figura 2-3 Sistema de Conversão de Energia (ECS). Modelo em software SolidWorks 


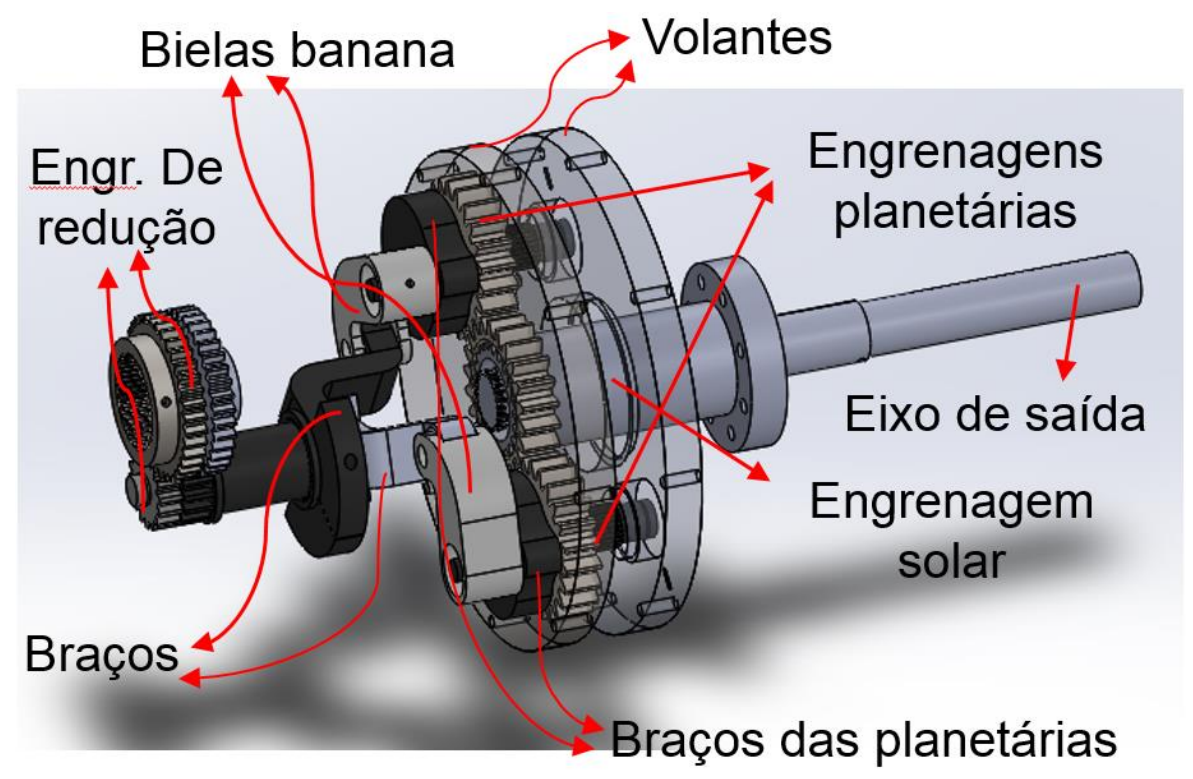

Figura 2-4 Mecanismo de acionamento de velocidade diferencial (DVDM). Modelo em software SolidWorks

\section{2. \\ Mecanismo de Acionamento de Velocidade Diferencial DVDM}

Para entender o funcionamento do motor Kopelrot é necessário que se entenda o funcionamento de cada uma de suas partes e as peças constituintes. A seguir serão mostrados componentes e sistemas.

\subsection{1.}

\section{Componentes do DVDM}

O Mecanismo de Acionamento de Velocidade Diferencial é formado pelas seguintes peças:

- 1x Eixo de saída

- 2x Volantes

- 1x Cilindro da planetária

- 1x Eixo da solar

- 1x Cabeçote da solar

- 1x Engrenagem solar

- 2x Engrenagens planetárias

- 2x Eixos da planetária

- 2x Braços da planetária 
- 2x Bielas banana

- 1x Braço de transição interno

- 1x Braço de transição externo

- 1x Eixo interno inferior

- 1x Eixo externo inferior

- 1x Pinhão externo

- 1x Pinhão interno

- 1x Coroa interna

- 1x Coroa externa

- 1x Mancal do volante

- 1x Mancal intermediário

- 1x Mancal do eixo inferior

Todas as peças citadas previamente estão indicadas na Figura 2-5, que também podem ser visualizadas de outro ângulo na Figura 2-4.

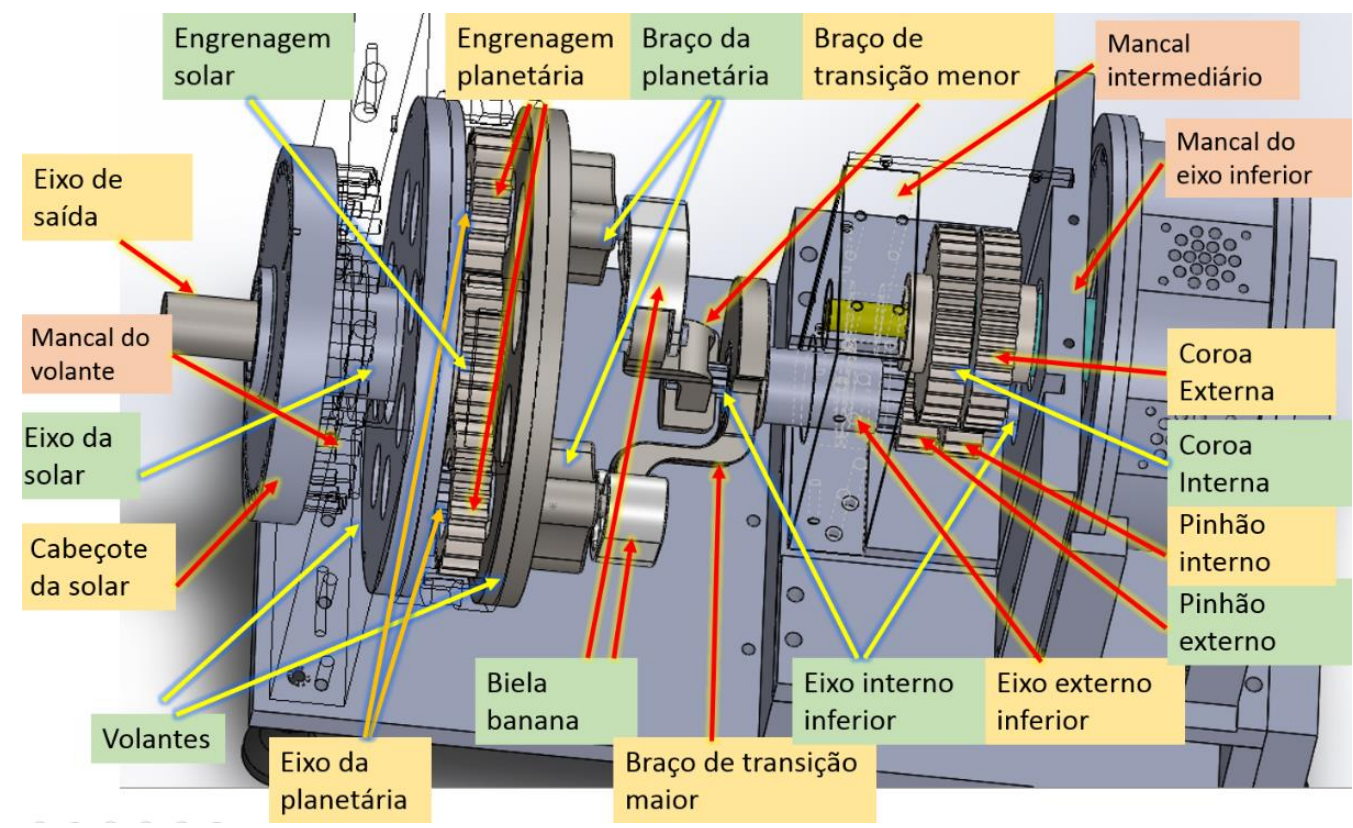

Figura 2-5 Componentes do DVDM. O mancal do volante e o mancal intermediário estão ocultos para facilitar a visualização. Modelo em software SolidWorks

Para compreender o funcionamento do Mecanismo de Acionamento de velocidade variável é necessário que se entenda que todas as peças estão conectadas por engrenamento, estrias ou rolamentos, de forma sequencial e encadeada. A Figura 2-6 mostra um fluxograma com a sequência pelo qual é transferido o 
movimento do eixo de saída (eixo primário) até as engrenagens maiores, que estão acopladas aos rotores sobre os quais os pistões são montados.

O eixo de saída, apoiado sobre rolamentos ao eixo da solar, é encaixado ao volante com auxílio de estrias. O volante é composto por dois discos volantes e um cilindro vazado, unidos por parafusos. Um dos discos é montado ao eixo de saída com estrias, enquanto que o outro disco volante é apoiado sobre o eixo da solar com ajuda de rolamento. Nos dois discos do volante existem rebaixos onde são montados rolamentos para apoiar o eixo da planetária. Cada eixo da planetária possui dois conjuntos de estrias. Um conjunto serve para montar a engrenagem planetária enquanto que o outro, para montar o braço da planetária. As engrenagens planetárias, que são móveis, estão engrenadas à engrenagem da solar, que é fixa.

A engrenagem solar é montada sobre estrias ao seu eixo, que é conectado ao cabeçote da solar, também utilizando estrias. O cabeçote da solar possui uma fixação ajustável parafusada ao mancal do volante, de forma que é possível estabelecer uma posição angular arbitrária para a engrenagem solar, que é estacionária. A variação da posição angular da engrenagem solar resulta numa mudança da posição do ponto morto superior dentro da câmara do Sistema de Conversão de Energia.

O braço da planetária é montado ao eixo da planetária sobre estrias, enquanto que o pino excêntrico do braço fica a uma distância entre eixos, em relação ao eixo da planetária, de exatamente o raio do círculo primitivo da engrenagem planetária, de forma que o pino efetue um movimento de curva epiciclóide, por estar exatamente sobre o círculo primitivo da engrenagem planetária.

Um lado da biela banana é montado sobre rolamentos montados ao pino excêntrico do braço da planetária, enquanto que o outro lado da biela é montado sobre rolamentos ao braço de transição da redução, podendo ser o interno ou externo.

O braço de transição menor é montado sobre estrias ao eixo inferior interno, que é conectado por estrias ao pinhão interno da redução, que está engrenado à coroa externa, conectado por estria ao rotor externo. O eixo inferior interno é montado sobre rolamento apoiado ao eixo inferior externo, e também ao mancal do eixo inferior.

O braço de transição maior é montado sobre estrias ao eixo inferior externo, que é conectado por estrias ao pinhão externo da redução, que está engrenado à 
coroa interna, conectada por estrias ao rotor interno. O eixo inferior externo é montado sobre rolamentos apoiados ao mancal intermediário.

Deve-se notar, na Figura 2-6, que os componentes desde o eixo de saída até os braços da planetária funcionam com velocidade angular uniforme, e a apenas a partir da biela banana que o movimento das peças deixa de ser uniforme.

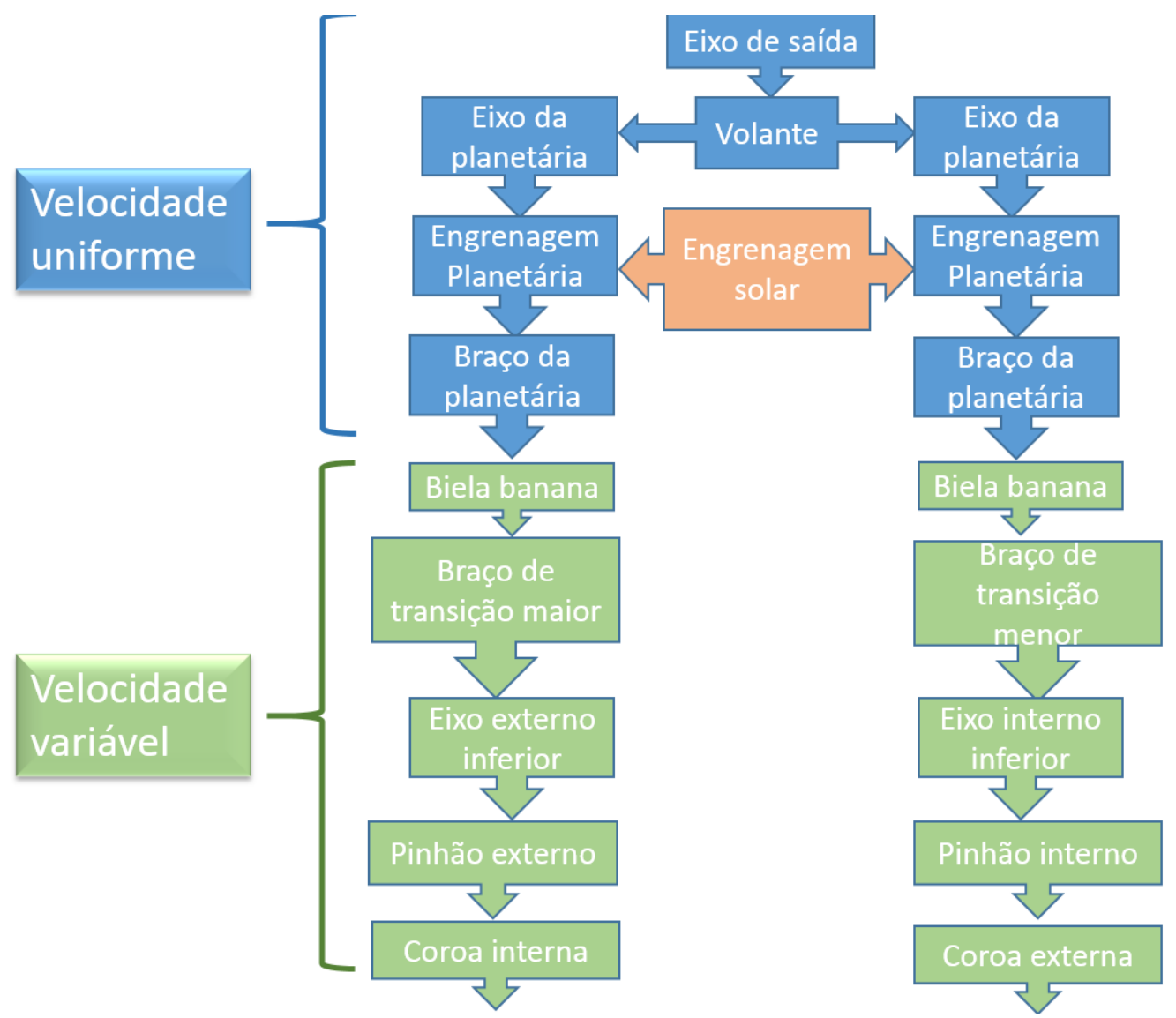

Figura 2-6 Fluxograma da cadeia de movimento dos componentes do DVDM, considerando acionamento a partir do eixo de saída. OBS: A engrenagem solar é o único componente estático.

\subsection{2.}

\section{Princípio de funcionamento do DVDM}

Antes de prosseguir para a descrição do funcionamento do Sistema de conversão de energia (ECS), é interessante explicar como que se fornece o movimento diferencial dos pistões.

É preciso relembrar que no motor Kopelrot ambos os rotores funcionam em movimento variável, com duas "paradas" e "acelerações" por volta de rotor. O Mecanismo de Acionamento de Velocidade Diferencial (DVDM) do motor 
Kopelrot possui algumas semelhanças com o motor Virmel e Wittry (Melvin, 1967; Wittry, 1995). Todos eles possuem um sistema planetária, com braços da planetária, biela e braço de transição. No entanto, as engrenagens planetárias do Kopelrot são idênticas à engrenagem solar, enquanto que na maioria dos motores TRPE as planetárias possuem a metade do número de dentes da engrenagem solar. Além disto, o eixo do Sistema de Conversão de Energia é independente do eixo de saída do motor, ou seja, não existe nenhum tipo de ligação mecânica relativa entre rotores e eixo de saída.

No entanto, a relação de dentes de 1:2 das planetárias para a solar é necessária para que os braços das planetárias executem um movimento epiciclóide nefróide. Esse movimento em conjunto com bielas e braços dos rotores, fazem com que os pistões executem um movimento de desaceleração e aceleração (cat-and-mouse), duas vezes por revolução dos rotores. Assim, combinando-se a aceleração e desaceleração alternada dos rotores e pistões, cada câmara de trabalho expande e reduz duas vezes por volta de rotor. Dessa forma é possível replicar o ciclo de processos de um motor alternativo de quatro tempos em um motor TRPE.

Lembrando que uma curva epiciclóide é uma curva cíclica definida por um ponto de uma circunferência que rola sem deslizar sobre um círculo diretor. Nefróide é uma epiciclóide quando a razão entre o raio do círculo diretor e o círculo que move é de 2, e cardioide quando o raio do círculo diretor é igual ao círculo móvel. Essas curvas podem ser vistas na Figura 2-7, onde k é a relação entre o raio do círculo diretor e o raio da circunferência rolante. Na prática essas curvas são obtidas pelo movimento do braço da planetária, cuja distância do centro do seu pino ao centro da engrenagem equivale ao raio do círculo primitivo da planetária, que "rola" sobre o círculo primitivo da engrenagem solar, da mesma forma que o círculo que traça a curva epiciclóide rola sobre o círculo diretor sem deslizar. 


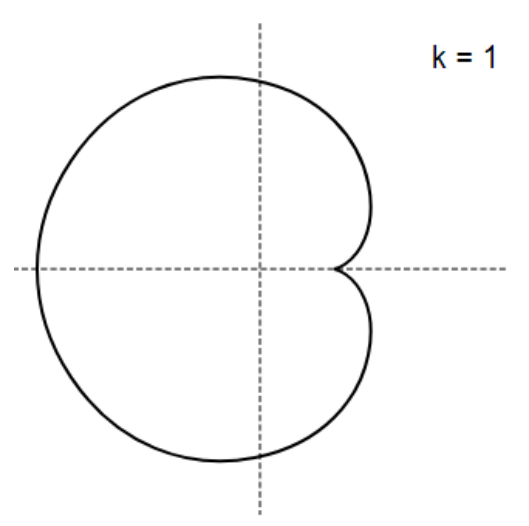

Cardioide

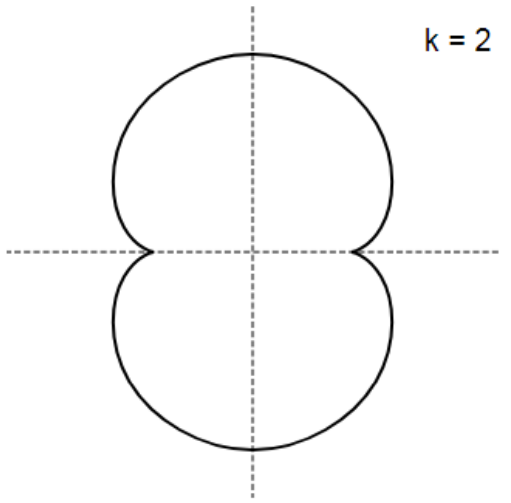

Nefroide

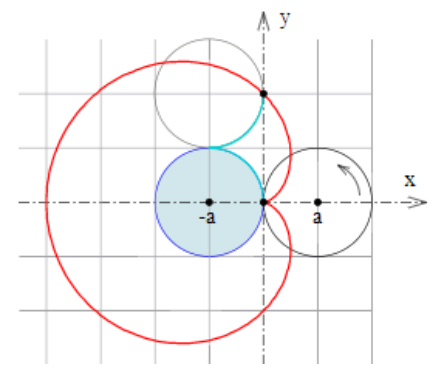

Figura 2-7 Curvas epicicloides na parte superior, e na parte inferior uma demonstração da formação de uma curva cadioide a partir do rolamento de um círculo sobre um círculo diretor de mesmo raio.

É de conhecimento comum entre os inventores de motores TRPE que a relação da redução das engrenagens planetárias e solar é diretamente proporcional ao número de pistões por rotor, ou seja, para um pistão por rotor, redução 1:1, para dois pistões, 2:1, para três pistões $3: 1$, e assim por diante. Essa regra pode ser quebrada caso a redução seja realizada entre os rotores e os braços dos rotores, ou seja, entre o mecanismo de acionamento da velocidade diferencial e o sistema de conversão de energia, que é o caso do motor Kopelrot. Por esse motor apresentar um sistema inovador de mudança de taxa de compressão (descrito na subseção 2.5), necessitando que o Sistema de Conversão de Energia seja deslocado horizontalmente em relação ao eixo de saída, caso a redução de 2:1 fosse realizada pelas planetárias, não seria possível deslocar o ECS lateralmente para obter o efeito de variação da taxa de compressão, (Kopelowicz, 2012).

No motor Kopelrot, as planetárias e solar possuem relação de 1:1, e a redução é realizada após a conversão do movimento uniforme em movimento variável. Assim, transforma-se o movimento variável de uma parada por rotação, fornecida 
pela relação 1:1 do sistema planetária, em um movimento de duas paradas por rotação, graças a redução 2:1.

Ou seja, o movimento epiciclóide formado pelos braços das planetárias do motor Kopelrot representa uma epiciclóide cardioide, com apenas um ponto de inflexão, mas a redução 2:1 entre o DVDM e o ECS faz com que o mecanismo de velocidade diferencial aparentasse possuir um sistema planetária formando uma epiciclóide nefróide. Na Figura 2-8 o movimento cardioide dos braços das planetárias pode ser observado. Note que o ponto de inflexão ocorre no ponto superior vertical, representado pelo braço da planetária superior na posição "E" da Figura 2-8.

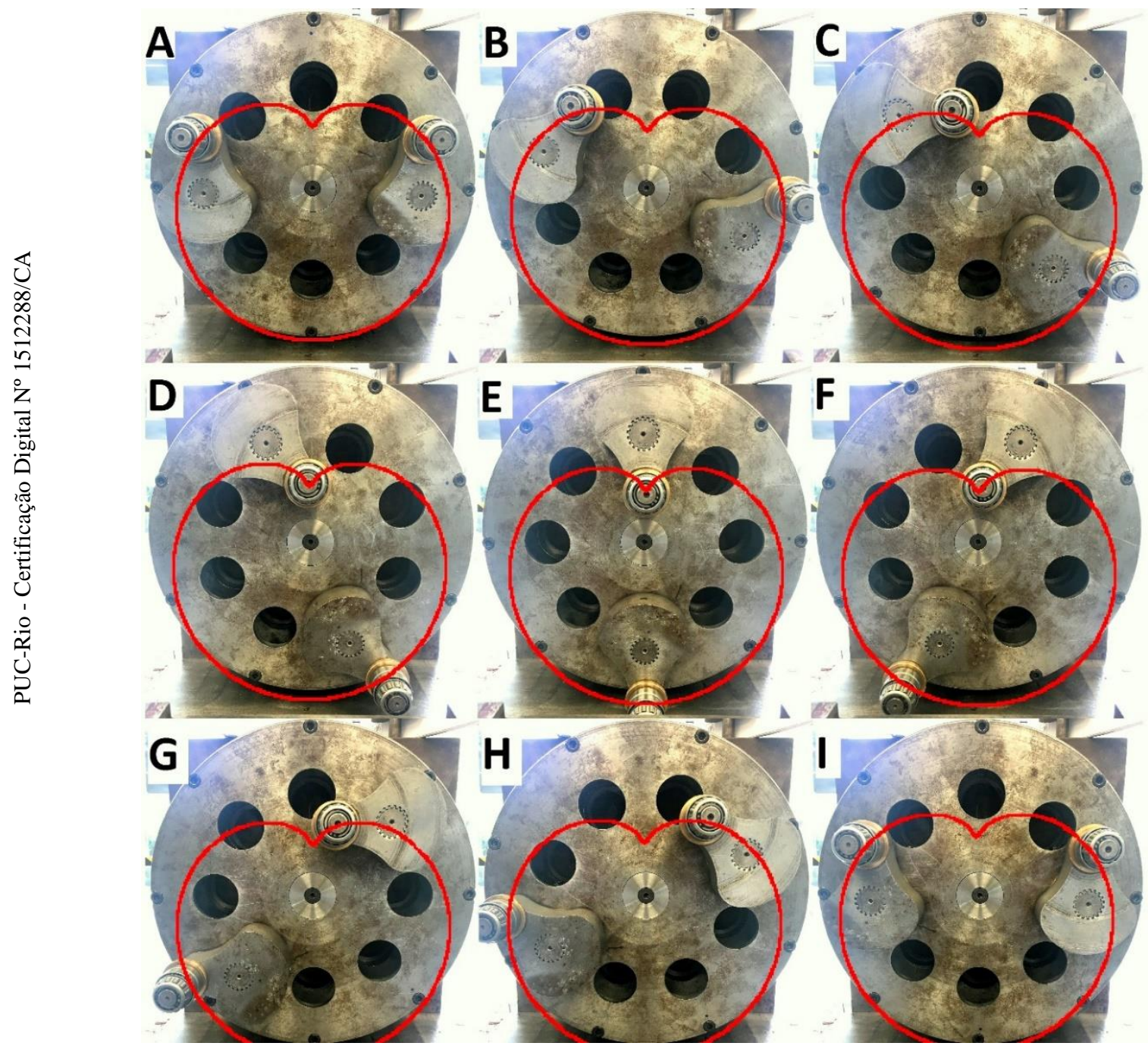

Figura 2-8 Movimento epicicloide dos braços da planetária (o cardioides desenhados sobre as imagens serve para auxiliar o entendimento).

Como pode ser observado nas Figura 2-1, Figura 2-2 e Figura 2-4, o eixo de saída é concêntrico aos eixos inferiores (quando a excentricidade é nula), sobre os 
quais estão montados os braços de transição. Assim, quando o volante gira em conjunto com os braços da planetária, o pino excêntrico desse braço, que forma a curva cardioide, tem seu ponto de aproximação máxima ao eixo central em seu ponto de inflexão, representado pelo braço da planetária no instante "E" da Figura 2-8. Próximo ao ponto de inflexão, a biela banana e o braço de transição estão em sua posição onde o angulo formado entre eles é o mínimo possível, tanto antes quanto depois do ponto de inflexão, e é nesse instante do movimento que ocorre a "parada" do rotor relacionado ao braço que está no ponto de inflexão, e consequentemente a parada dos pistões fixados a tal rotor. Esse não é um movimento trivial, e por se tratar de várias peças movendo-se simultaneamente, a Figura 2-9 ajuda a compreensão desse movimento de aproximação do ponto de inflexão. Para entender o movimento de desaceleração, parada e aceleração do rotor, que está conectado ao braço de transição através da redução, tal efeito pode ser observado no braço de transição maior da Figura 2-9. Pode-se notar que o braço de transição maior reduz sua rotação nos instantes referentes posição C,D,E e F da Figura 2-9, indicado pela seta inferior direita, justamente quando o braço da planetária, relacionada ao braço de transição maior e indicado pela seta superior esquerda, se encontra próximo à posição superior do ponto de inflexão do cardioide, mostrado anteriormente no instante "E” da Figura 2-8, e no gráfico da Figura 2-7. Para uma melhor visualização, a Figura 2-10 mostra uma ampliação da Figura 2-9, focado no conjunto de braços e biela. 


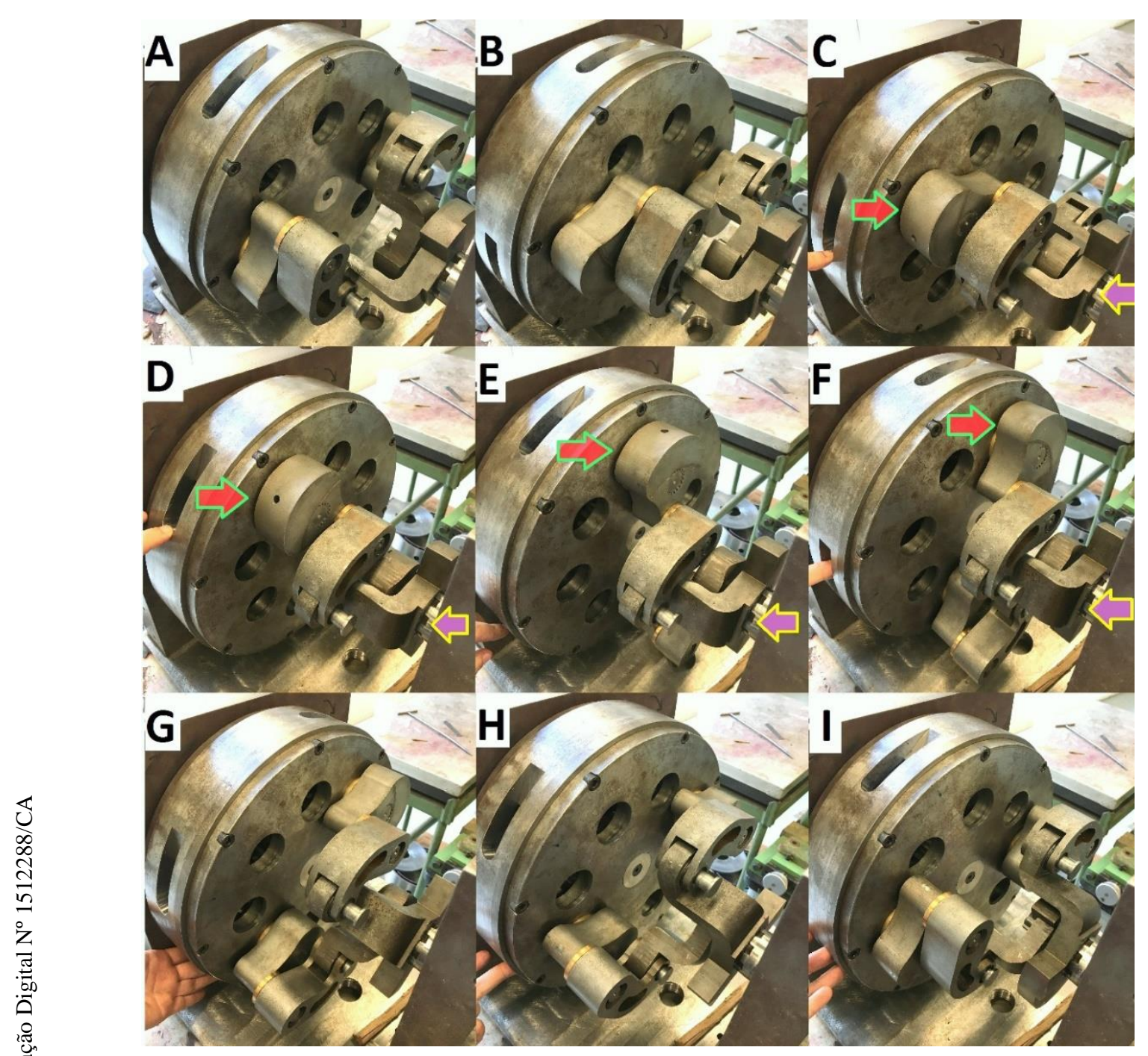

Figura 2-9 Movimento do mecanismo de acionamento de velocidade diferencial para meia volta do volante. 


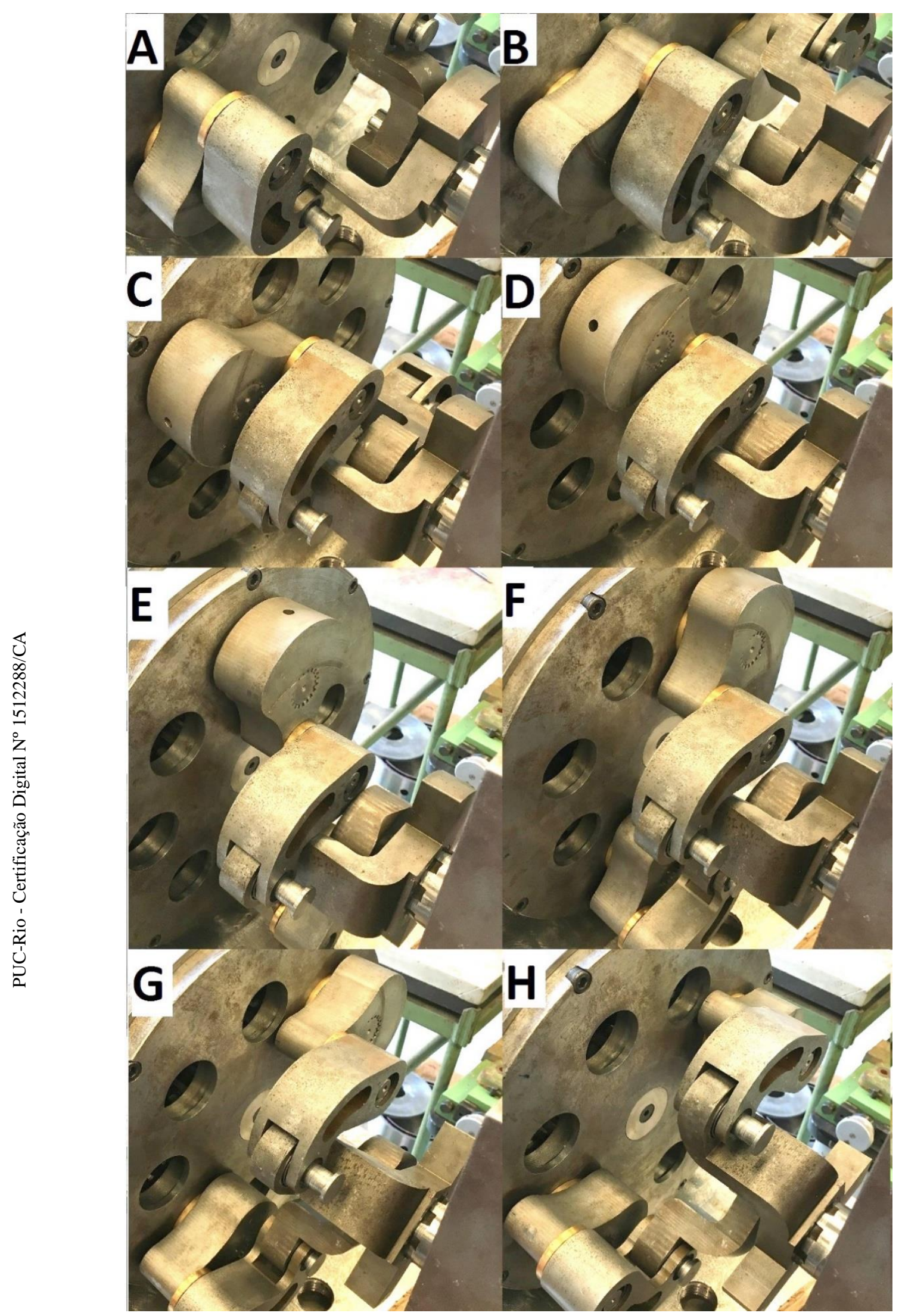

Figura 2-10 Ampliação do conjunto braço planetária, bela e braço de transição.

Conhecendo-se o funcionamento do Mecanismo de Acionamento de Velocidade Diferencial (DVDM), compreende-se o comportamento e o movimento 
do braço de transição e seus ciclos de desaceleração, parada e aceleração. Por estar conectado aos rotores do Sistema de Conversão de Energias (ECS) através de uma redução $2: 1$, é de se esperar que o movimento dos rotores seja a metade do movimento dos braços de transição, com o mesmo comportamento padrão de desaceleração, parada e aceleração.

\section{3.}

\section{Sistema de Conversão de Energia (ECS)}

Como explicado anteriormente, o ECS é toda a parte do motor na qual ocorre a queima de combustível, geração de trabalho e a circulação de fluido de arrefecimento.

\subsection{1.}

\section{Componentes do ECS}

O ECS é composto pelas seguintes peças que podem ser visualizadas nas Figura 2-11 eFigura 2-12.

- $4 x$ Pistões

- 8x Tampas dos pistões

- 1x Rotor Interno

- 1x Rotor Externo

- 1x Cilindro da câmara

- 1x Tampa interna A

- 1x Tampa interna B

- 1x Tampa intermediária A

- 1x Tampa intermediária B

- 1x Tampa Externa A

- 1x Tampa Externa B

- 1x Mancal-Tampa

- 2x Suporte da Câmara

- 48x Segmentos de Vedação

- $48 x$ Molas da vedação 


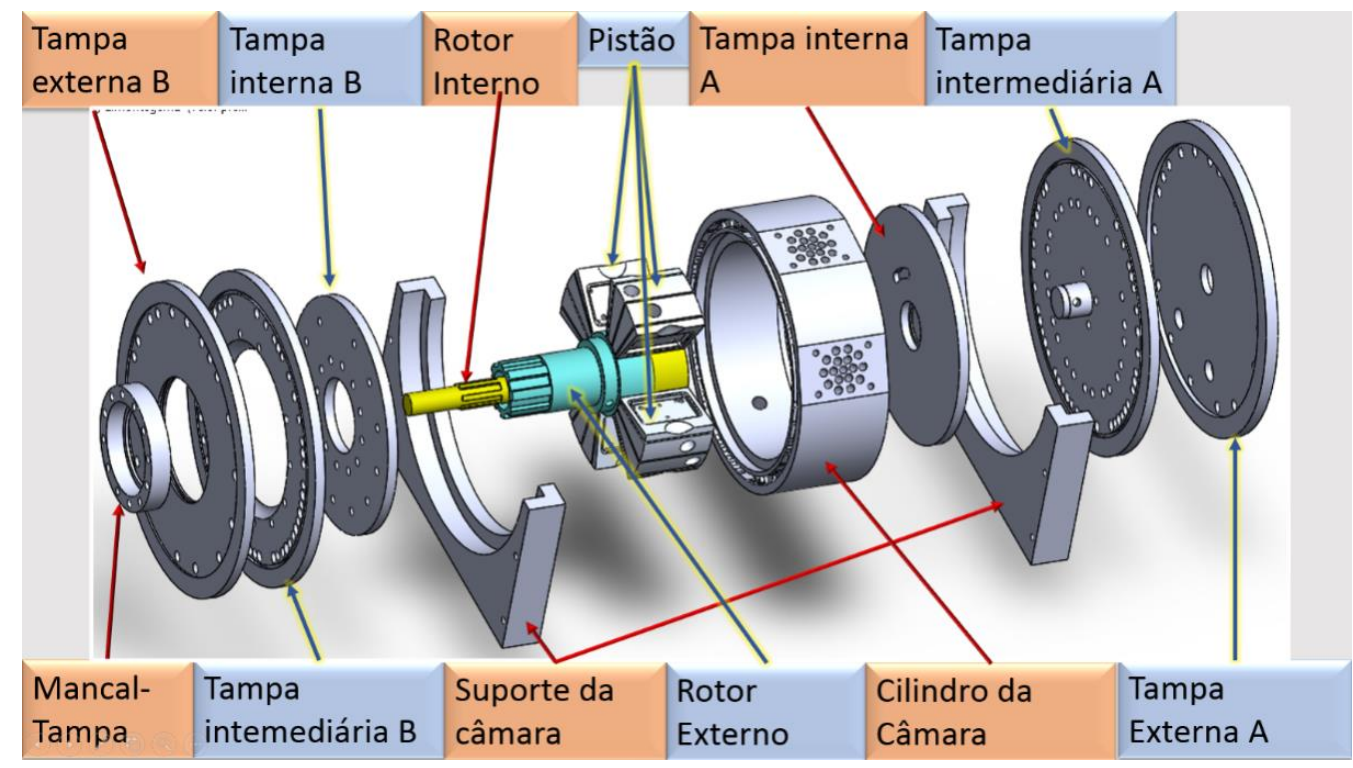

Figura 2-11 ECS em vista explodida. Modelo em software SolidWorks

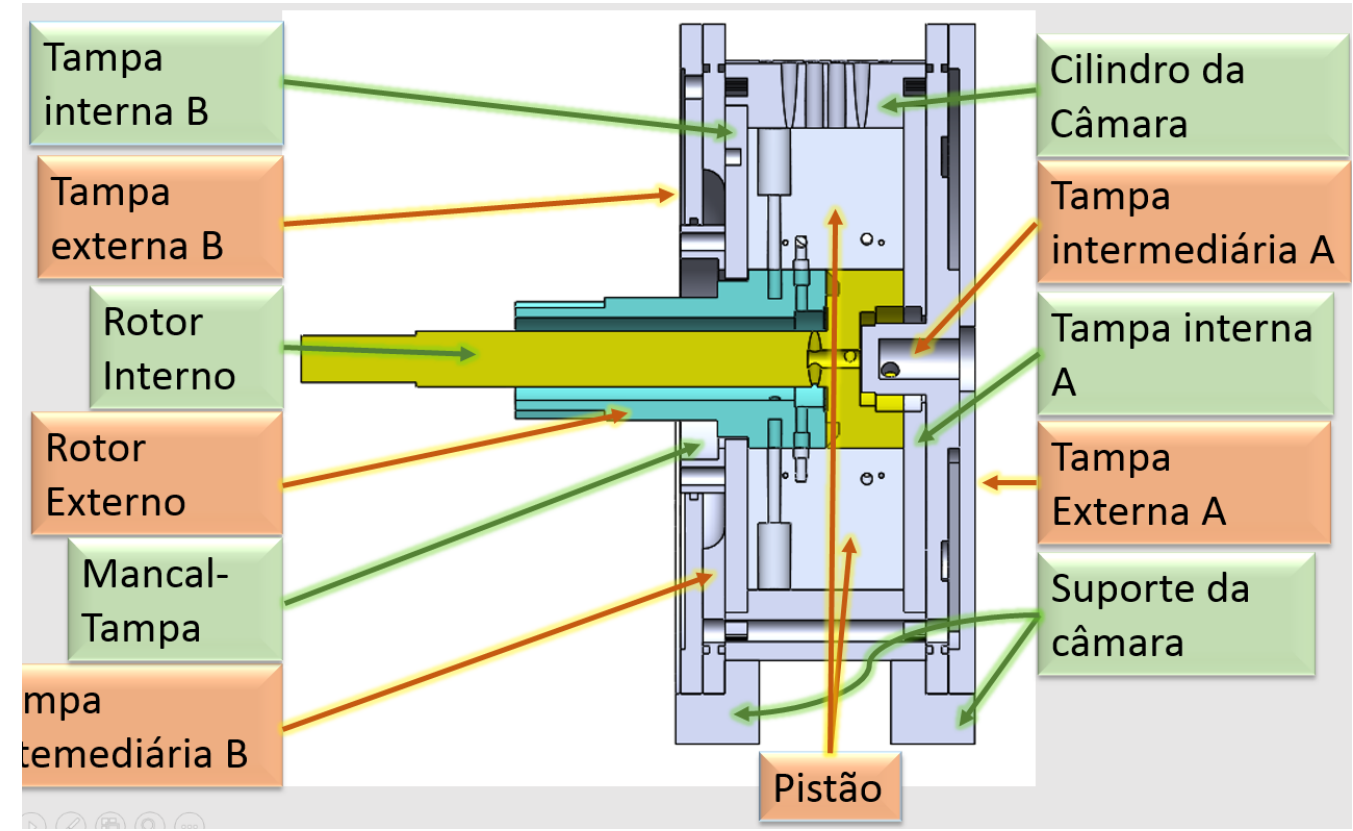

Figura 2-12 ECS em vista de corte. Modelo em software SolidWorks

Todo o conjunto do ECS é apoiado sobre os suportes da câmara (Figura 2-12), que é apoiado sobre a base da câmara (Figura 2-2). O conjunto de cilindro da câmara e tampas laterais são apoiados sobre os dois suportes da câmara. As tampas laterais são presas ao cilindro da câmara utilizando-se parafusos em ambas as laterais da câmara. A tampa interna é parafusada à tampa intermediária, podendo ter sua posição angular ajustada com a mudança da posição dos parafusos. O mancal-tampa é parafusado sobre a tampa interna B. 
Os rotores são montados apoiando-se em rolamentos. O rotor externo é apoiado sobre dois rolamentos cônicos, que são montados sobre o mancal-tampa e o mancal do eixo inferior. O rotor interno é apoiado ao mancal intermediário utilizando-se rolamento do tipo cônico. O eixo do rotor interno passa por dentro do rotor externo, e no espaço anular são posicionados dois rolamentos do tipo de esferas, que servem para garantir a montagem radial dos dois rotores. $\mathrm{O}$ rotor interno também possui um rolamento do tipo de esferas montado sobre o ressalto da tampa intermediária. Além disso, um rolamento do tipo axial de esferas é montado entre o rotor interno e externo, de forma a evitar interferência entre os dois rotores.

Ambos os rotores possuem estrias sobre as quais são montadas as engrenagens da redução

Os pistões são fixados aos rotores em posições diametralmente opostas com auxílio de parafusos. As tampas dos pistões, que possuem os canais de circulação de óleo de arrefecimento, são parafusadas sobre os pistões. Cada pistão possui três linhas de vedação, formadas por 4 segmentos de vedação cada, totalizando 12 segmentos de vedação por pistão e 48 segmentos de vedação no total. Para fornecer uma força mínima sobre a vedação de forma a garantir o funcionamento dos segmentos de vedação, tais segmentos são montados sobre molas onduladas linear.

\subsection{2. \\ Princípio de funcionamento do ECS}

Como já foi dito anteriormente, o DVDM fornece um movimento de desaceleração, parada e aceleração para os rotores, sobre os quais estão montados os pistões. No entanto, pelo fato de o movimento variável dos rotores ocorrer fora de fase, existe um movimento relativo entre rotores e pistões. Esse movimento relativo entre pistões resulta em sucessivas aproximações e afastamentos, que alguns inventores nomearam de movimento tesoura, ou movimento cat-and-mouse.

Com o movimento relativo entre pistões, o volume entre os mesmos varia, sendo esse volume a câmara de trabalho onde ocorrem os processos termodinâmicos do motor Kopelrot. A razão do volume máximo sobre o volume mínimo é conhecido como taxa de compressão, e nos motores rotativos do tipo TRPE é calculado pela seguinte relação (Guarato et al., 2015): 


$$
r_{c}=\frac{\varphi_{\max }}{\varphi_{\min }}
$$

Sendo $r_{c}$ a taxa de compressão, $\varphi_{\max }$ o ângulo máximo entre pistões e , $\varphi_{\text {min }}$ o ângulo mínimo entre pistões.

\subsection{3.}

\section{Características da câmara}

A parte interna do ECS, onde ocorre a combustão, é formada por quatro câmaras, delimitadas pela superfície plana dos pistões, a superfície cilindrica convexa dos rotores, a superfície plana das tampas internas e da superfície interna do cilindro da câmara. Essas características podem ser notadas na Figura 2-13.

Ao contrário dos motores alternativos, o motor Kopelrot assim como muitos motores rotativos, não possui válvulas de admissão e exaustão e sim janelas de admissão e exaustão, com maior área de seção de escoamento e menor perda de carga. As janelas de admissão, exaustão, furo para a vela de ignição e rebaixo do ciclo Miller/Atkinson (explicado na subseção 2.7) podem ser vistos na Figura 2-14.

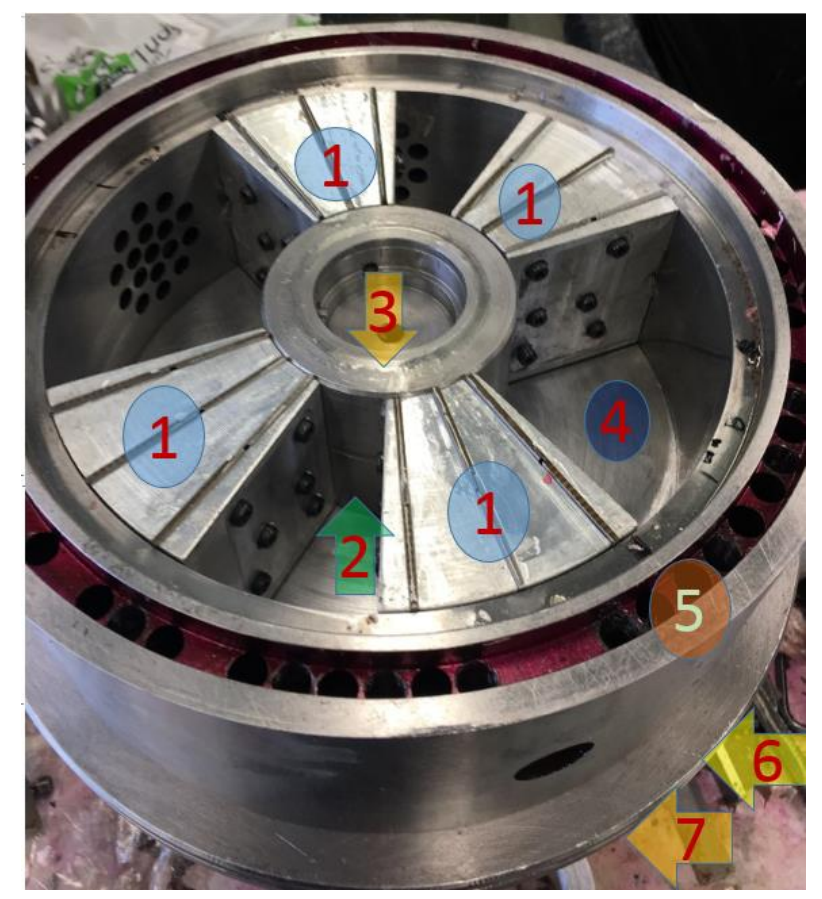

Figura 2-13 (1) Pistões, (2) rotor interno, (3) rotor externo, (4) tampa interna B, (5) cilindro da câmara, (6) tampa intermediária B e (7) tampa externa B, montados sobre bancada. 


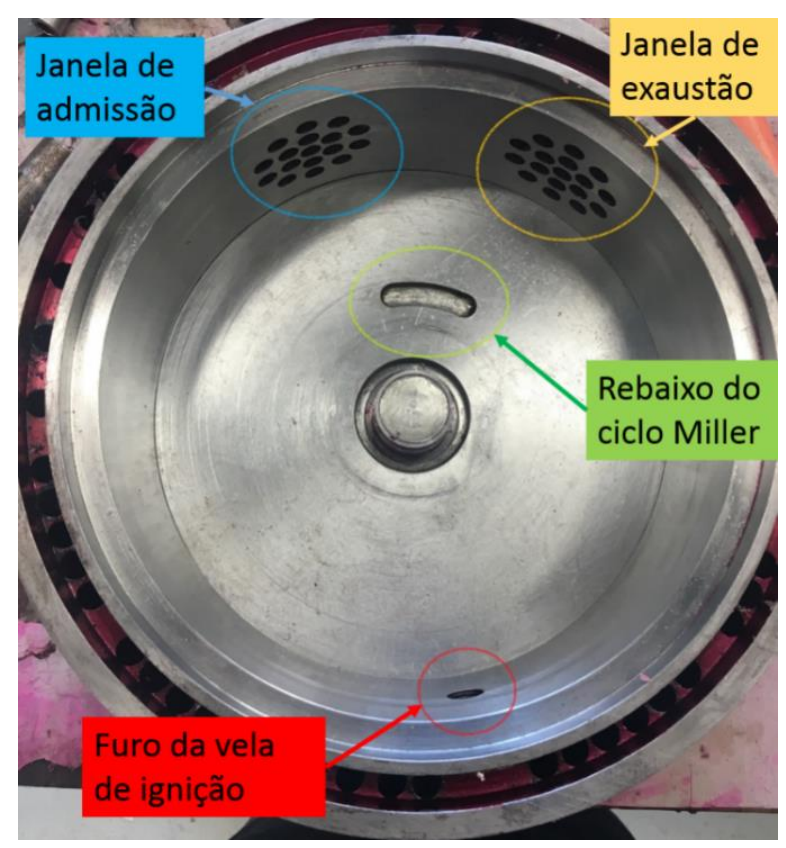

Figura 2-14 Cilindro da câmara com tampa interna $A$ e tampa intermediária $A$ sem pistões e rotores.

\subsection{4. Movimento dos pistões e processos termodinâmicos}

Para que o motor Kopelrot funcione como um motor a combustão de quatro tempos, é necessário que ele execute os processos de admissão, compressão, combustão, expansão e exaustão. Todos esses processos ocorrem a cada duas revoluções do volante em cada uma das quatro câmaras entre pistões do motor, e de forma simultânea em todas as câmaras. Na Figura 2-15 está representado o início da etapa de admissão do motor Kopelrot. Note que as linhas de vedação dos pistões evita que ocorra abertura de passagem direta entre a admissão e a exaustão 


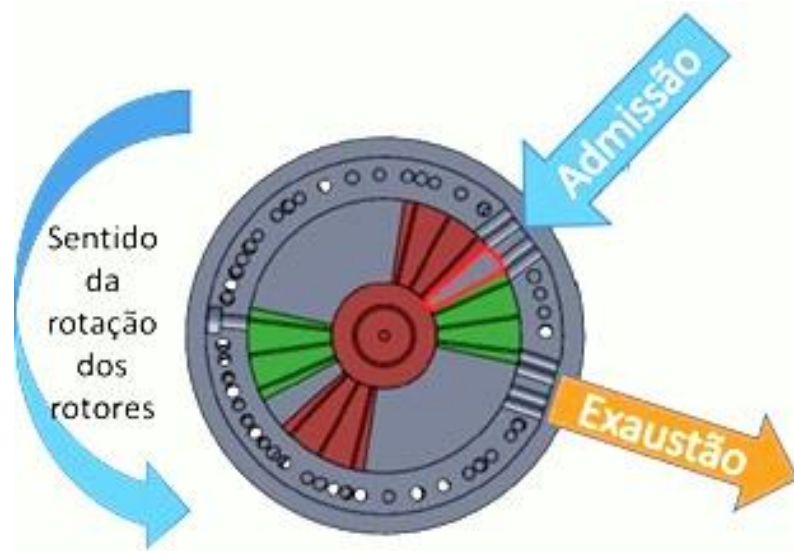

Figura 2-15 Início da admissão da câmara selecionada. Modelo em software SolidWorks

Ao final da admissão, o movimento dos pistões faz com que o volume de gases admitido na câmara seja confinado entre pistões, e devido ao movimento dos pistões o volume é levado para uma região do cilindro da câmara onde não existe passagem para a janela de admissão. Ao final da admissão inicia o processo de compressão. Essa etapa pode ser vista na Figura 2-16.

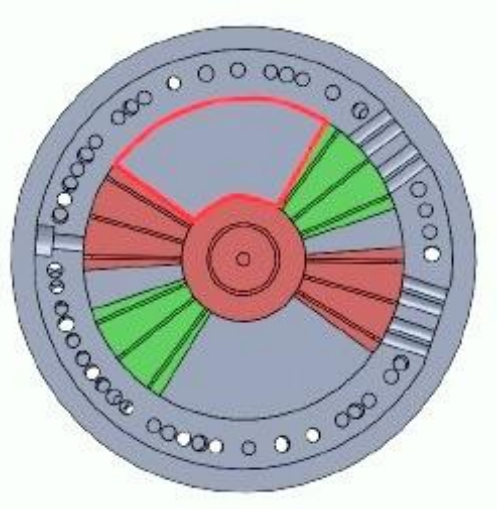

Figura 2-16 Final da admissão e início da compressão da câmara selecionada. Modelo em software SolidWorks

Ao final do processo de compressão os pistões posicionam-se de forma que a vela de ignição esteja entre os pistões adjacentes. Ou seja, o ponto morto superior desse motor deve ocorrer na posição onde está localizada a vela de ignição, como mostra na Figura 2-17. Após a combustão tem início o processo de expansão. 


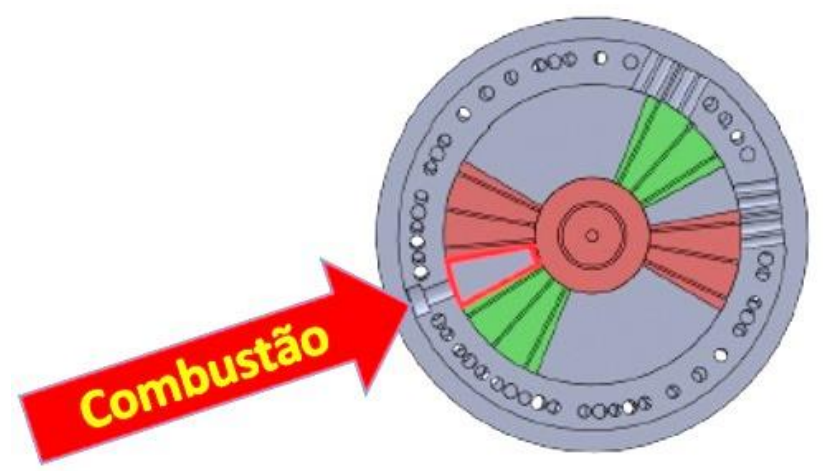

Figura 2-17 Final da compressão, combustão e início da expansão da câmara selecionada. Modelo em software SolidWorks

Após a combustão os pistões afastam-se para a etapa do processo de expansão que pode ser visto na Figura 2-18. Ao final da expansão o movimento dos pistões faz com que o volume de mistura de gases tenha acesso à janela de exaustão.

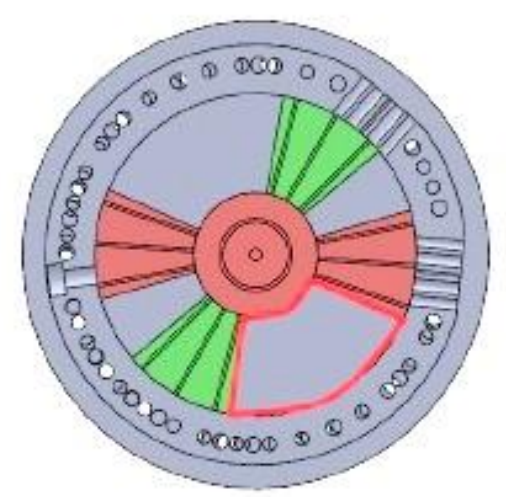

Figura 2-18 Final da expansão e início da exaustão da câmara selecionada. Modelo em software SolidWorks

Na Figura 2-19 pode-se visualizar o gráfico do movimento referente a dois pistões adjacentes e a distância angular relativa entre eles. Note que o gráfico representa apenas uma revolução dos pistões, enquanto que o eixo de saída efetua duas rotações. 


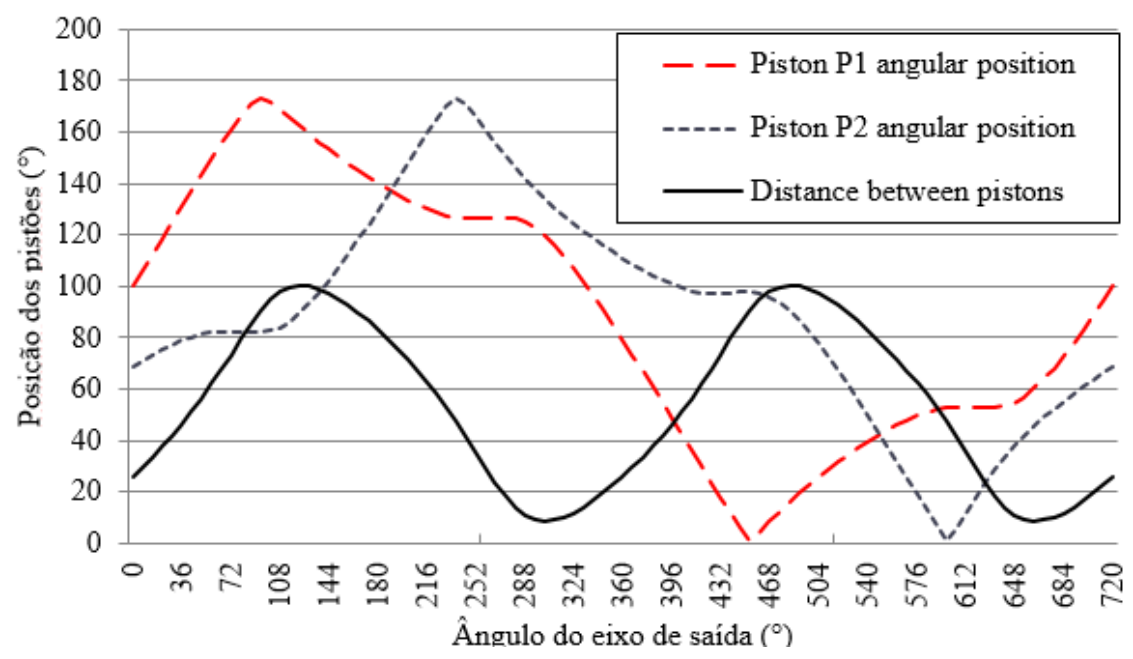

Figura 2-19 Gráfico do movimento entre dois pistões adjacentes P1 e P2 (Guarato et al., 2016).

\subsection{5.}

\section{Segmentos de Vedação}

Para garantir um mínimo de vazamento entre câmaras, cada pistão possui três linhas de vedação posicionadas radialmente, de forma a fornecer uma vedação adequada ao funcionamento do motor. Cada uma dessas linhas de vedação é formada por quatro segmentos de vedação, que funcionam de forma independente apoiados sobre segmentos de mola. A Figura 2-20 mostra a composição da linha de vedação intermediária do pistão, com cada um de seus segmentos de vedação e uma vista em corte do pistão para mostrar sua localização. 


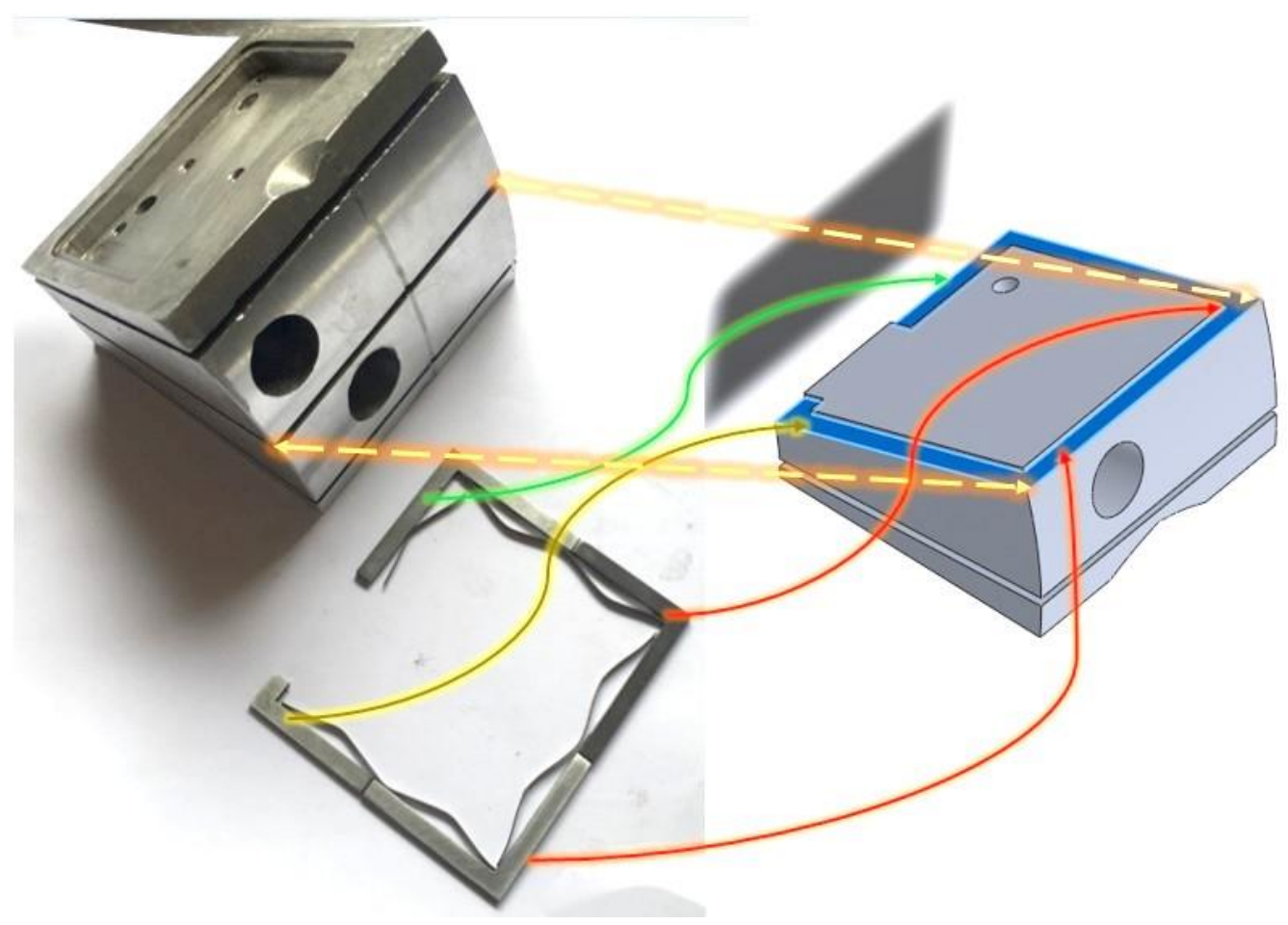

Figura 2-20 Exemplo de uma linha de vedação do pistão. (esq.) ao lado dos 4 segmentos de vedação e suas molas. (dir.) Vista de corte do pistão, em modelo SolidWorks, com destaque para a posição de montagem dos segmentos de vedação.

\subsection{6. \\ Circuito de óleo de arrefecimento}

Para o arrefecimento e lubrificação do motor, o ECS dispõe de dois circuitos de óleo paralelos, um “interno" e outro "externo". O circuito interno é responsável por resfriar os pistões e rotores e lubrificar os rolamentos que apoiam os rotores. $\mathrm{O}$ circuito externo é responsável por arrefecer as tampas laterais e o cilindro da câmara. As passagens de óleo de ambos os circuitos estão explicadas nas Figura 2-21, Figura 2-22 e Figura 2-24. Na parte do circuito interno de óleo referente a passagem por dentro dos pistões, o óleo escoa próximo a face dos pistões que está em contato com a frente de chama. Para aumentar a troca de calor nos canais internos dos pistões, estes são formados por tampas removíveis e pinadas, de forma a aumentar a área de troca de calor por convecção forçada. Esses canais pinados estão mostrados na Figura 2-23. 


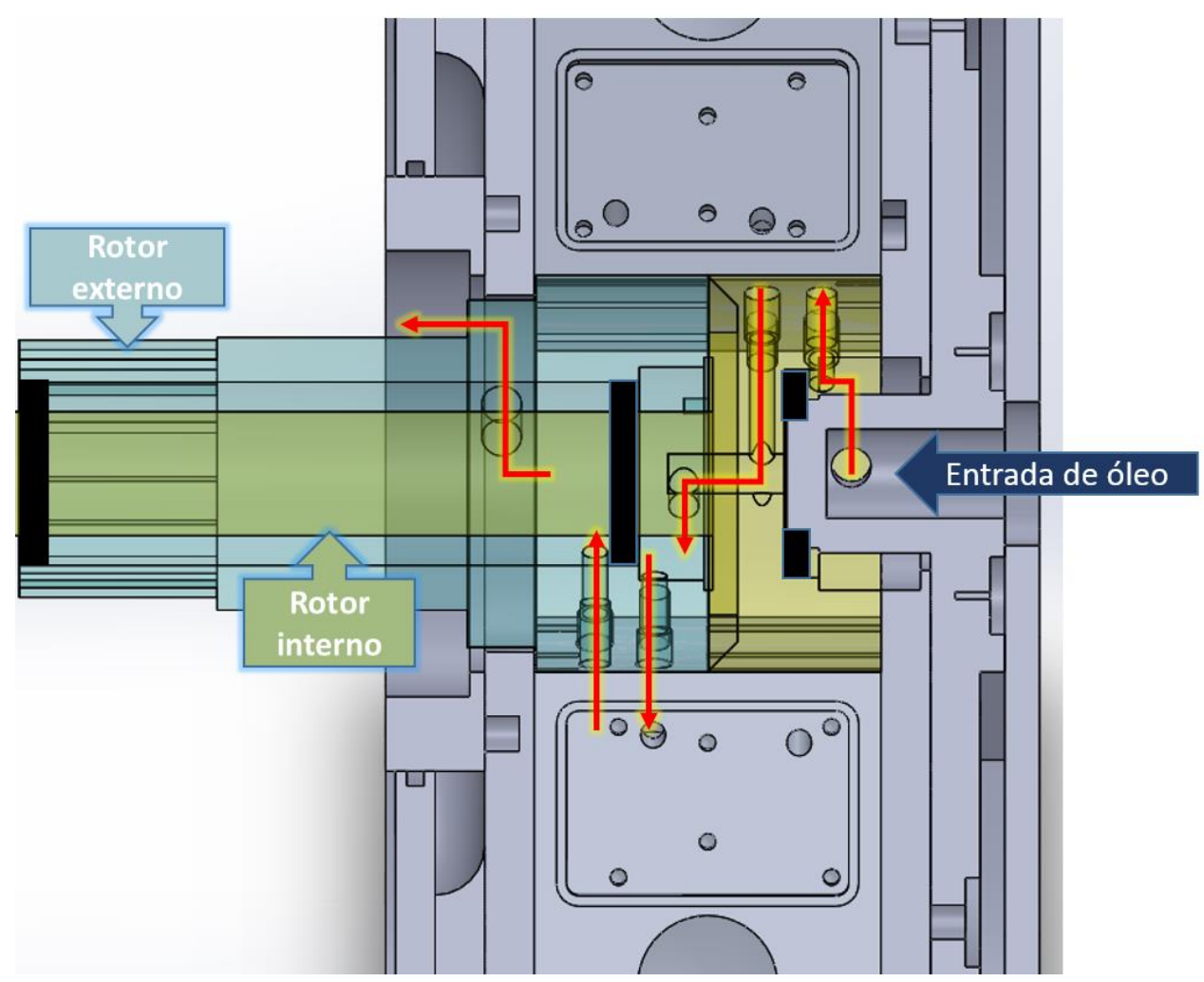

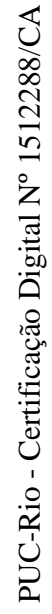

Figura 2-21 Passagem de óleo interna pelos rotores. Modelo em software SolidWorks
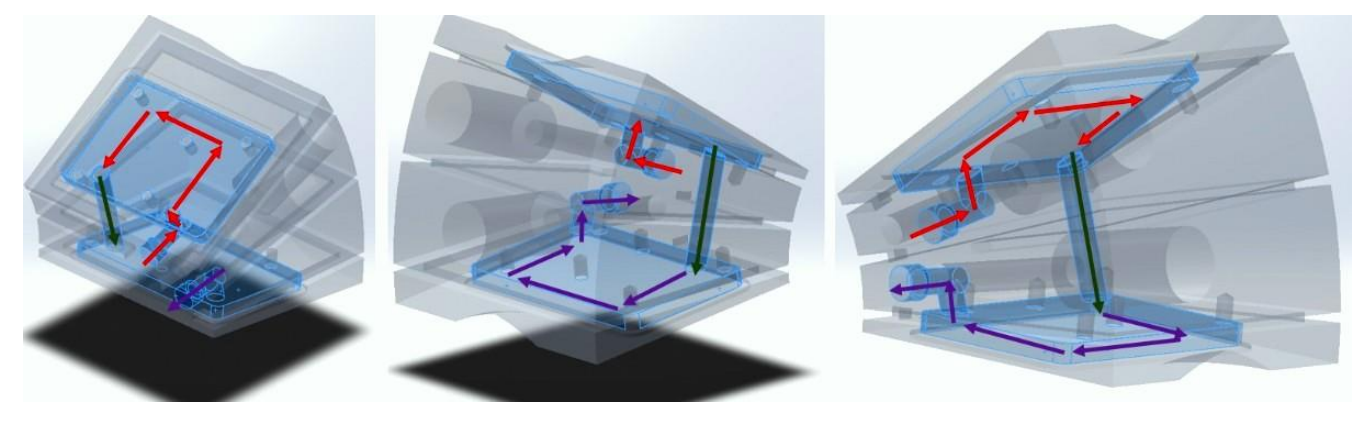

Figura 2-22 Passagem de óleo interna por um dos pistões. Modelo em software SolidWorks
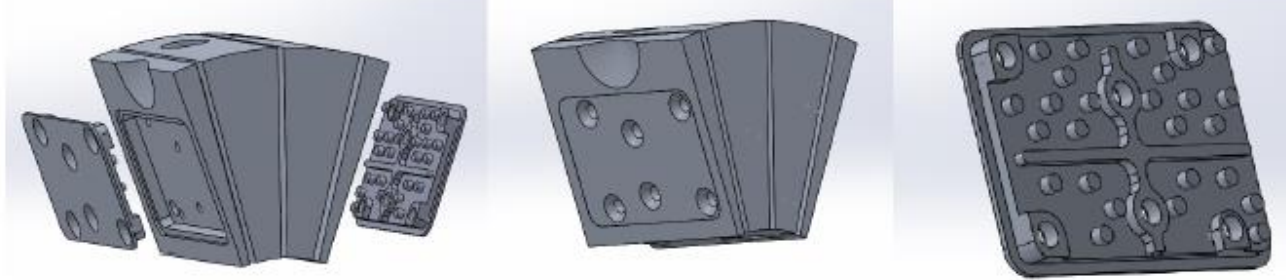

Figura 2-23 Tampas de óleo pinadas para aumentar a superfície de troca de calor. Modelo em software SolidWorks 

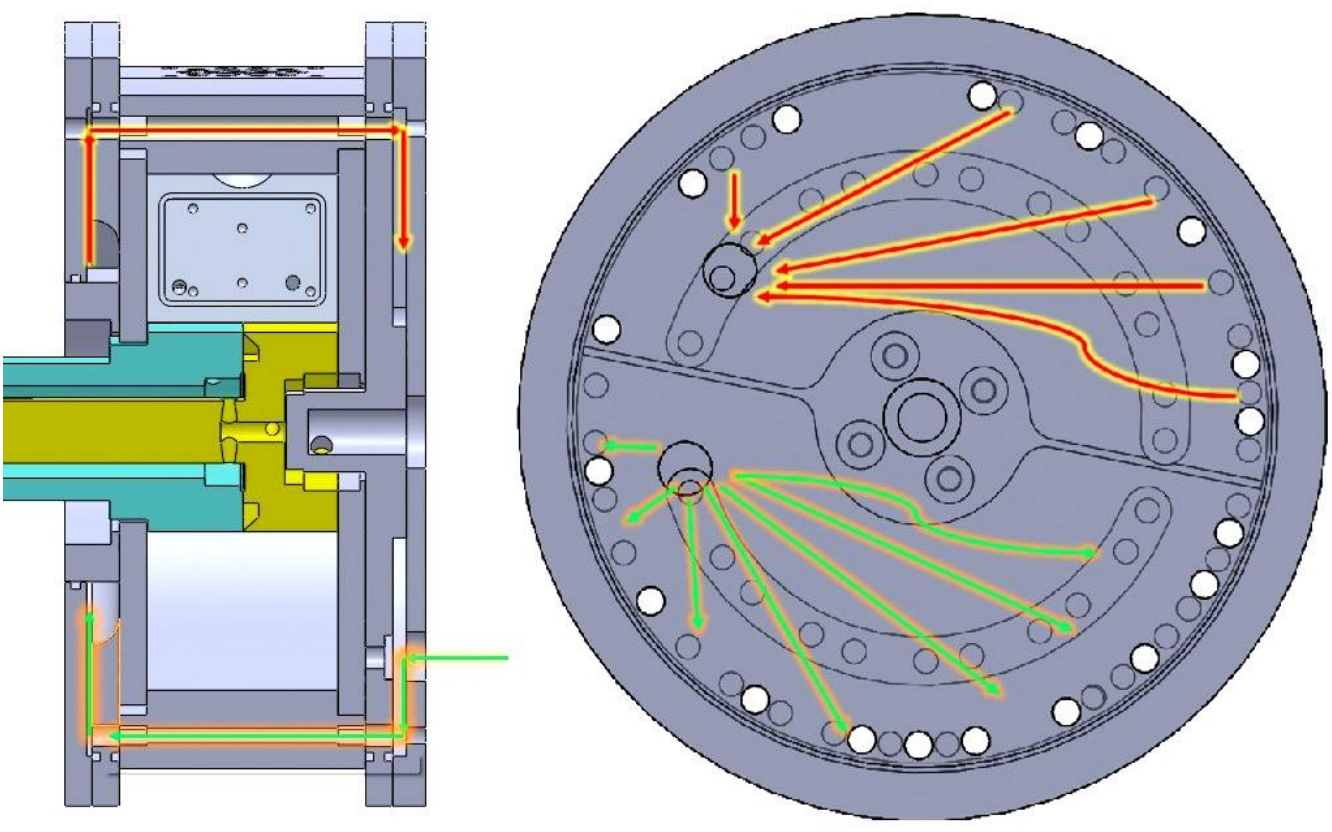

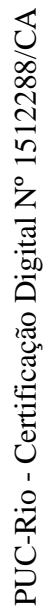
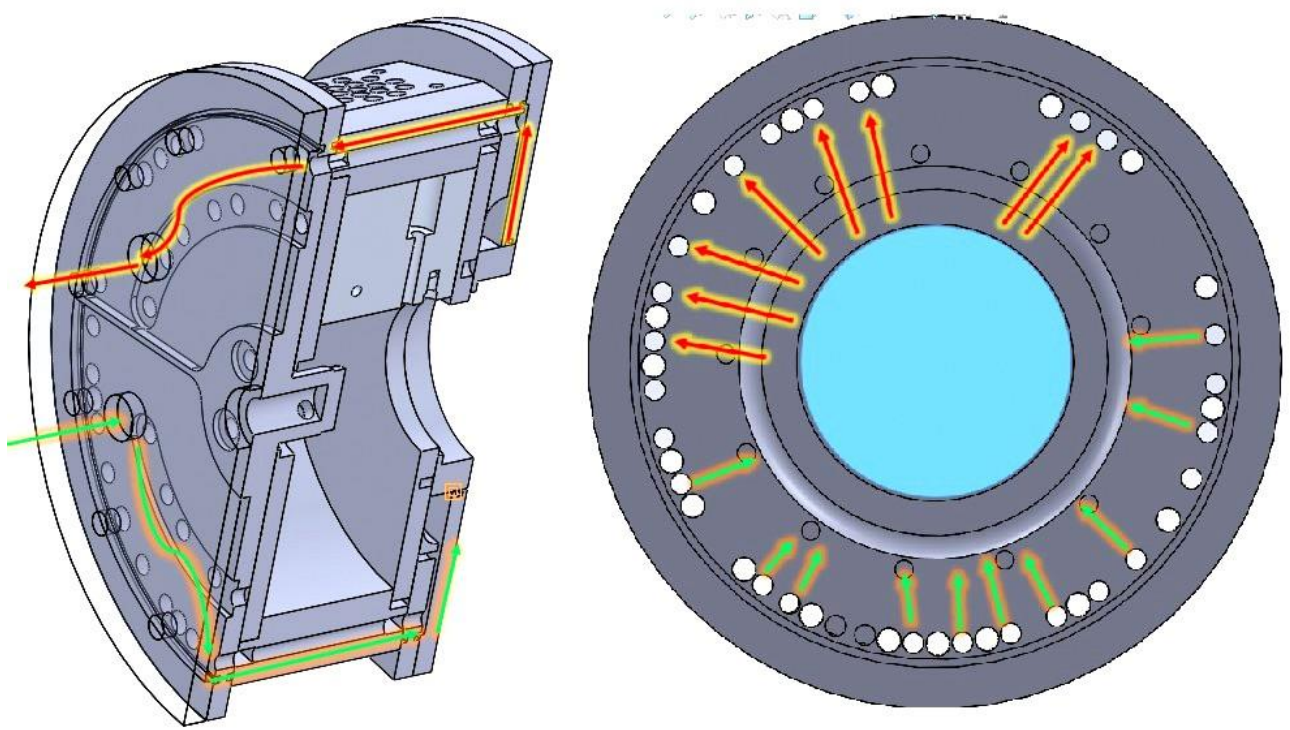

Figura 2-24 Circuito externo de óleo. Modelo em software SolidWorks

\section{4.}

\section{Sustentação do motor}

A sustentação do motor Kopelrot é formada por todas as peças estacionárias que servem de base para os mancais e suporte da câmara para o motor. Tais peças podem ser vistas na Figura 2-25. 


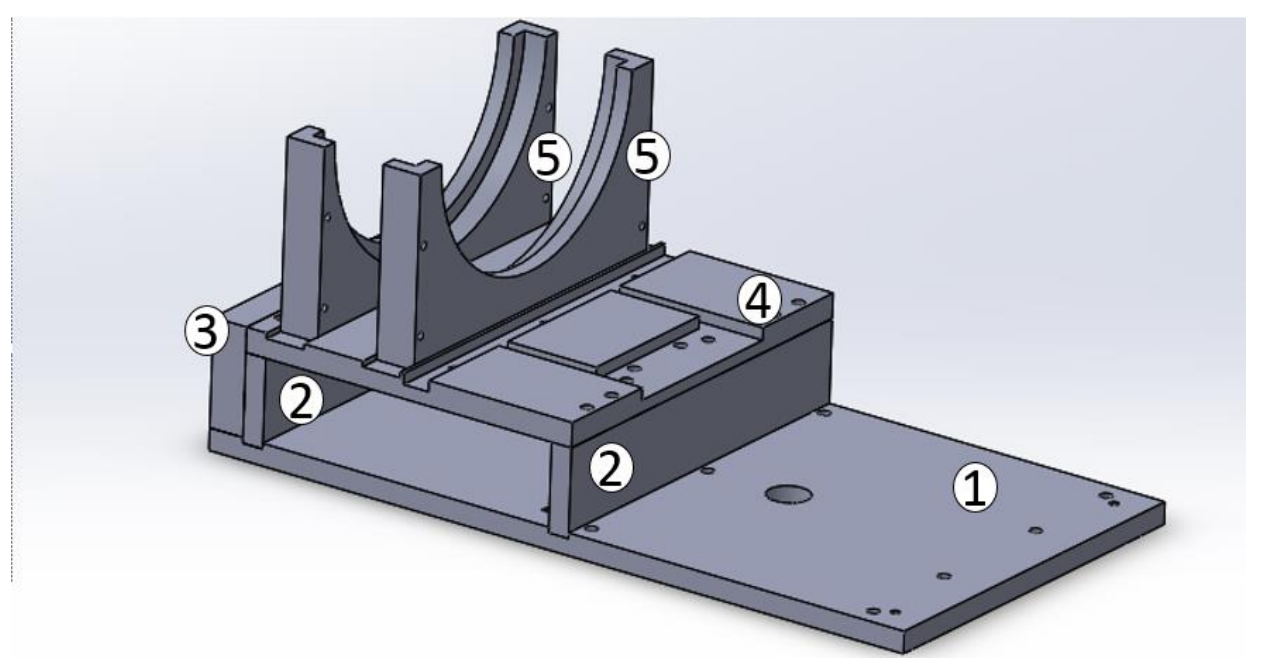

Figura 2-25 Sustentação do motor: 1-Base, 2-Suporte das Bases, 3-Trava,4-Base da Câmara, 5-Suporte da Câmara (incluído no ECS)

\section{5. Sistema de variação da taxa de compressão}

A variação de taxa de compressão do motor Kopelrot é obtida quando se altera a distância horizontal dos eixos inferiores da redução em relação ao eixo de saída (primário). Essa distância é chamada de excentricidade e, para variá-la, é necessário que haja um deslocamento lateral da base da câmara e suporte das bases, mostrados na Figura 2-25.

Ao deslocar lateralmente a base da câmara, toda a redução e ECS movem-se em conjunto. Quando a posição do eixo central dos braços de transição varia em relação ao centro do volante, o efeito desse deslocamento lateral é uma variação do ângulo mínimo e máximo de aproximação entre pistões. Essa variação angular mínima e máxima resulta numa mudança da taxa de compressão do motor Kopelrot.

Na Figura 2-26 está ilustrado como ocorre a variação da excentricidade e seu efeito na aproximação dos pistões no ponto morto superior. No lado esquerdo mostra-se o motor com excentricidade nula, e taxa de compressão de 8,2:1. No lado direito mostra o ECS deslocado lateralmente, com excentricidade de $10 \mathrm{~mm}$, que provoca um aumento de taxa de compressão para 42:1.

Para outros valores de excentricidade a Tabela 2-1 mostra diversos valores de taxa de compressão, ângulo mínimo e máximo entre pistões, volume deslocado e curso em relação a diferentes excentricidades. 
Excentricidade $=0 \mathrm{~mm}$

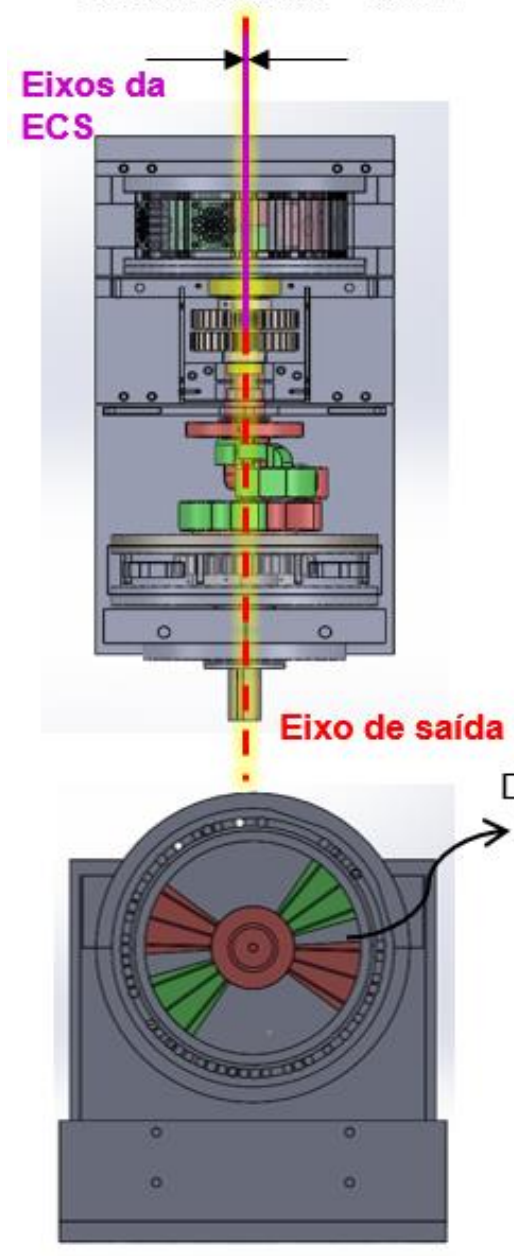

\section{Excentricidade $=10 \mathrm{~mm}$}

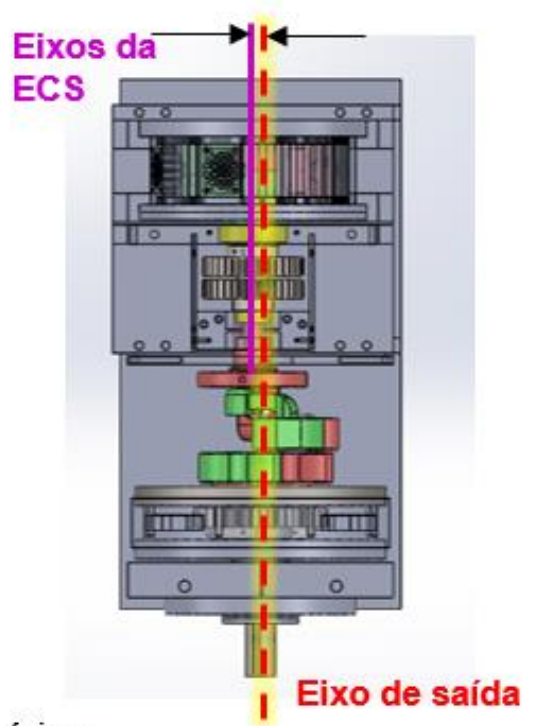

Distância mínima entre pistões

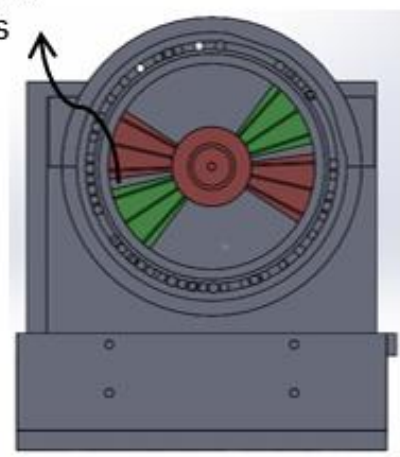

Figura 2-26 Taxa de compressão variável: (esq.) rc= 8,2 e (dir.) rc=41,99. (Guarato et al., 2016).

Tabela 2-1 Variação de excentricidade (Guarato et al., 2016).

\begin{tabular}{|c|c|c|c|c|c|}
\hline $\begin{array}{c}\text { Excentricidade } \\
(\mathrm{mm})\end{array}$ & $\begin{array}{c}\text { Ângulo mín. } \\
\left({ }^{\circ}\right)\end{array}$ & $\begin{array}{c}\text { Ângulo máx. } \\
\left({ }^{\circ}\right)\end{array}$ & Curso $\left(^{\circ}\right)$ & $\begin{array}{c}\text { Taxa de } \\
\text { compressão }\end{array}$ & $\begin{array}{c}\text { Volume } \\
\text { deslocado }\left(\mathrm{cm}^{3}\right)\end{array}$ \\
\hline 0 & 10,75 & 87,96 & 77,21 & $8,2: 1$ & 1408,97 \\
\hline 1 & 9,89 & 88,85 & 78,96 & $9: 1$ & 1423,22 \\
\hline 2 & 9,07 & 89,76 & 80,69 & $10: 1$ & 1437,8 \\
\hline 3 & 8,24 & 90,67 & 82,43 & $11: 1$ & 1452,38 \\
\hline 4 & 7,41 & 91,59 & 84,18 & $12,4: 1$ & 1467,11 \\
\hline 5 & 6,57 & 92,52 & 85,95 & $14: 1$ & 1482,01 \\
\hline 6 & 5,73 & 93,47 & 87,74 & $16,3: 1$ & 1497,23 \\
\hline 7 & 4,89 & 94,43 & 89,54 & $19,3: 1$ & 1512,6 \\
\hline 8 & 4,04 & 95,41 & 91,37 & $23,6: 1$ & 1528,3 \\
\hline 9 & 3,18 & 96,4 & 93,22 & $30,3: 1$ & 1544,16 \\
\hline 10 & 2,32 & 97,42 & 95,1 & $42,0: 1$ & 1560,5 \\
\hline
\end{tabular}




\section{6.}

\section{Ajuste de posição da engrenagem solar}

Um dos sistemas de variação da configuração do motor Kopelrot está na possibilidade de se mudar a posição da engrenagem solar. Alterando-se a posição da engrenagem solar, altera-se a posição do ponto de inflexão da curva epiciclóide cardioide, gerada pelos braços da planetária, mostrados nas Figura 2-7 e Figura 2-8. Ao girar a engrenagem solar, o ponto de inflexão muda angularmente em relação ao centro daquela.

A mudança do ponto de inflexão do volante resulta numa alteração do movimento dos pistões no ECS. Anteriormente, foram realizadas algumas simulações nas quais mostrava-se que uma variação da solar resultaria numa alteração da posição do ponto morto superior e na taxa de compressão. No entanto tal variação da taxa de compressão não foi constatada no protótipo real, quando a excentricidade era nula. Mais estudos deverão ser feitos sobre a variação da taxa de compressão.

\section{7. \\ Ciclo Atkinson / Miller}

A diferença do ciclo Atkinson/Miller em relação ao ciclo Otto está na diferença entre o curso de admissão e exaustão. No ciclo Miller o volume de admissão é menor que o volume de expansão, resultando em maior eficiência termodinâmica do motor. Essa redução da admissão nos motores alternativos é feita por meio de uma manipulação no tempo de abertura e fechamento de válvulas de admissão. Ao fechar as válvulas um pouco antes ou um pouco depois do ponto morto inferior, o motor admite menos mistura.

Com fechamento anterior, o pistão ainda não atingiu seu ponto mais baixo quando ocorre o fechamento, admitindo menos mistura que o normal. E pelo fechamento tardio, o motor admite o máximo de mistura, mas como a válvula ainda está aberta, parte da mistura escoa de volta para o coletor de admissão no início de processo de subida do pistão, e assim o volume admitido pela câmara é inferior.

No motor Kopelrot a utilização do ciclo Miller é possível por um processo similar ao fechamento tardio de válvula. Mas, ao invés de manipulação do tempo de abertura e fechamento de válvula, esse processo se faz através de um rebaixo na 
câmara de combustão, de forma que parte dos gases durante a fase de compressão escoe de volta para câmara antecessora, que está na fase de admissão. Esse rebaixo pode ser visualizado na Figura 2-14.

Assim como nos motores alternativos, o motor Kopelrot também melhora sua eficiência ao utilizar o ciclo Miller. No entanto o motor perde taxa de compressão, volume admitido e potência, mas como o motor Kopelrot possui taxa de compressão e volume deslocado variável, é possível aliar o aumento de eficiência do ciclo Miller com o aumento de taxa de compressão do sistema de excentricidade, resultando em um motor de condição de funcionamento totalmente otimizada para cada situação. No entanto, no presente protótipo, o rebaixo do ciclo Miller não pode ser variável dinamicamente assim como a taxa de compressão e ajuste da solar. Porém um dos objetivos do projeto do motor Kopelrot é a automatização para otimização desses parâmetros de funcionamento.

A variação da eficiência térmica e potência do ciclo Miller em relação ao ciclo Otto pode ser vista nas Figura 2-27 eFigura 2-28.

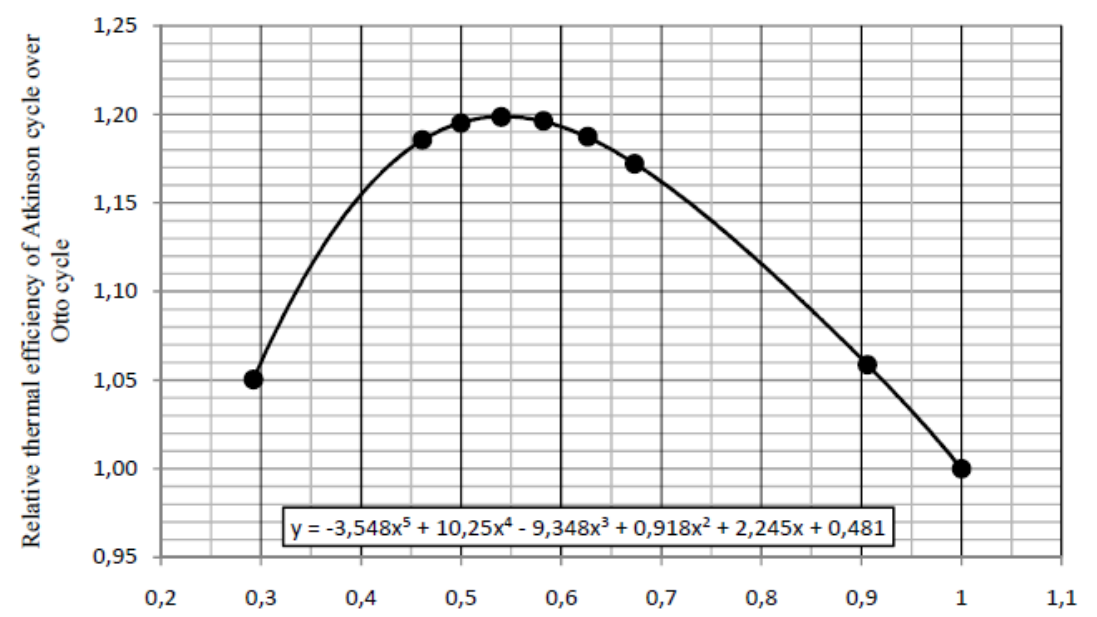

Figura 2-27 Ganho de eficiência térmica do ciclo Miller em relação ao ciclo Otto em função da compressão, de $0,3=30 \%$ de compressão a $1=100 \%$ de compressão (ciclo Otto) (Guarato et al., 2015) 


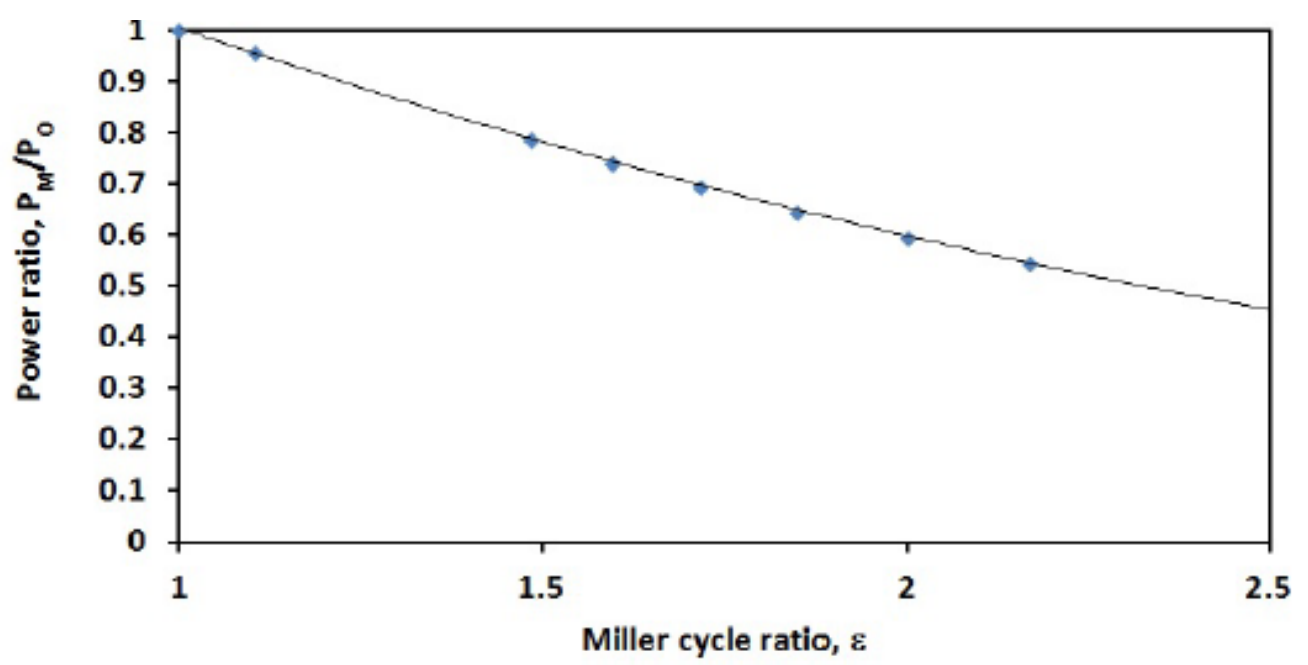

Figura 2-28 Razão de potência do ciclo Miller sobre Ciclo Otto, em relação a razão entre curso de expansão sobre curso de admissão, (Ticona et al.,2015).

\subsection{Comentários sobre o motor Kopelrot}

Como foi apresentado nesse capítulo, o motor Kopelrot possui as seguintes características principais:

- Opera com mecanismo que permite a alteração da sua taxa de compressão, de 8:1 até 42:1;

- Opera com mecanismo de ajuste da engrenagem solar, que serve para reposicionar o ponto morto superior do motor em relação à câmara do sistema de conversão de energia (sistema de referência do eixo primário);

- Possibilidade de funcionar com ciclo Otto e/ou Atkinson/Miller.

- Possibilidade de combinar o mecanismo de taxa de compressão variável com ciclo Atkinson/Miller, a fim de se obter maiores eficiências térmicas. 


\section{3 \\ Desenvolvimento do Projeto e Montagem}

\section{1. Introdução à montagem do motor}

O presente capítulo tem como objetivo apresentar o processo de revisão de projeto, ajuste e montagem do motor Kopelrot e as decisões tomadas para solucionar os diversos problemas que surgiram conforme a montagem do motor avançava.

\section{2.}

\section{Projeto do motor Kopelrot}

O motor, objeto de estudo desse trabalho, é o resultado do projeto e desenvolvimento de uma equipe formada por pesquisadores, engenheiros e alunos da PUC-Rio. Esse motor foi projetado tendo como base um protótipo anterior, do inventor Hugo Julio Kopelowicz, garantido em depósito de patente (Kopelowicz, 1988, 2012).

O projeto foi desenvolvido entre o final de 2014 e meados de 2016. A fabricação das peças foi realizada do segundo semestre de 2015 até início de 2017. E a etapa de revisão de projeto, montagem e ajustes, ocorreu durante todo o ano de 2017, pelo autor do presente trabalho.

O projeto do motor Kopelrot foi feito utilizando o software SolidWorks. Com a ajuda desse software foi possível produzir os desenhos de fabricação, simulações, vídeos, e diversas imagens do modelo, algumas das quais estão contidas no presente trabalho.

\section{3.}

Revisão de projeto, montagem, fabricação e ajustes

Todos os componentes do motor Kopelrot, peças usinadas, parafusos, arruelas, porcas, rolamentos e acessórios externos, se encontram no laboratório de 
usinagem do campus de São Marcelo da PUC-Rio, Figuras 3-1 e 3-2. Todas as etapas de revisão de projeto, correção de desenhos, alteração de projeto, montagem, ajuste, usinagem foram feitos no laboratório de usinagem de São Marcelo.

Durante todo o processo de montagem e ajuste foram notados diversos problemas, de origem na fabricação e no projeto. Várias das peças utilizadas no motor foram usinadas por empresas terceirizadas, das quais muitas apresentaram erros de fabricação. Devido aos inúmeros problemas encontrados no processo de montagem do motor, diversas peças precisaram ser ajustadas com processos de usinagem. Todos os ajustes realizados estão descritos nas tabelas 3-1 e 3-2, de forma que a descrição sobre as alterações estão organizadas da seguinte forma:

- As duas colunas à esquerda indicam qual peça foi ajustada.

- Demanda: indica que tipo de intervenção foi feito na peça.

○ Correção: correção de alguma dimensão de projeto

○ Modificação: alteração de especificação de projeto

- Peça adicional: peça não prevista no projeto

- Problema: descrição breve do que foi feito

- Origem do problema: origem da causa do problema da peça

○ Projeto: ajuste não estava previsto em projeto

○ Fabricação: fabricação não condizente com o projeto

- Experimento: itens necessários para a realização dos experimentos preliminares do motor

- Processo envolvido: máquinas de usinagem utilizadas em cada ajuste

No próximo capítulo será abordada a etapa experimental do presente trabalho, com o motor Kopelrot acionado externamente por um motor elétrico. 


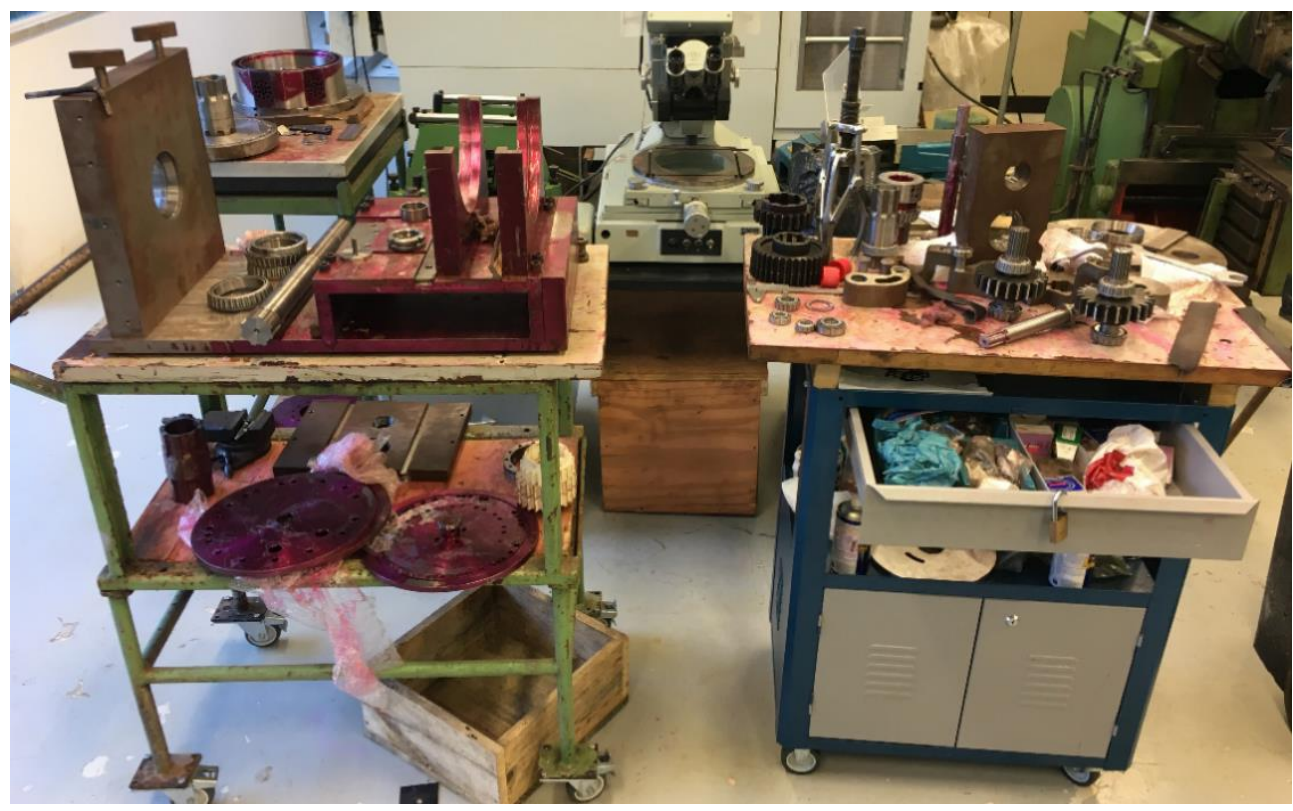

Figura 3-1 Peças no laboratório de São Marcelo (em cima da bancada do lado esquerdo se encontram as bases e mancais já montados)

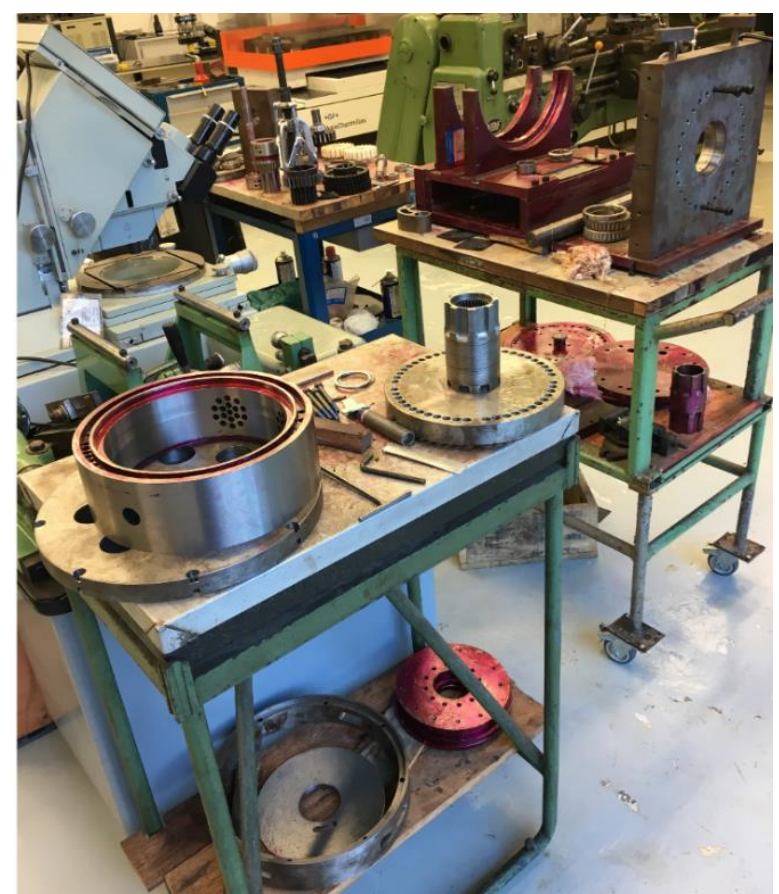

Figura 3-2 Peças no laboratório de São Marcelo da PUC-Rio 
Tabela 3-1 Lista de alterações

\begin{tabular}{|c|c|c|c|c|}
\hline Peça & Demanda & problema & $\begin{array}{l}\text { origem do } \\
\text { problema }\end{array}$ & $\begin{array}{l}\text { processo } \\
\text { envolvido }\end{array}$ \\
\hline Engrenagem solar & correção & diâmetro primitivo e passo dos dentes & fabricação & $\begin{array}{l}\text { recozimento, } \\
\text { fresa }\end{array}$ \\
\hline Engrenagem planetária & correção & $\begin{array}{l}\text { diâmetro externo superior ao diâmetro } \\
\text { nominal }\end{array}$ & fabricação & retífica \\
\hline Cilindro da planetária & modificação & $\begin{array}{c}\text { Diâmetro interno interferindo com as } \\
\text { engrenagens }\end{array}$ & projeto & fresa \\
\hline $\begin{array}{l}\text { Espaçador do eixo da } \\
\text { planetária }\end{array}$ & correção & $\begin{array}{l}\text { Diâmetro interno inferior ao diâmetro do eixo } \\
\text { da planetária }\end{array}$ & projeto & torno \\
\hline $\begin{array}{l}\text { Espaçador para } \\
\text { rolamentos do eixo da } \\
\text { planetária }\end{array}$ & $\begin{array}{c}\text { peça } \\
\text { adicional }\end{array}$ & $\begin{array}{l}\text { Folga axial excessiva na montagem dos } \\
\text { rolamentos do eixo da planetária }\end{array}$ & projeto & torno \\
\hline $\begin{array}{l}\text { Espaçador entre } \\
\text { rolamentos sobre o } \\
\text { eixo da engrenagem } \\
\text { solar }\end{array}$ & $\begin{array}{c}\text { peça } \\
\text { adicional }\end{array}$ & $\begin{array}{l}\text { Folga axial entre rolamentos sobre o eixo da } \\
\text { solar }\end{array}$ & projeto & torno \\
\hline $\begin{array}{l}\text { Bucha entre rolamento } \\
\text { e tampa intermediária }\end{array}$ & $\begin{array}{c}\text { peça } \\
\text { adicional }\end{array}$ & $\begin{array}{l}\text { Diâmetro real do ressalto para apoio do } \\
\text { rolamento do rotor interno muito inferior ao } \\
\text { diâmetro interno do rolamento }\end{array}$ & projeto & torno \\
\hline Tampa interna & modificação & $\begin{array}{l}\text { As tampas internas do lado da câmara por } \\
\text { onde passa o rotor foram projetadas e } \\
\text { fabricadas de forma defeituosa. Uma das } \\
\text { tampas do lado oposto foi modificada para } \\
\text { completar o conjunto }\end{array}$ & $\begin{array}{l}\text { projeto } \\
\text { fabricação }\end{array}$ & torno \\
\hline Cilindro da câmara & correção & $\begin{array}{l}\text { Ovalização, conicidade, usinagem com } \\
\text { ferramenta desgastada }\end{array}$ & fabricação & retífica \\
\hline Rotor externo & correção & $\begin{array}{l}\text { Ovalização, conicidade, usinagem com } \\
\text { ferramenta desgastada }\end{array}$ & fabricação & retífica \\
\hline Rotor interno & correção & $\begin{array}{l}\text { Ovalização, conicidade, usinagem com } \\
\text { ferramenta desgastada }\end{array}$ & fabricação & retífica \\
\hline Volante dianteiro & modificação & $\begin{array}{l}\text { Remoção de ressalto para fixação } \\
\text { parafusada sobre eixo de saída e adaptação } \\
\text { de uma nova fixação }\end{array}$ & projeto & torno \\
\hline $\begin{array}{l}\text { Arruela de fixação do } \\
\text { volante }\end{array}$ & $\begin{array}{c}\text { peça } \\
\text { adicional }\end{array}$ & $\begin{array}{l}\text { Arruela parafusada sobre eixo de saída para } \\
\text { fixação do volante dianteiro }\end{array}$ & projeto & torno \\
\hline $\begin{array}{l}\text { Eixo da engrenagem } \\
\text { solar }\end{array}$ & $\begin{array}{c}\text { correção e } \\
\text { modificação }\end{array}$ & $\begin{array}{l}\text { Diâmetro externo ovalado e rebaixo interno } \\
\text { para posicionamento de rolamento }\end{array}$ & fabricação & $\begin{array}{l}\text { torno e } \\
\text { retífica }\end{array}$ \\
\hline $\begin{array}{l}\text { Calço do mancal } \\
\text { intermediário }\end{array}$ & $\begin{array}{c}\text { peça } \\
\text { adicional }\end{array}$ & $\begin{array}{c}\text { A altura do mancal intermediáro era } \\
\text { insuficiente para o alinhamento dos eixos da } \\
\text { redução }\end{array}$ & projeto & $\begin{array}{l}\text { eletroerosão } \\
\text { a fio, retífica } \\
\text { e furação }\end{array}$ \\
\hline $\begin{array}{l}\text { Calço do mancal do } \\
\text { eixo inferior }\end{array}$ & $\begin{array}{c}\text { peça } \\
\text { adicional }\end{array}$ & $\begin{array}{c}\text { A altura do mancal do eixo inferior era } \\
\text { insuficiente para o alinhamento dos eixos da } \\
\text { redução }\end{array}$ & projeto & $\begin{array}{l}\text { eletroerosão } \\
\text { a fio, retífica } \\
\text { e furação }\end{array}$ \\
\hline Suporte da Câmara & Correção & $\begin{array}{c}\text { Altura excessiva do suporte da câmara para o } \\
\text { alinhamento dos rotores com os outros } \\
\text { mancais }\end{array}$ & $\begin{array}{l}\text { projeto } \\
\text { fabricação }\end{array}$ & $\begin{array}{l}\text { eletroerosão } \\
\text { a fio, retífica }\end{array}$ \\
\hline $\begin{array}{l}\text { Tampas externas e } \\
\text { intermediária }\end{array}$ & modificação & $\begin{array}{l}\text { Eliminar a interferência entre arestas das } \\
\text { tampas externas com o filete do suporte da } \\
\text { câmara }\end{array}$ & fabricação & torno \\
\hline Mancal do eixo inferior & modificação & $\begin{array}{l}\text { Rebaixo para ceder espaço para as cabeças } \\
\text { de parafusos na montagem da tampa externa }\end{array}$ & projeto & torno \\
\hline Mancal do volante & modificação & $\begin{array}{c}\text { Ajuste da distância entre mancal do volante e } \\
\text { mancal intermediário }\end{array}$ & projeto & furadeira \\
\hline Base do motor & modificação & $\begin{array}{c}\text { Ajuste da distância entre mancal do volante e } \\
\text { mancal intermediário }\end{array}$ & projeto & furadeira \\
\hline Rotor Externo & modificação & $\begin{array}{l}\text { Rebaixo para eliminar a interferência entre a } \\
\text { gaiola do rolamento e o rotor }\end{array}$ & projeto & torno \\
\hline Tampa interna & modificação & $\begin{array}{l}\text { Furação e rosca para fixação do mancal- } \\
\text { tampa }\end{array}$ & fabricação & furadeira \\
\hline
\end{tabular}


Tabela 3-2 Lista de alterações (continuação)

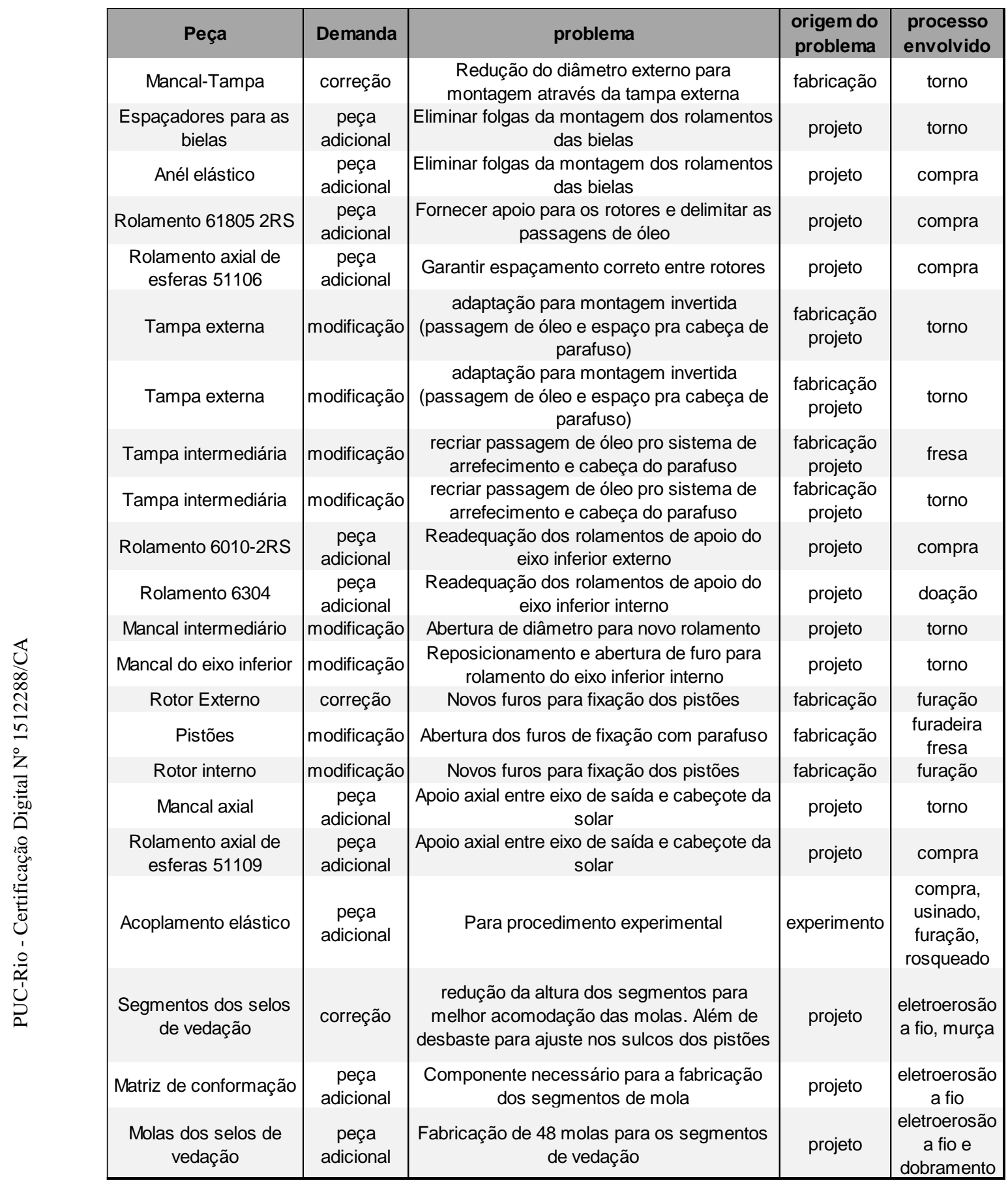




\section{Experimento e Resultados}

Os testes foram realizados no Laboratório de Engenharia Veicular da PUCRio. Devido às dificuldades técnicas, e complexidades do projeto, alguns sistemas do motor ficaram ausentes dos testes preliminares, como a vedação entre rotores, sistema de lubrificação e de arrefecimento. Para mitigar a falta desses elementos cruciais, os rolamentos e engrenagens do motor foram lubrificados com graxa, enquanto que a câmara e os deslocadores foram lubrificados com óleo lubrificante de motor automotivo.

A avaliação experimental teve como objetivos medir o torque e a potência (do acionamento externo), vazão volumétrica, rotação (ou velocidade angular) e pressão máxima da compressão do motor, ao ser acionado externamente por um motor elétrico.

\section{1.}

\section{Aparato experimental}

Foi construída uma bancada para suportar o protótipo, como pode ser visto na Figura 4-1.

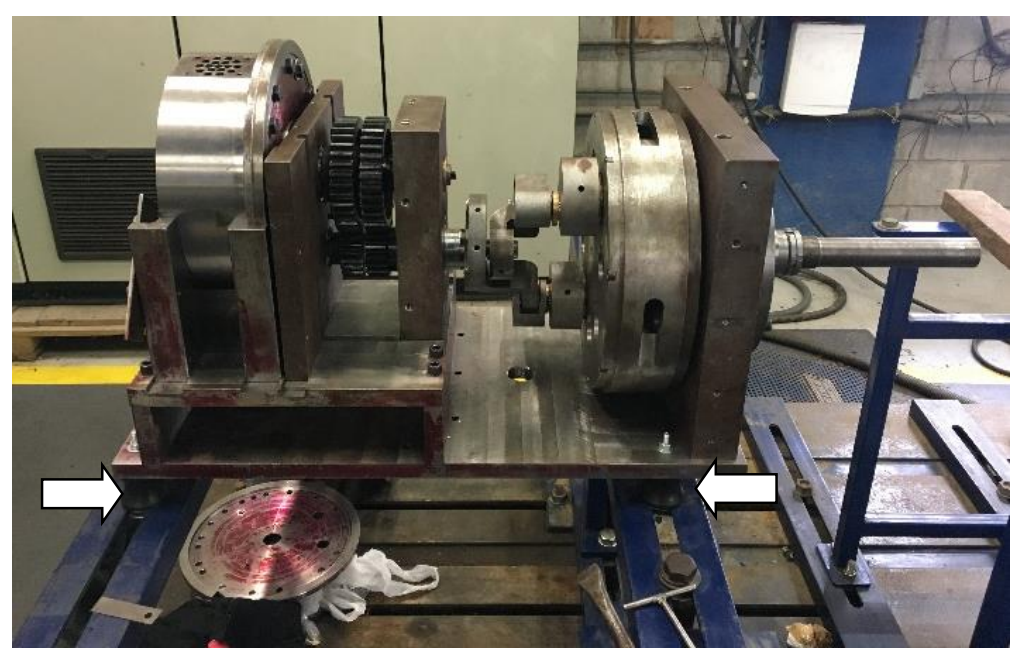

Figura 4-1 Motor montado sobre os coxins (indicado com setas) e bases 


\subsection{1.}

\section{Acionamento externo}

Para o acionamento do motor Kopelrot, foi utilizado um motor elétrico de 3,7 $\mathrm{kW}$ de potência nominal, ligado a um inversor de frequência Weg CFW08, no qual era possível definir a rotação desejada para o funcionamento, e também medir a corrente e tensão fornecida ao motor elétrico, para assim obter a potência útil de acionamento do motor, Figura 4-2. No entanto, devido à configuração do inversor de frequência, que não possuía saída analógica, não foi possível aquisitar os valores de corrente e tensão do inversor, e assim foram obtidos visualmente pelo display LED do próprio inversor de frequência.

Com o intuito de se evitar interferência na instrumentação de aquisição dos dados, o motor elétrico foi isolado eletricamente do restante da bancada, apoiandoo sobre um suporte de material não condutor. $\mathrm{O}$ isolamento elétrico também foi feito entre o eixo do motor elétrico e do motor Kopelrot, através dos componentes de borracha do acoplamento elástico, Figura 4-3.

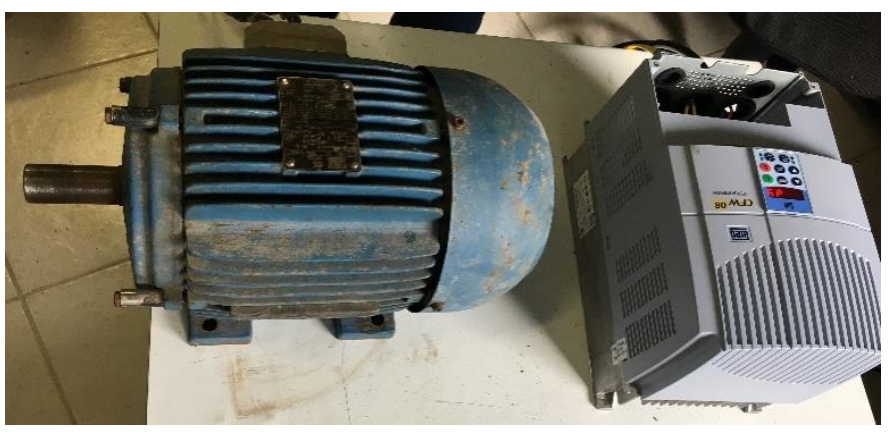

Figura 4-2 Motor elétrico e Inversor de Frequência

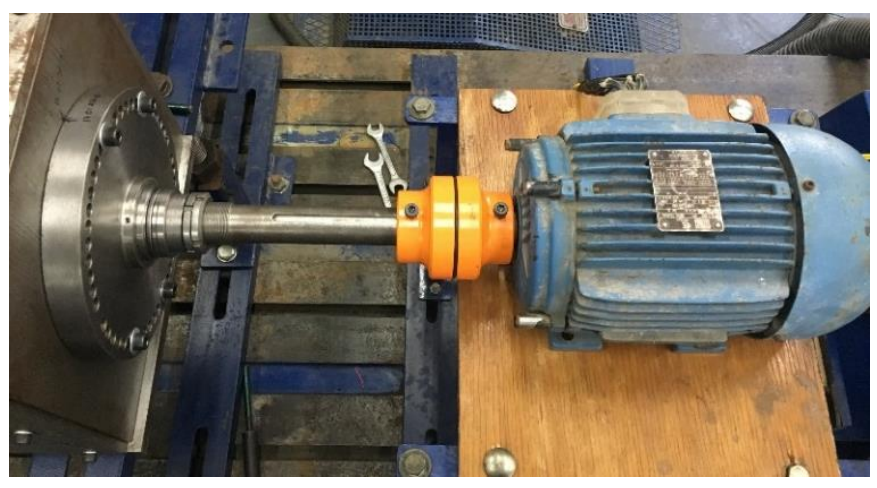

Figura 4-3 Motor elétrico acoplado ao eixo do motor Kopelrot 


\subsection{2. \\ Instrumentação}

Para instrumentar e medir os dados dos ensaios experimentais, foi necessária a utilização de alguns sensores, amplificador e placa de aquisição de dados.

Para a medição da vazão volumétrica, de admissão, foi utilizado um medidor de vazão de fluxo laminar da Meriam, modelo 50MW20, que utiliza um sensor de pressão diferencial, um sensor de pressão absoluta e um sensor de temperatura Pt100. Esse medidor de vazão foi escolhido em função da sua faixa de medição.

Para conectar o medidor de vazão ao motor Kopelrot, foi necessário fabricar um bocal de admissão, parafusado ao cilindro da câmara, de onde foi preso uma mangueira até o pulse-damping, conectado ao medidor de vazão.

Para a medição da compressão máxima, no ponto morto superior da câmara, foi utilizado um sensor de pressão piezoelétrico Kistler, montado próximo a vela de ignição do motor. Esse sensor envia o sinal elétrico para um amplificador da Kistler $^{\mathrm{TM}}$, type 5064. O sinal desse amplificador era enviado à placa de aquisição de dados, para então ser enviado ao computador para o armazenamento dos dados. Um osciloscópio também foi utilizado para fazer a leitura do sinal da saída do amplificador. O sensor de pressão e o amplificador podem ser vistos na Figura 4-4.

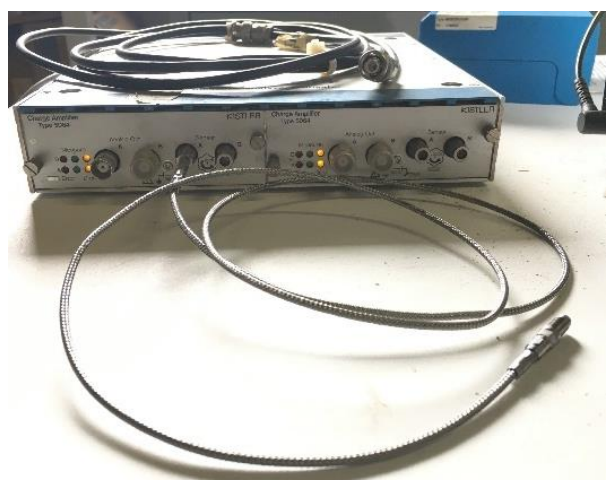

Figura 4-4 Sensor de pressão piezoelétrico e amplificador Kistler type 5064

Para a aquisição dos dados foi utilizado um dispositivo da National Instruments ${ }^{\mathrm{TM}}$, modelo NI USB-6363, para converter o sinal analógico dos sensores, e enviar o sinal digital para o computador. Os sinais, processados em software LabVIEW ${ }^{\mathrm{TM}}$, eram mostrados em uma interface própria, que serve para gerir o início e o fim da aquisição de dados, e visualização dos valores medidos: pressão diferencial, pressão absoluta, temperatura e a pressão do piezoelétrico. Também foi possível definir o intervalo de aquisição dos dados, que para todos os 
testes foi definido como intervalo de $0,1 \mathrm{~s}$. Um circuito elétrico também foi confeccionado para a alimentação dos sensores do medidor de vazão. A placa de aquisição de dados, o circuito e a interface especial do LabVIEW podem ser vistos nas Figura 4-5, Figura 4-6 e Figura 4-7.

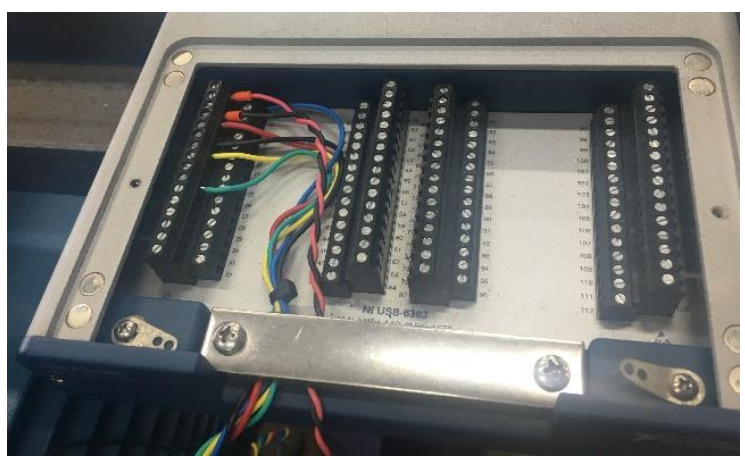

Figura 4-5 Placa de aquisição de dados da National NI USB-6363

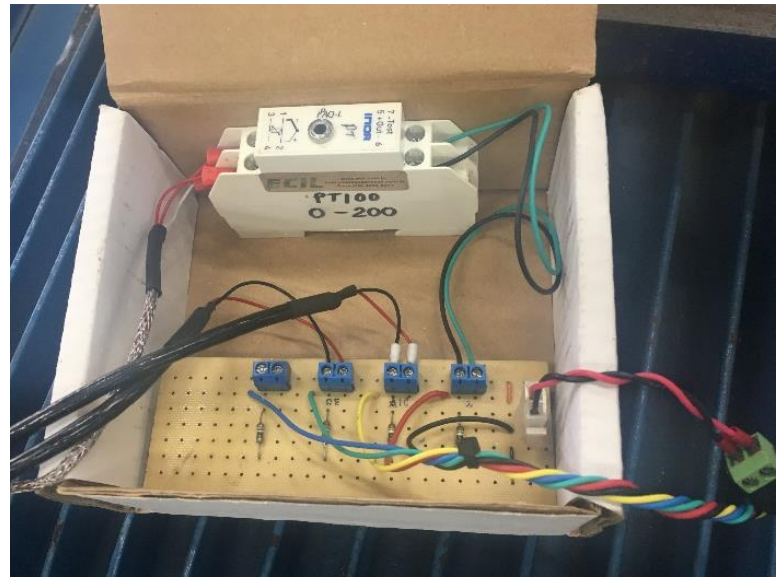

Figura 4-6 Circuito de alimentação dos sensores do medidor de vazão

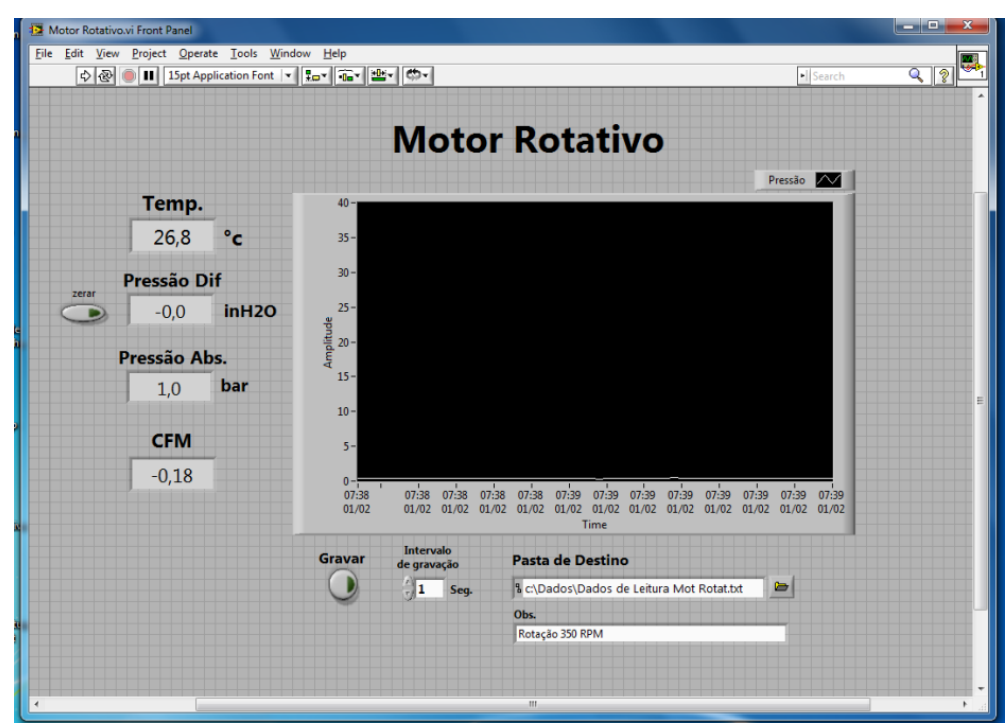

Figura 4-7 Interface do LabVIEW (desenvolvido pelo Laboratório de Engenharia Veicular) 


\section{2.}

\section{Planejamento}

Os objetivos iniciais da avaliação experimental eram a medição da vazão de ar admitido pelo motor, a compressão máxima na câmara e a potência mecânica fornecida ao motor. No entanto, após efetuados alguns testes preliminares, constatou-se a ausência de compressão na câmara.

Para a obtenção da potência mecânica, foram utilizados os dados de tensão e corrente elétrica do motor elétrico.

Antes dos testes efetuados, o motor foi acionado com uma velocidade de 200 rpm, quando foi observada uma vibração que poderia ser prejudicial ao funcionamento do motor e na execução dos testes. Os testes foram realizados inicialmente para a excentricidade zero do motor, iniciando-os a baixas rotações e progredindo aos poucos.

\subsection{1.}

\section{Dos ensaios}

Os testes foram efetuados com velocidade angular de 200, 250, 300, 350 e $400 \mathrm{rpm}$. Os dados de vazão volumétrica eram adquiridos em formato .txt, enquanto que os valores de corrente e tensão, da saída do inversor de frequência, eram obtidos de forma visual e manual em todos os testes. Os testes foram efetuados de forma sequencial. O regime permanente era alcançado após 10 minutos de cada teste.

\subsection{2.}

\section{Redução de dados}

Os dados referentes ao medidor de vazão eram fornecidos por três sensores, o de pressão diferencial, de pressão absoluta e temperatura. A pressão diferencial foi utilizada para se obter a vazão volumétrica não corrigida. Enquanto que a pressão absoluta e temperatura são utilizadas para se obter a vazão volumétrica padrão corrigida em pés cúbicos por minuto (CFM):

$$
\left(B \times D P+C \times D P^{2}\right) \times\left(\frac{\mu_{s t d}}{\mu_{f}}\right) \times\left(\frac{P_{f}}{P_{s t d}}\right) \times\left(\frac{T_{s t d}}{T_{f}}\right)=C F M
$$


sendo $D P$ a pressão diferencial em polegadas de coluna d'água inH2O, $B$ e $C$ constantes próprias do medidor de vazão, $P_{f}$ a pressão absoluta medida em polegadas de mercúrio inHg, $P_{s t d}$ a pressão padrão de 29,92 inHg.

Já a parcela de correção da viscosidade e temperatura pode ser obtida da seguinte forma:

$$
\left(\frac{\mu_{s t d}}{\mu_{f}}\right) \times\left(\frac{T_{s t d}}{T_{f}}\right)=\frac{529,67}{459,67+{ }^{\circ} \mathrm{F}} \times \frac{181,87}{\mu_{\text {air }}}
$$

onde ${ }^{\circ} \mathrm{F}$ é a temperatura do Pt100 em graus Fahrenheit, e $\mu_{\text {air }}$ a viscosidade do ar, obtida da seguinte forma:

$$
\mu_{\text {air }}=\left(\frac{14,58\left(\frac{459,67+{ }^{\circ} \mathrm{F}}{1,8}\right)^{\frac{3}{2}}}{110,4+\frac{459,67++^{\circ} \mathrm{F}}{1,8}}\right)
$$

onde ${ }^{\circ} \mathrm{F}$ é a temperatura em Fahrenheit, medida no Pt100.

As equações 5-1, 5-2 e 5-3 estão indicadas no manual do medidor de vazão do fabricante.

A vazão volumétrica em pés cúbicos por minuto foi inserida no aplicativo Excel, onde era convertida para $\mathrm{m}^{3} / \mathrm{h}$, para então ser relacionada à vazão teórica de admissão, e assim obter-se a eficiência volumétrica do motor. A densidade do estado do ar dentro do motor foi considerada idêntica à densidade de ar na admissão.

$$
\eta_{\text {vol }}=\frac{Q_{\text {medido }}}{Q_{\text {teórico }}} \times 100
$$

onde $\eta_{v o l}$ é a eficiência volumétrica, $Q_{\text {medido }}$ a vazão adquirida pelo medidor de vazão e $Q_{\text {teórico }}$ a vazão teórica, obtida a partir do volume deslocado por câmara e velocidade angular. Da seguinte forma:

$$
Q_{\text {teórico }}=V_{d} \times 2 \times \omega \times 60
$$

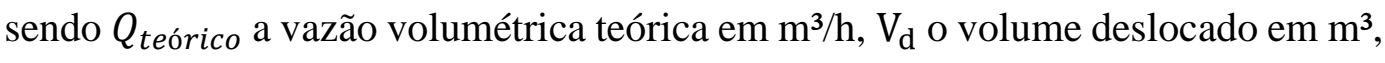
nesse caso $4,719 \times 10^{-4} \mathrm{~m}^{3}$ para excentricidade zero, $\omega$ a velocidade angular do eixo de saída em rpm. A constante " 2 " da equação (5-5) significa que a cada rotação do eixo de saída, duas câmaras admitem ar pela admissão do motor. E a costante "60" é fator de conversão de rpm para rph. 
O torque e potência no eixo de saída do motor Kopelrot eram obtidos a partir da corrente elétrica e tensão fornecida ao motor elétrico trifásico, considerando o devido rendimento do motor elétrico e seu fator de potência.

$$
P_{u}=\sqrt{3} \times U \times I \times \cos \theta \times \eta \%
$$

onde $P_{u}$ é a potência útil no eixo do motor elétrico em Watts, $U$ é a tensão em Volt, I a corrente elétrica em Ampere, $\cos \theta$ o fator de potência igual a 0,88 e $\eta \%$ o rendimento de $84,5 \%$. Com a potência útil $P_{u}$ obtem-se o torque para uma determinada velocidade angular:

$$
\tau=P_{u} \times \frac{60}{\omega}
$$

Onde $\tau$ é torque em $\mathrm{Nm}$, e $\omega$ rotação em rpm.

\section{3.}

\section{Resultados}

A seguir estão mostradas as figuras com os dados experimentais obtidos nos testes.

\subsection{1.}

\section{Torque e Potência}

Na Figura 4-8 podemos observar que a potência e torque de acionamento aumentam com a rotação.

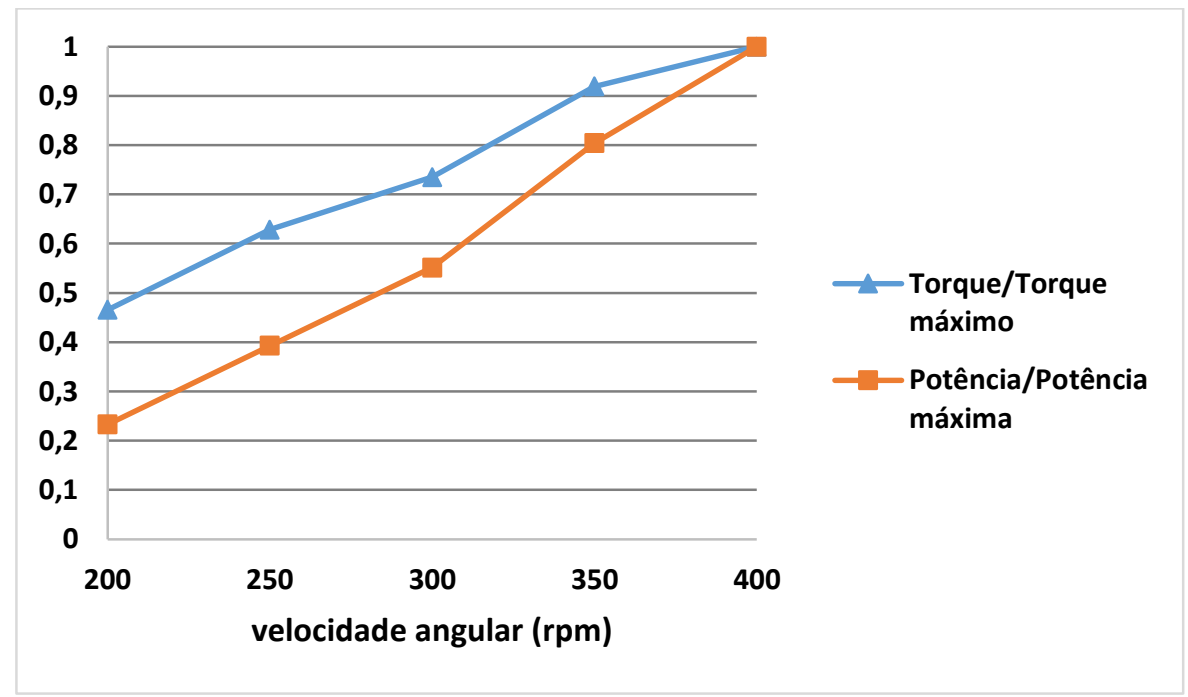

Figura 4-8 Potência / Potência máxima (Pu/Pu max) e Torque / Torque máximo ( $\tau / \tau$ max) em função da velocidade angular após 600 s de início dos testes 


\subsection{2.}

\section{Eficiências Volumétricas}

As eficiências volumétricas encontradas para as faixas de velocidade utilizadas mantearam-se dentro de uma faixa de $39 \%$ a $44 \%$. Na Figura $4-9$ podese observar as eficiências no regime permanente e compara-las com as eficiências volumétricas após um minuto de teste transcorrido. A redução da eficiência volumétrica com o tempo pode ser explicada pelo aquecimento das paredes da câmara e dos deslocadores. Com o aquecimento reduz-se a quantidade de ar admitida. A variação na condição e quantidade do óleo lubrificante também pode alterar a eficiência volumétrica. Nota-se baixas variações de eficiências volumétricas para as velocidades angulares utilizadas.

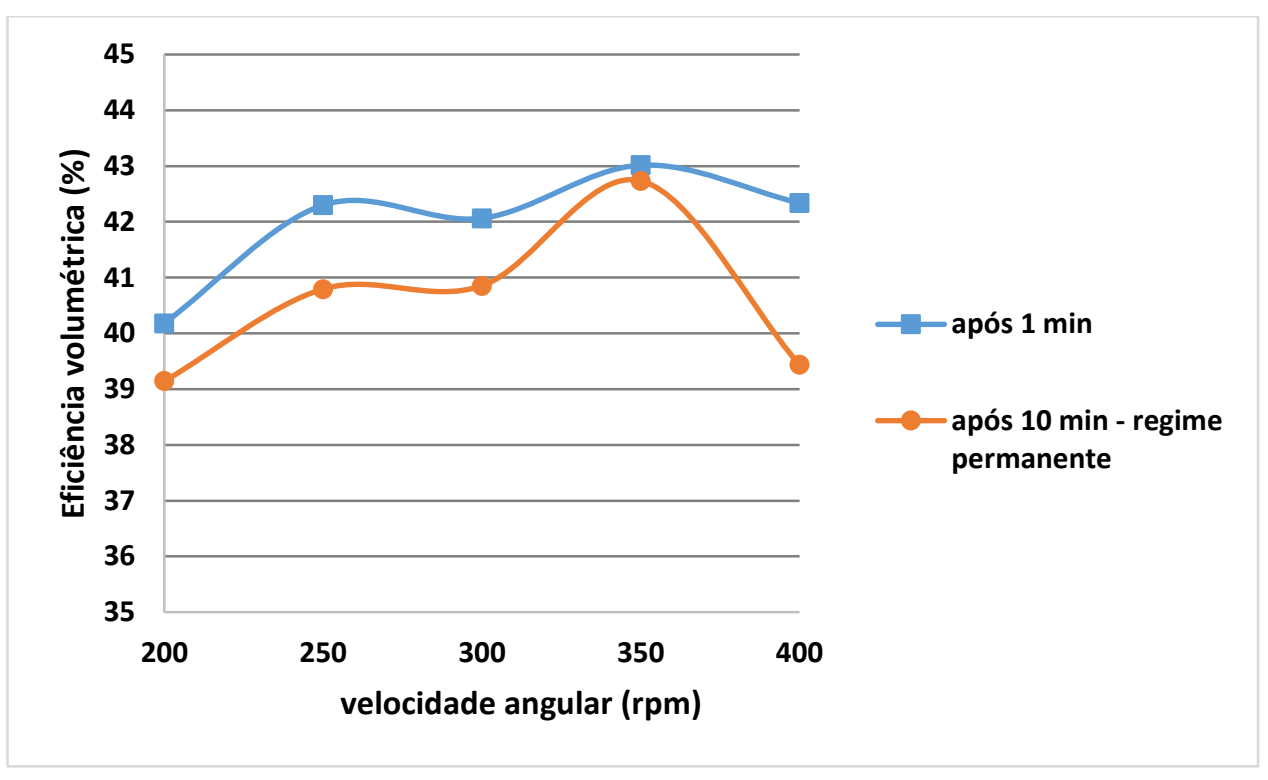

Figura 4-9 Eficiências volumétricas

\section{4.}

\section{Imprevistos experimentais}

Durante os testes surgiram problemas que prejudicaram a obtenção de mais dados. Infelizmente não se obteve nenhuma medição da compressão de ar dentro da câmara do motor Kopelrot em nenhuma rotação entre 200 rpm e 400 rpm, o que pode ser explicado pela sensibilidade do sensor piezoelétrico, de 200 bar de limite de leitura, além do fato do motor não possuir vedação entre rotores, o que reduz sua capacidade de compressão no ponto morto superior. 
Outro problema encontrado foi a vibração do motor Kopelrot, que crescia conforme incrementava-se a velocidade angular do motor elétrico a cada novo teste. Essa vibração resultou em um visível desalinhamento entre o eixo de saída do Kopelrot e o eixo do motor elétrico. Os coxins também apresentaram deflexões significativas e visiveis.

Após a realização dos testes foi verificado que alguns parafusos de fixação dos componentes mecânicos haviam se soltado. Além disso, o eixo da solar, que conecta a engrenagem solar ao cabeçote da solar, e que apoia o eixo de saída, deslocou-se axialmente para o interior do motor Kopelrot, fazendo com que a engrenagem solar atritasse sobre o volante do sistema planetária.

Além das vibrações mecânicas, a corrente elétrica fornecida ao motor elétrico atingiu valores superiores ao limite nominal do motor elétrico a $400 \mathrm{rpm}$. O limite indicado pelo fabricante do motor elétrico é de 13,1 A, enquanto que o inversor de frequência forneceu valores de até 15 A para o motor a 400 rpm.

Todos os problemas citados foram relevantes na decisão de encerrar os testes, devido aos riscos de danos ao motor Kopelrot, aos equipamentos de aquisição de dados e ao Laboratório de Engenharia Veícular. O prosseguimento do testes seria incerto, pois a corrente elétrica fornecida ao motor elétrico chegaria a um máximo a partir do qual não seria possível aumentar a rotação do motor. 


\section{5 \\ Conclusões e propostas}

Nessa seção serão apresentados os comentários finais sobre o presente trabalho, incluindo conclusões e propostas para futuros trabalhos. Foram propostas modificações que podem ser feitas no presente protótipo, mudanças de projeto para os próximos protótipos, e elementos que podem ser pesquisados nos próximos trabalhos.

\section{1.}

\section{Conclusões sobre o que foi feito}

Após a construção, montagem e testes preliminares é preciso salientar pontos importantes a respeito do motor. O projeto e o planejamento são cruciais para o sucesso do motor, por se tratar de uma máquina complexa. No entanto, por ser um projeto acadêmico, a experiência de profissionais da indústria e comércio faz toda a diferença para tomar as melhores decisões a respeito da disponibilidade, padronização e o preço de peças no mercado. A falta de uma pesquisa de disponibilidade de peças do mercado resulta no encarecimento desnecessário do projeto. Pequenas diferenças, como passo de parafuso, e rolamentos, podem quadruplicar os gastos em componentes mecânicos. Além disso, a pesquisa de componentes mecânicos, eventualmente disponíveis no mercado, pode baratear a fabricação do motor.

O projeto da montagem mecânica e fabricação é crítico nesse motor rotativo, devido ao seu funcionamento incomum e inovador. Erros triviais de projeto podem comprometer seriamente o resultado final. É necessário simplificar o projeto, reduzir o número de peças, aprimorar a precisão e ajuste de montagem.

Sobre os experimentos, a vibração mecânica foi o maior dos problemas. O sistema de vedação, lubrificação e arrefecimento poderão ser providenciados, mas a vibração mecânica representa o maior desafio para o motor no atual estágio de projeto. Pois mesmo que todos os sistemas estejam funcionando, a vibração torna o 
motor instável, colocando em risco não só motor, mas todos os equipamentos periféricos utilizados.

Os próximos aprimoramentos do motor deverão lidar com as forças inerciais do DVDM e do ECS. Deve-se encontrar uma forma de garantir o balanceamento do motor, e assim mitigar as vibrações indesejadas.

Para solucionar o problema de vedação dos pistões e rotores do ECS, é interessante que se construam modelos simplificados para o teste de diferentes configurações de vedação.

\section{2.}

\section{Propostas de alteração para o presente protótipo}

\subsection{1.}

\section{Sistema de vedação}

Um dos principais componentes para o pleno funcionamento do motor, os selos de vedação entre rotores, não foi providenciado a tempo de realizar os testes experimentais. A solução para esses problemas já foi discutida por membros do grupo do projeto do motor para ser implementada futuramente. Mas tendo em vista da potencialidade de um sistema de vedação patenteável para esse motor, seus detalhes não estarão aqui abordados.

\subsection{2.}

\section{Suporte e rolamento dos rotores}

Durante a montagem do protótipo foi notada uma disparidade entre os apoios dos rotores da câmara de combustão. Enquanto que o rotor externo é apoiado sobre dois rolamentos robustos, o rotor interno é apoiado por rolamentos menores. Foi discutido que seria aconselhável a mudança do projeto antes dos testes de combustão serem realizados a fim de garantir um melhor apoio para o rotor interno resistir aos altos esforços mecânicos durante a combustão. A ideia proposta foi a fabricação de uma peça para prolongar o rotor interno, projetando-o para fora da câmara, na qual poderá ser montado rolamentos mais robustos para apoio do rotor. 


\subsection{3.}

\section{Suporte para rolamento axial do eixo de saída}

Outro problema notado durante a montagem do motor foi a ausência de algum componente eficaz para garantir a montagem axial do conjunto do eixo de saída, sistema da solar e sistema planetário. Originalmente foi proposto porca e contra porca montadas sobre o eixo de saída, aplicando força sobre o volante do sistema da solar, para garantir o travamento axial do sistema. O problema é que, nessa configuração, as porcas atritavam diretamente sobre o volante da solar, tendo em vista que as porcas estão montadas sobre o eixo de saída. Para solucionar esse problema foi proposto um rolamento axial, situado entre as porcas e o volante, para que as forças axiais não causassem um travamento na rotação do motor. De fato, esse rolamento e os seus mancais de apoio foram mostrados no capítulo sobre a montagem. No entanto, eles deverão ser aprimorados para os testes em maiores velocidades angulares.

Para os testes com maiores velocidades angulares, esses mancais de apoio serão modificados e ampliados para receber um conjunto de vedação e uma entrada de óleo. A entrada de óleo servirá para lubrificar não só o rolamento axial mas também os dois rolamentos entre o eixo de saída e o eixo da solar. O óleo fluirá desde a entrada, do lado exterior do motor, até a parte interna do volante do sistema planetária, passando pelos dois rolamentos. Esse fluxo adicional de óleo servirá não apenas para lubrificar os rolamentos mas também para aumentar o efeito lubrificante sobre as engrenagens planetárias e solar.

\section{3.}

\section{Propostas para os próximos protótipos}

Foram observados alguns problemas de projeto durante a montagem do motor que deverão ser evitados em futuros protótipos. Além das alterações já indicadas para serem feitas ainda no protótipo atual, existem outros detalhes que deverão ser levados em conta e são discutidos a seguir 


\subsection{1. Dos rolamentos utilizados}

Para o atual protótipo foram propostos inúmeros rolamentos cônicos, em aplicações onde não existem altos níveis de cargas axiais que justifiquem a utilização de tais rolamentos. É claro que não se pode desprezar a possibilidade do surgimento de cargas axiais indesejadas, mas sua ocorrência seria em amplitudes baixas, que poderia ser facilmente resistida com rolamentos de esferas ou uma combinação de agulhas com esferas.

O ideal seria uma combinação de rolamentos de agulha e de roletes, por resistirem a maiores forças radiais. Os rolamentos de esferas seriam úteis para evitar quaisquer cargas axiais indesejadas. E também seria interessante uma possível utilização de rolamentos auto compensadores entre as bielas e os braços de transição dos eixos inferiores da redução, para compensar quaisquer desalinhamentos no sistema de acionamento mecânico.

\subsection{2. \\ Dos ajustes de montagem}

Em diversos pontos da montagem espaçadores e buchas tiveram de ser produzidos, a fim de proporcionar o correto posicionamento dos componentes do motor. Em outras partes o projeto precisou ser modificado, substituindo-se parafusos e pinos ajustáveis por anéis elásticos para restringir o movimento axial de peças e rolamentos.

Para o próximo protótipo deverá ser pensado como o motor será montado de forma que todas as peças possuam apenas uma posição fixa de montagem, sem flexibilização da posição dos componentes.

\subsection{3.}

\section{Dos mancais suportes e bases}

Foi percebido que, quanto maior o número de peças, encaixes e montagens parafusadas, mais trabalhosa se torna a montagem. O projeto inicial foi pensado de forma a simplificar os processos de fabricação dos componentes, aumentando o número de peças mas simplificando seus formatos. No entanto, essas simplificações resultaram no aumento do número de elementos de fixação, seus respectivos furos, 
e retificação de interfaces de montagem. Sendo que todas essas adições, de peças e elementos de fixação, resultaram no surgimento de fontes de erros de ajuste e desalinhamento, entre os diversos mancais que possuíam rolamentos alojados. Tais erros tornaram necessários usinagens adicionais, além da utilização de calços extras para alinhamento das peças.

Nos próximos protótipos é extremamente aconselhável a união de várias peças redundantes em apenas uma (como as tampas laterais do ECS ou os mancais e suportes), caso existam componentes com múltiplos apoios, como os rotores. $\mathrm{O}$ par de rotores apoia-se em quatro pontos, os dois mancais da redução, e os dois apoios da câmara. O desalinhamento entre esses apoios foi inevitável durante a montagem devido a erros de projeto e fabricação das peças, além da influência das diversas uniões de peças apenas com parafusos, e os diversos calços e espaçadores. A consequência desse desalinhamento influencia diretamente sobre a posição dos rotores e pistões no interior da câmara, o que prejudica o correto funcionamento do motor. Dessa forma, seria aconselhável que os diversos apoios do par de rotores pertencessem a um menor número de peças possível, e que essas peças sejam montadas auxiliadas por pinos guias. Dessa forma reduzir-se-ia a chance de desalinhamento relativo entre apoios devido à montagem, sendo seu alinhamento dependente apenas do processo de fabricação da peça.

\subsection{4. \\ Da Posição da ignição e janelas de admissão e exaustão}

Para os próximos protótipos é preciso repensar a posição da ignição. É necessário que o rebaixo da vela de ignição não sofra acúmulo de óleo no desligamento do motor, caso esteja na parte inferior da câmara.

\section{4 .}

\section{Propostas para os próximos trabalhos}

Para os próximos trabalhos existem diversos aspectos do funcionamento do motor que poderão ser estudados e aprimorados. Dentre eles podem-se listar os seguintes pontos:

- Testes de acionamento a altas rotações, utilizando sistema de vedação completo. 
- Testes iniciais do sistema de óleo de arrefecimento e sua capacidade de funcionamento.

- Estudo do efeito da variação dinâmica da taxa de compressão no funcionamento do motor (utilizando sistema de excentricidade).

- Estudo do efeito da variação da taxa de compressão com a alteração do ponto morto superior, utilizando o ajuste da engrenagem solar.

- Estudo do efeito da posição do rebaixo do ciclo Miller no funcionamento do motor.

- Sistema de vedação de gás e óleo, e sistema de recirculação de gás de "blow-by gas", vazamentos e emissão de gases da combustão.

- Sistema de injeção de óleo para lubrificação do interior da câmara independente do sistema de admissão.

- Sistema de arrefecimento, dilatação e gradiente de temperatura e sua influência no formato da câmara e funcionamento do motor

- Estudo de balanceamento das peças móveis, para mitigação da vibração mecânica do motor

\section{5.}

\section{Próximos passos}

A prioridade atual do projeto é solucionar os problemas de vibração e vazamentos encontrados nos testes preliminares. Após a resolução desses problemas mais testes poderão ser efetuados. 


\section{6}

\section{Referências bibliográficas}

AL-HAWAJ, O. M. Geometrical analysis of a quadrilateral rotary piston engine. Mechanism and Machine Theory, n. 93, p. 112-126, Novembro 2015.

ATKINSON, J. Gas-Engine. US Patent No. 367,496 (A), 13 Outubro 1886, 2 Agosto 1887.

AUTOCAR. AutoCar, 15 abr. 2010. Disponivel em: <http://www.autocar.co.uk/car-news/motoring/mazda-kills-rx-8-sportscoupe >. Acesso em: 26 jun. 2016.

BARRETO, A. R. Análise Teórica e Simulação Numérica de um Compressor Rotativo. [S.I.]. 2003.

BARRETO, A. R.; KOPELOWICZ, H. J.; PARISE, J. A. R. Simulation of An Innovative Rotary Compressor With Variable Speed Displacers. In. Seventh International Compressor Engineering Conference at Purdue. [S.I.]: Purdue e-Pubs. 12-15 Julho USA, 2004. p. C128, p 1-8.

BECK, F. Rotary Explosion Motor. US Patent No. 977,260 A, 7 Dezembro 1909, 29 Novembro 1910.

BECKWITH, J. AutoCar, 6 abr. 2016. Disponivel em: $<$ http://www.autocar.co.uk/car-news/new-cars/mazda-readies-newturbocharged-rotary-engine>. Acesso em: 26 jun. 2016.

BULLINGTON, F. A. Rotary internal-combustion engine. US Patent No. 1,482,627 A, 17 Junho 1918, 5 Fevereiro 1924.

COOLEY, F. J. Rotary fluid-motor. US Patent No. 724,665, 31 Janeiro 1903, 7 Abril 1903.

DENG, $H$. et al. A twin-rotor piston engine with annular connecting chambers. J Mechanical Engineering science, n. 227(5), p. 1080-1089, 2012.

DEWANDRE, A. Improved Rotary Explosion Motor. United Kingdom Patent 191028511-A, 7 Dezembro 1910, 19 Outubro 1911. 
FARRELL, M. Oscilating Piston Engine. US Patent No. 5,222,463 A, 23 Julho 1992, 29 Junho 1993.

FLIGHT. Flight Engines at Paris Show. Flight, p. 724, 13 November 1909. GEIGER, J. Rotary piston internal combustion engines. 3036560, 30 Dezembro 1960, 29 Maio 1962.

GUARATO, A. Z.; TICONA, E. M.; BRAGA, S. L. Application of Atkinson Miller cycle on a rotary internal combustion engine In. $23 \mathrm{rd} A B C M$ International Congress of Mechanical Engineering. Rio de Janeiro, Brasil: ABCM. 2015.

GUARATO, A. Z.; TICONA, E. M.; BRAGA, S. L. Development of a flexfuel rotary engine with variable compression ratio In. 25th SAE Brasil International Congres and Display. São Paulo, Brasil: SAE technical paper series. 2016. p. № Paper: 2016-36-0218.

HEYWOOD, J. B. Internal Combustion Engine Fundamentals. 1‥ ed. New York: McGraw-Hill, 1988.

JIMÉNEZ, R. D. Simulação de um novo Motor a Combustão Interna Rotativo com Ignição por Centelha. Dissertação de Mestrado, Departamento de Engenharia Mecânica, Pontifícia Universidade Católica do Rio de Janeiro. Rio de Janeiro. 2008.

KALPAKJIAN, S.; SCHMID, S. R. Manufacturing, Engineering and Technology. 6th. ed. Upper Saddle River, New Jersey: Prentice Hall, 2009. KARIM, G. A.; BADE SHRESTHA, O. M. The Performance of a Variable Geometry Toroidal Engine. Departament of Mechanical and Manufacturing Engineering University of Calgary. Calgary, Canada, p. 46. 2000.

KAUERTZ, E. Rotary Radial-Piston Machine. US Patent No. 3,144,007 A, 28 jUNHO 1961, 11 Abril 1964.

KOPELOWICZ, H. J. System for construction of compressors and rotary engine, with volumetric displacement and compression rate dynamically variable . US Patent No. 0,195,782 A1, 4 Outubro 2010, 2 Agosto 2012.

KOPELOWICZ, H. J.; JIMÉNEZ, R. D.; PARISE, J. A. R. Desenvolvimento de um motor a combustão interna rotativo com deslocadores de velocidade angular variável e mecanismo inovador. [S.I.], p. 15. 2009. 
KRAMER, A. E. The New York Times, 13 dez. 2010. Disponivel em: <http://www.nytimes.com/2010/12/14/business/global/14hybrid14.html?_r= 2\&hpw>. Acesso em: 26 jul. 2016.

LIQUIDPISTON. WordPress., 2016. Disponivel em: <http://liquidpiston.com/>. Acesso em: 10 out. 2016.

MELVIN, R. T. Rotary Internal Combustion Engine. US Patent No. 3,356,079 A, 10 Fevereiro 1964, 5 Dezembro 1967.

MORGADO, R. G. Internal Combustion Engine and method. US Patent No. 6,739,307 B2, 26 Março 2002, 25 Maio 2004.

NORBYE, J. P. Rivals to the Wankel: Roundup of Rotary engines. Popular Science, p. 80-85, Janeiro 1967.

OEHLMANN., E. Rotary Engine. US Patent No. 309,734 A, 24 Maio 1884, 23 Dezembro 1884.

PEKAU, R. R. Variable geometry toroidal engine. US Patent No. 6,546,908 B1, 20 Novembro 1997, 15 Abril 2003.

SAINT-HILAIRE. Quasiturbine Technologies. Disponivel em: $<$ http://quasiturbine.promci.qc.ca/ERelationAboutUs.htm>. Acesso em: 13 jul. 2016.

SAINT-HILAIRE, G.; SAINT-HILAIRE, R.; SAINT-HILAIRE, Y. Quasiturbine: Low RPM high torque pressure driven turbine for efficiency power modulation In. ASME Expo Turbo 2007: Power for land sea and air, May 14-17. Montreal, Canada: ASME. 2007. p. 10.

SAKITA, M. Rotary piston engine. US Patent No. 6,446,595 B1, 3 Julho 2001, 10 Setembro 2002.

SANCHEZ, A.; BARADAT, C. Rotary internal-combustion engine. US Patent No. 1,095,034 A, 29 Outubro 1912, 28 Abril 1914.

SARICH, T. R. An improved rotary motor. US Patent No. Re.29230, 6 Julho 1970, 14 Novembro 1975.

SCHÖNROCK, M. RotaTorque. Disponivel em: <http://www.rotatorque.de/entwicklungen/rotationsmotor/>. Acesso em: 24 jun. 2016.

SHEEHAN, S. autocar.co.uk, 29 abril 2016. Disponivel em: <http://www.autocar.co.uk/car-news/industry/volkswagen-launches-newmodular-petrol-engines>. Acesso em: 19 set. 2016. 
SHERMAN, D. automobilemag, 10 mar. 2008. Disponivel em: $<$ http://www.automobilemag.com/news/mazda-the-rotary-club/>. Acesso em: 26 jun. 2016.

SHIMIZU, R. et al. Rotary Piston Engine mounted on Vehicle. US Patent N. 0084158 A1, 12 Agosto 2015, 24 Março 2016.

TAUROZZI, E. Rotary Engine. US Patent No. 3,854,457, 6 Outubro 1972, 17 Dezembro 1974.

TICONA, E. M.; GUARATO, A. Z.; BRAGA, S. L. Mathematical modeling and analysis of thermodynamic processes of an irreversible miller cycle working on a piston rotary engine In. 23rdABCM International Congress of Mechanical Engineering. Rio de Janeiro, Brasil: [s.n.]. 2015. p. 7.

TSCHUDI, T. Rotary Internal Combustion Engine. US Patent No. 3,381,669 A, 31 Outubro 1966, 7 Maio 1968.

UMPLEBY, F. Improvements in an relating to Rotary Internal Combustion Engines. UK Patent No. 24,559 A, 16 Novembro 1908.

WANKEL, F. Rotary piston machines. [S.I.]: LONDON ILIFFE BOOKS LTD, 1965. 64 p. Título original: Einteilung der Rotations-Kolbenmaschinen. WERNER, E. H. Rotary Engine. US Patent No. 716,970 A, 26 Maio 1902, 30 Dezembro 1902.

WITTRY, D. B. Rotary Engine with variable compression ratio. US Patent No. 5,433,179 A, 2 Dezembro 1993 , 18 Julho 1995.

YAMAMOTO, K. Rotary Engine. 1. ed. [S.I.]: TOKYO KOGYO CO., LTD, 1969.

ZOU, T. A. et al. Mathematical modeling and analysis of thermodynamic processes in a twin-rotor piston engine. Journal of Central South University, v. 21, n. 11, p. 4163-4171, 15 Novembro 2014. 